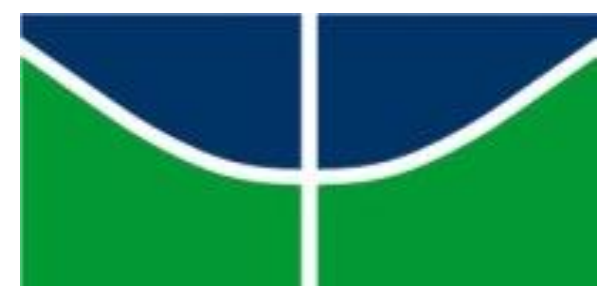

UNIVERSIDADE DE BRASÍLIA

FACULDADE DE EDUCAÇÃO

PROGRAMA DE PÓS-GRADUAÇÃO EM EDUCAÇÃO

\title{
IDENTIFICAÇÃO E FORMAÇÃO DE VALORES PESSOAIS NO AMBIENTE ESCOLAR DE ENSINO FUNDAMENTAL II: O SUJEITO ECOLÓGICO EM CONSTRUÇÃO
}

LUIZ GONZAGA LAPA JUNIOR 


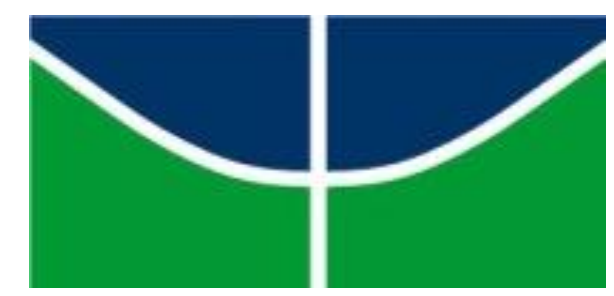

UNIVERSIDADE DE BRASÍLIA

FACULDADE DE EDUCAC̄̃̃O

PROGRAMA DE PÓS-GRADUAÇÃO EM EDUCAÇÃO

\section{IDENTIFICAÇÃO E FORMAÇÃO DE VALORES PESSOAIS NO AMBIENTE ESCOLAR DE ENSINO FUNDAMENTAL II: O SUJEITO ECOLÓGICO EM CONSTRUÇÃO}

LUIZ GONZAGA LAPA JUNIOR

Dissertação de Mestrado apresentada ao Programa de Pós-Graduação em Educação na Faculdade de Educação da Universidade de Brasília/UNB, como parte dos requisitos para obtenção do título de Mestre em Educação sob a orientação da Prof ${ }^{a}$ Dra ${ }^{a}$. Claudia Márcia Lyra Pato. 
LAPA JR., Luiz Gonzaga - 1961

Identificação e formação de valores pessoais no ambiente escolar de ensino fundamental II: O sujeito ecológico em construção / Luiz Gonzaga Lapa Junior. 2014.

Orientadora: Claudia Pato

Dissertação de Mestrado - Universidade de Brasília, Faculdade de Educação, Programa de Pós Graduação, 2014.

Referências Bibliográficas: f. 104 - 114.

1. Educação Ambiental. 2. Ecologia Humana. 3. Valores Humanos. 4. Valores Ecológicos. 5. Intervenções Pedagógicas - Oficinas. I. Pato, Cláudia Márcia Lyra. II. Universidade de Brasília. Faculdade de Educação. Programa de PósGraduação em Educação. III. Título. 


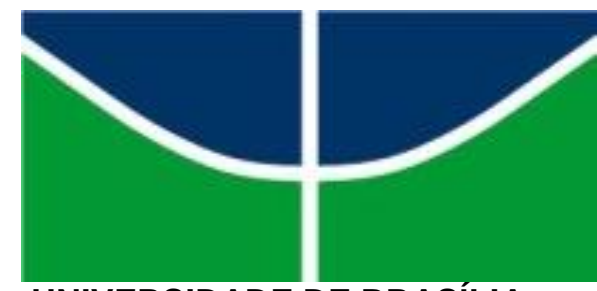

UNIVERSIDADE DE BRASÍLIA

FACULDADE DE EDUCAÇÃO

PROGRAMA DE PÓS-GRADUAÇÃO EM EDUCAÇÃO

Dissertação de Mestrado

\title{
IDENTIFICAÇÃO E FORMAÇÃO DE VALORES PESSOAIS NO AMBIENTE ESCOLAR DE ENSINO FUNDAMENTAL II: O SUJEITO ECOLÓGICO EM CONSTRUÇÃO
}

\author{
Orientadora \\ Professora Doutora Claudia Márcia Lyra Pato \\ BANCA EXAMINADORA: \\ Professora Doutora CLAUDIA MÁRCIA LYRA PATO \\ Presidente \\ Professora PhD MARIA INÊS GASPARETTO HIGUCHI \\ Instituto Nacional de Pesquisas da Amazônia / INPA \\ Laboratório de Psicologia e Educação Ambiental / LAPSEA
}

Professor Doutor PHILIPPE POMIER LAYRARGUES

Universidade de Brasília / Faculdade de Planaltina

Professora Doutora VERA MARGARIDA LESSA CATALÃO Universidade de Brasília / Faculdade de Educação Suplente 


\section{DEDICATÓRIA}

Ao meu pai, que nunca deixou de estar ao meu lado, foi meu professor, meu amigo, meu "espelho", meu "livro", dedico este trabalho como seu fã incondicional como exemplo de homem, educador e cidadão; à minha mãe que sempre me mostrou o sentido de amar a vida; à minha esposa que sempre esteve ao meu lado com palavras de incentivo e aos meus filhos que são dádivas de Deus. 


\section{AGRADECIMENTOS}

À minha esposa pelos momentos de paciência e compreensão.

À minha mãe pela confiança e por acreditar num crescimento intelectual e espiritual.

À minha orientadora Claudia Pato pelos "olhares divinos", pela atenção, paciência, sabedoria, confiança, cumplicidade e "leituras" dos pensamentos .......

À minha mãe Giramundo, meu padrinho Boiadeiro, aos meus amigos Filé, Irmão José, Pinote, Pai Januário e todas as Entidades que estiveram sempre presentes e continuam me acompanhando.

À toda Direção e professores do Centro de Ensino Fundamental Miguel Arcanjo por acreditarem neste trabalho e abrirem as portas e janelas para que a pesquisa fosse realizada.

Aos meus queridos amigos e amigas de junção do Centro Espírita Lar dos Amigos, Joaquim, Lica, Joãozinho, Verani, Lúcia, Pâmela, Luciano, Luana, Divina, Doroteu e muitos outros, que formaram uma grande corrente de amor.

À todo o corpo docente da Faculdade de Educação da Universidade de Brasília que compartilharam conhecimentos.

À Sandra Pereira Couto Cabral que foi o "anjo" quem me fez despertar para a Educação Ambiental e conviver com os olhares divinos da prof ${ }^{a}$. Claudia Pato.

À minha irmã e afilhada Isabela pelo seu amor e compreensão pelas minhas ausências em família e nos churrascos programados.

À todo(a)s o(a)s amigo(a)s e conhecido(a)s pelas palavras de incentivo e motivação quando souberam desse meu desafio.

E, propositadamente nesta posição, agradeço a DEUS por mais esta oportunidade, pois Ele é quem providenciou com que todos estes fizessem parte da minha caminhada. 


\section{RESUMO}

O ambiente escolar, visto como microssistema de um sistema social maior, tem sido cada vez mais palco de conflitos e danos pessoais e materiais, refletindo uma crise de valores nas relações e inter-relações. Sendo a escola uma das principais instituições sociais responsáveis pela formação do cidadão, o que implica em formação e transmissão de valores para uma vida em sociedade, espera-se que as novas gerações de estudantes sejam capazes de lidar com os conflitos e respeitar as normas para uma convivência social sustentável. Entretanto, a escalada da violência em suas diversas manifestações (pessoal, ambiental e simbólica), sobretudo no ambiente escolar da instituição pública, revela uma contradição que sugere a omissão ou ineficácia da escola no cumprimento de seu papel. Considerando-se a centralidade dos valores no sistema pessoal e sociocultural, a educação formal deve assumir sua corresponsabilidade e atuar de forma efetiva para a formação humana em seus aspectos éticos e morais. Dessa forma, espera-se contribuir para que os estudantes sejam capazes de atuar e viver em sociedade de maneira sensível, crítica, criativa e sustentável. Este trabalho investigou os valores pessoais de estudantes do ensino fundamental II em uma escola pública do Distrito Federal e promoveu intervenções pedagógicas por meio de oficinas, com uso de dinâmicas cooperativas. Na primeira etapa, foi realizado um survey com todos os estudantes da escola $(N=980 ; 51,2 \%$ meninas; média de idade $=13,04)$ para identificar os valores pessoais e verificar as turmas que possuíam menos valores de autotranscendência, conforme Schwartz (2005). Na segunda etapa, foram realizadas oficinas pedagógicas centradas na formação de valores. Participaram dessa etapa 70 estudantes das duas turmas que apresentaram menores médias de valores de autotranscendência: uma do turno matutino e outra do vespertino (55,6\% meninas; média de idade $=13$ ). As análises de escalonamento multidimensional (EMD) revelaram que os valores pessoais dos estudantes possuíam estruturas semelhantes ao do modelo teórico de Schwartz. No processo de intervenção foi possível observar que os estudantes demonstraram interesse nas atividades, expressaram comportamentos mais afetuosos, respeitosos e solidários entre eles e com os professores, e destacaram a importância desse tipo de trabalho na formação deles, entre outros. Após as oficinas foi realizado novo survey com as duas turmas que participaram do processo de formação para comparação com os valores que os estudantes tinham antes desse processo. Os resultados indicaram uma tendência de aumento na média dos valores de autotranscendência para as duas turmas, revelando preocupação maior com o bem-estar de si mesmos, dos outros e do ambiente de convivência e relações. Estes resultados demonstram que a formação de valores pessoais de forma dinâmica, vivencial e simbólica contribui para a mudança nos comportamentos dos estudantes e para a promoção de um ambiente mais ecológico e sustentável. Isso pode favorecer a resolução de conflitos e a reversão do cenário atual tanto no ambiente escolar quanto fora dele.

Palavras-chave: valores pessoais, formação de valores, formação do sujeito ecológico, educação ambiental. 


\begin{abstract}
The school environment, seen as microsystem of a larger social system, has increasingly been the scene of conflict and injury or damage, reflecting a crisis of values in relationships and interrelationships. As the school one of the main social institutions responsible for the training of citizens, which implies formation and transmission of values to a life in society, it is expected that new generations of students are able to deal with conflicts and the rules for sustainable social life. However, the escalation of violence in its various forms (personal, environmental and symbolic), particularly in the school environment of a public body, reveals a contradiction that suggests the omission or school ineffective in fulfilling its role. Considering the centrality of values in personal and socio-cultural system, formal education must assume its responsibility and act effectively to human development in its ethical and moral aspects. Thus, it is expected to contribute to that students are able to work and live in society in a sensitive manner, critical, creative and sustainable. This study investigated the personal values of elementary school students II in a public school in the Federal District and pedagogical interventions promoted through workshops, using dynamic cooperatives. In the first step, we conducted a survey of all school students ( $\mathrm{N}=980 ; 51.2 \%$ female; mean age = 13.04) to identify personal values and check the courses that had less selftranscendence values as Schwartz (2005). In the second stage, educational workshops focused on the formation of values were performed. Participated in this stage 70 students from two classes that had the lowest average self-transcendence values: a morning shift and one of the evening (55.6\% girls; medical age $=13)$. The multidimensional scaling analysis (SSA) revealed that the personal values of the students had similar structures to the theoretical model of Schwartz. The intervention process was observed that the students showed an interest in the activities, behaviors expressed more affectionate, respectful and solidarity among themselves and with the teachers, and stressed the importance of this type of work in training them, among others. After the workshops we carried out another survey with two groups who participated in the training process for comparison with the values that the students had prior to this process. The results indicated an increasing trend in the average of self-transcendence values for the two groups showing more concern for the well-being of themselves, others and the coexistence and relations environment. These results demonstrate that the formation of personal values dynamically, experiential and symbolic contributes to the change in the behavior of students and to promote a greener and sustainable environment. This can facilitate the resolution of conflicts and the reversal of the current situation both at school and outside it.
\end{abstract}

Keywords: personal values, values formation, formation of ecological subject, environmental education. 


\section{LISTA DE ILUSTRAÇÕES}

Figura 1- Mapa do EMD (I) dos tipos motivacionais de todos os estudantes da escola

Figura 2 - turma do 6‥L entrevistas entre os sujeitos

Figura 3- Turma $8^{\circ} . \mathrm{D}$ na $5^{\mathrm{a}}$. IPO

66

Figura 4 - Turma $8^{\circ}$.D na dinâmica dos quadrados 66

Figura 5 - turma do $8^{\circ} . \mathrm{D}$ na $6^{\mathrm{a}}$. IPO

Figura 6 - turma do $6^{\circ}$. L na $7^{\text {a }}$. IPO 68

Figura 7 - Turma $8^{\circ}$. D na 9a. IPO. 79

Figura 8 - turma do $6^{\circ}$. L na 9a . IPO 79

Figura 9 - O desafio do Pulo Gigante ( turma do 6ํ․) 80

Figura 10 - Mapa do EMD (II) após o término das IPO e aplicação do $2^{\circ}$ questionário 90

Figura 11 - Grau de dispersão dos desvios padrão encontrados no EMD(II) 93 


\section{LISTA DE GRÁFICOS}

Gráfico 1: Freqüência dos sujeitos aos cultos religiosos............................... 45 


\section{LISTA DE QUADROS}

Quadro1 - Valores Humanos - Tipos motivacionais de Schwartz. Fonte: Bilsky (2009)

Quadro 2 -Modelo dos 10 tipos de valores motivacionais de Schwartz ......... 36

Quadro 3 - Valores associados aos 10 tipos motivacionais .......................... 37

Quadro 4 - Comparativo de valores percebidos e sentidos pelos alunos, conforme questões abertas

Quadro 5 - Informativo das 05 categorias de valores, para análise qualitativa $\quad 60$

Quadro 6 - Percepção dos alunos sobre os colegas, durante a 1‥ IPO ......... 62

Quadro 7 - Problemas/conflitos registrados na 14ㄹ. IPO ................................ 69

Quadro 8 - Reflexões dos sujeitos na 11ạ. IPO............................................ 73

Quadro 9 - Subcategorias dos dados levantados na 3a. IPO - qualidades dos sujeitos

Quadro 10 - Quantitativo das ocorrências das qualidades citadasna 3리O .. $\quad 77$

Quadro 11 - Médias e os desvios padrão dos itens do $2^{\circ}$ questionário ........... 92 


\section{LISTA DE TABELAS}

Tabela 1 -Características da população ................................................ 43

Tabela 2-Características dos participantes da pesquisa ............................ 44

Tabela 3 - Médias da dimensão autotranscendência do $1^{\circ}$ questionário........... 50

Tabela 4 - Médias e Moda de todos os estudantes da escola 1questionário

Tabela 5 - Médias das dimensões dos tipos motivacionais- todos os alunos da escola

Tabela 6 - Valores transmitidos pelos professores durante suas aulas, conforme o $8^{\circ} . \mathrm{D}$ e $6^{\circ}$.L.

Tabela 7 - Valores que os alunos do 8으 e 6느 consideram importantes para se viver bem hoje

Tabela 8 - Médias e Moda dos sujeitos participantes ANTES e DEPOIS das IPO - 6느 e 8D

Tabela 9 - Médias nas dimensõesdos sujeitos da amostra ANTES e DEPOIS das IPO

Tabela 10 - Desvio padrão das dimensões no $2^{2}$.questionário 


\section{LISTA DE SIGLAS}

\begin{tabular}{|c|c|}
\hline IPO : & Intervenções Pedagógicas - Oficinas \\
\hline Md : & Média aritmética \\
\hline LDB & Lei de Diretrizes e Bases da Educação Nacional \\
\hline PCN & Parâmetros Curriculares Nacionais \\
\hline EMD (I) & $\begin{array}{l}\text { 19 Mapa de Escalonamento Multidimensional - todos os } \\
\text { alunos da escola }\end{array}$ \\
\hline EMD (II) & $\begin{array}{l}2^{\circ} \text { Mapa de Escalonamento Multidimensional - os alunos } \\
\text { participantes das intervenções pedagógicas }\end{array}$ \\
\hline PQ21 & $\begin{array}{l}\text { Portrait Questionaire - Perfil de Valores Pessoais de } \\
\text { Schwatrz com } 21 \text { itens }\end{array}$ \\
\hline MDS & $\begin{array}{l}\text { Escalonamento Multidimensional (Smallest Space } \\
\text { Analysis-SSA). }\end{array}$ \\
\hline
\end{tabular}




\section{SUMÁRIO}

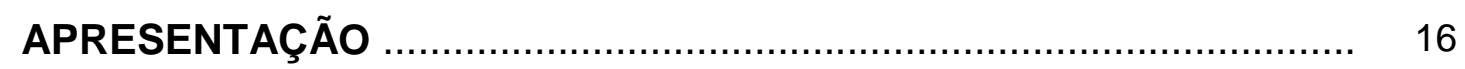

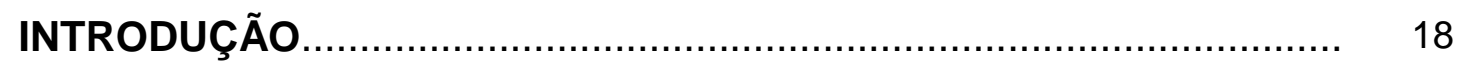

Capítulo 1. O AMBIENTE ESCOLAR COMO ESPAÇO DE RELAÇÕES E INTER- RELAÇÕES. CENÁRIO ATUAL DA ESCOLA .... 22 Educação Ambiental e Ecologia Humana ................................... 25

1.1.

1.2. A formação do sujeito ecológico na perspectiva da ecologia humana

Capítulo 2. VALORES HUMANOS E EDUCAÇÃO …........................... 32

2.1. Teoria de Valores Humanos de Schwartz ................................. 35

2.1.1. Outros olhares para valores ................................................ 37

2.2. Valores ecológicos ……....................................................... 40

Capítulo 3. O MÉTODO_.................................................................. 42

3.1. Os participantes ............................................................... 42

3.1.1. Caracterização dos participantes do survey ............................. 43

3.1.2. Caracterização dos participantes da intervenção pedagógica .... 44

3.2.. As estratégias da pesquisa ............................................... 45

3.3. Os instrumentosutilizados .................................................. 46

3.4. Os procedimentos................................................................. 47

3.5. As análises dos dados ...................................................... 48

Capítulo 4. OS RESULTADOS .......................................................... 50

4.1. Valores e médias dos estudantes de toda a escola .................... 50

4.1.1. O panoramados estudantes da escola no Mapa do EMD....... 54

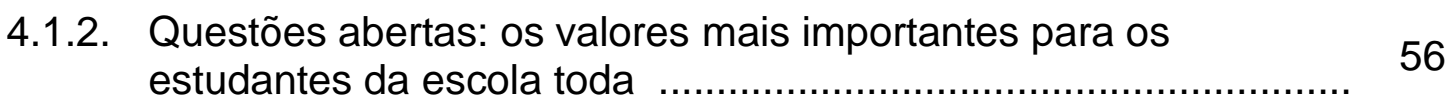


4.2. A trajetória das intervenções pedagógicas-oficinas- IPO .......... 59

4.3. Pós-IPO: os valores pessoais dos participantes da pesquisa ...... 87

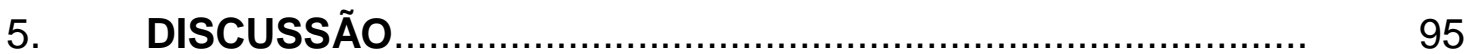

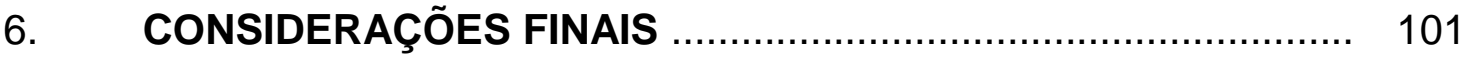

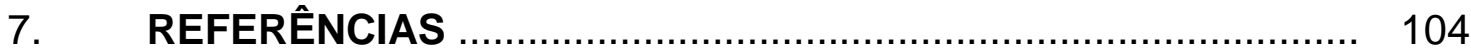

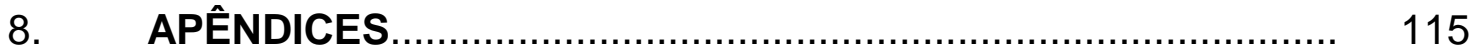

Apêndice A - Questionário PQ21 ……........................................... 115

Apêndice B - Formulário de informações ........................................... 120

Apêndice C - Folha aplicada na dinâmica da 1a..IPO ............................ 121

Apêndice D - Folha de perguntas aplicada na $2^{\mathrm{a}} . \mathrm{IPO}$........................... 122

Apêndice E - Folha aplicada na 14a..IPO ............................................ 123

Apêndice F - Folha aplicada na 3…IPO ........................................... 124

Apêndice G - Folha aplicada na 4a .IPO ....................................... 125

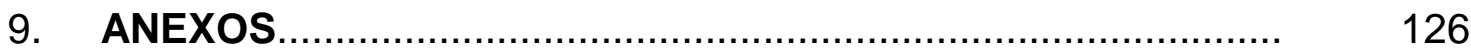

Anexo 1 - Consentimentoda S.E.E.D.F. ............................ 126

Anexo 2 - Permissão ao C.E.F. Miguel Arcanjo ........................ 127

Anexo 3 - Consentimento do C.E.F. Miguel Arcanjo $\ldots \ldots \ldots \ldots \ldots \ldots \ldots . . . \ldots \ldots$ 


\section{APRESENTAÇÃO}

Sou filho de professor de matemática e filosofia, e meu pai tinha prazer em ensinar, tratando a Educação Matemática com ludicidade, leveza e compromisso, sendo este o motivo de inspiração paraminha escolha profissional graduação em Matemática. Ele foimeu professor na faculdade, amigo e exemplo de profissional. Dessa forma tento seguir seus passos no trato humanitário e amoroso com os estudantes.

Atuei em várias escolas das redes pública e particular do Distrito Federal com experiência no ensino superior e gestão escolar. Atualmente, na escola em que me encontro, utilizei nas aulas de Matemática jogos de raciocínio, atividades lúdicas com materiais concretos, vídeos ilustrativos, e vários momentos de conversas a respeito de temas/assuntos que surgiram com a curiosidade dos estudantes gravidez, preservativos, consumo de drogas, assassinatos na cidade, furtos, violência doméstica, sexo na adolescência, homossexualismo, respeito a mulher, hábitos de colocar o lixo fora das lixeiras e saber esperar a vez de falar - na tentativa de estreitar os relacionamentos interpessoais desses estudantes, e manter as relações entre professor e estudantes de forma amistosa, mesmo assim, continuavam a conversar gritando, a ofender gratuitamente seus pares, a jogar papel de doces no chão, a sair para os intervalos das aulas com desrespeito aos colegas. O que fazer neste quadro de aparente desolação?

Aproveitando-se da reciprocidade dos estudantes nos momentos de conversas descontraídas, com muita atenção e participação, foram realizadas campanhas de recolhimento de garrafas pets, caixas de leite e sucos tipo tetra pak, entre outros vasilhames de plásticos, com o objetivo de arrecadar recursos financeiros para a compra de ventiladores para as salas de aula. Surpresa foi constatar o engajamento de boa parte desses estudantes preocupados em ter salas menos aquecidas.

Com tanto material recolhido, professores e estudantes confeccionaram jogos e ferramentas didáticas, e provocaram reflexões sobre os cuidados com restos de materiais que poderiam ser reutilizados e sobre 0 ato da reciclagem. Surgiram outros estudantes que construíram "engenhocas" com sucata e "lixo" caseiros, porém, mesmo com este olhar cuidadoso para este contexto ambiental, poucos 
eram os momentos de harmonia nas salas de aula, faltava-lhes respeito, solidariedade, cooperação e ajuda mútua no convívio diário. Algo precisara ser feito para formar determinados valores nesses estudantes dando-lhes sentido de cidadania e autonomia em suas ações e decisões. A partir daí, meu desejo foi focado em como trabalhar para despertar a sensibilidade, o olhar e a preocupação desses estudantes para 0 ambiente a sua volta, em suas dimensões socioambientais e relacionais, de modo a contribuir para a formação de um sujeito ecológico.

Estadissertação procurou encontrar meios para minimizar as conturbadas relações interpessoais entre os estudantes, trabalhando com a formação de valores humanos através de intervenções pedagógicas, por meio de oficinas, com o uso de dinâmicas cooperativas, na perspectiva de mudanças em seus comportamentos, para a promoção de um ambiente escolar mais ecológico e harmonioso, possibilitando transformações no cenário atual da comunidade escolar. Para tanto, encontrei na Educação Ambiental e Ecologia Humana o entendimento do "o que poderia ser feito", ficando a investigação do "o como fazer" a cargo desta pesquisa. 


\section{INTRODUÇÃO}

Os conceitos de cidadania e autonomia são relacionados a termos estratégicos para a construção de uma sociedade melhor (GADOTTI, 1998a) no qual a escola promove espaços privilegiados para esta aprendizagem. Cidadania é uma palavra com vários sentidos, porém, em essência, significa o direito de viver bem, de fazer escolhas (DIMENSTEIN, 1998) onde implica que instituições como a escola, no qual a autonomia faz parte da própria natureza da educação e que carrega promessas de mobilidade social (GADOTTI e ROMÃO, 1998b; apud GADOTTI, 2010), contribuam para a transformação social do indivíduo/estudante, conseqüentemente, isto se reflete nas relações interpessoais entre os entes da comunidade escolar - estudantes, professores, direção, coordenação, servidores em geral.

Para que as pessoas, em particular os estudantes, tenham um desenvolvimento contínuo e mais harmonioso, a educação surge como um trunfo indispensável à humanidade na sua construção dos ideais da paz, da liberdade e da justiça social, visando reduzir a pobreza; a exclusão social; as incompreensões; as opressões; num um processo permanente de enriquecimento de conhecimentos, como uma via privilegiada de construção da própria pessoa, das relações entre indivíduos, grupos e nações (DELORS, et al, 2010). A educação defendida e tratada neste trabalho é promovida, principalmente, em instituições como a escola, pois, a comunidade pesquisada é desprovida de outras vias, na prestação do serviço da transmissão de valores autotranscendentes para uma vida em sociedade.

O desejo de uma transformação social nos estudantes (crianças/adolescentes) visa conscientizá-los de seus atos consigo e com os outros, promovendo melhorias das condições de vida, criar condições favoráveis à preservação ambiental, praticar o respeito ao próximo, para formar sujeitos ecológicos, dando-lhesconhecimento e vivência. É tarefa da escola, fomentar ações educativas para a construção dessa cidadania e autonomia. Porém, percebemos que muitas escolas têm passado por transformações contrárias a esse ideário, ocupando-se fundamentalmente com o ensino de conteúdos fragmentados, desligadas de seu contexto, cheia de contradições, exigências de adaptações e 
ausência de significados positivos para a vida escolar (OTT, 1983; SPOSITO, 1998, 2008; AQUINO, 1998; DAYRELL, 2009, ABBUD, 2010). Este panorama, além de outros fatores, é produto das ações de muitos professores que permanecem com práticas educativas mais conservadoras do que inovadoras ou renovadoras (AQUINO, 2010), contribuindo para um ensino desmotivador, fortalecendo rupturas nas relações interpessoais dos estudantes na escola.

Essas relações conturbadas podem ser provenientes de crises de valores nos estudantes, sugerindo que a escola esteja se omitindo do seu papel de cuidar das futuras gerações como uma das principais instituições responsáveis pela formação do cidadão, sendo capazes de lidar com os conflitos pessoais, respeitando normas e regras de convivência numa vida em sociedade. Neste olhar, a educação formal deve atuar de forma efetiva para a formação humana em seus aspectos éticos e morais, implicando na transmissão de valores de autotranscendência.

A escola com uma educação com base em valores humanos ecológicos (autotranscendência) pode preparar os estudantes a fazer suas próprias escolhas e tomar decisões com autonomia, sendo capazes de conviver com a diversidade e de participar de questões relacionadas ao bem comum, permitindo compreender o mundo que os rodeia e comportar-se nele de forma responsável e justa. Da mesma forma, pode contribuir para a mudança de atitudes e comportamentos dentro e fora da escola. Nesse contexto a educação pode ser considerada a chave que abre as portas do século XXI. Para Vieira e Sforni (2008), tanto o Relatório Jacques Delors, quanto os PCNs atribuem à escola "a formação de um indivíduo capaz de atuar com competência e dignidade na sociedade em que vive e de interferir criticamente na realidade para transformá-la" (p. 6).

Uma escola com responsabilidade individual e coletiva, num processo de aprendizagem permanente baseado no respeito a tudo e a todos, deve reconhecer o papel central da educação na formação de valores e na ação social, para criar sociedades sustentáveis e eqüitativas, visando a transformação humana para a preservação ecológica (PRONEA, 2003).

A motivação para a investigação dessas relações interpessoais na escola e o interesse naformação de valores autotranscendentes nos estudantes teve como 
eixo orientador a Ecologia Humana, que conforme Dansa, Pato e Corrêa (2014), é um campo aberto e multirreferencial, que resulta na compreensão de como podemos ser conhecedores de nós mesmos e do mundo, possibilitando transformar nosso convívio no mundo, auxiliando na construção "de um processo educativo que possibilite ao sujeito individual e coletivo refazer o seu fazer, a partir da ampliação do seu próprio ponto de vista de uma forma mais complexa, criativa, integral e dialógica" (p. 02).

A respeito dos diversos caminhos metodológicos para práticas educativas, Catalão, Mourão e Pato (2009) relatam que a Ecologia Humana e Educação Ambiental contribuem "à pesquisa científica sobre conhecimentos, valores e vivências que influenciam a construção do sujeito ecológico, percepção ambiental, crise e sustentabilidade, e sobre a escola como espaço socioambiental de construção do conhecimento e produção de sentidos" (p.30).

Conforme o olhar das autoras a Ecologia Humana tem a perspectiva em poder promover a construção de sujeitos ecológicos. Nessa vertente e cuja preocupação primeira foi a busca pelo bem-estar de estudantes, respeitando a si e aos demais colegas da escola, priorizando práticas coletivas de ajudas mútuas com vivências de solidariedade e cooperação. A formação em valores, com foco nos ecológicos (Pato, 2011b) e de autotranscendência (Schwartz, 2005), pode contribuir para a mudança de atitudes e comportamentos, entre outros, visando à construção de relações mais sustentáveis. Do mesmo modo, favorecer a resolução de conflitos e a proteção socioambiental.

A importância em se trabalhar na formação de valores é recomendada pela LDB (1996) quando aponta a educação em valores como principal objetivo do ensino fundamental (art. ${ }^{32^{\circ}}$ ) para a compreensão do ambiente natural e social, das artes e dos valores em que se fundamentam a sociedade (inciso II); O desenvolvimento da capacidade de aprendizagem com vistas a aquisição de conhecimentos e a formação de atitudes e valores (inciso III) e o fortalecimento dos vínculos de família, dos laços de solidariedade humana e de tolerância recíproca em que se assenta a vida social (inciso IV). 
Da mesma forma os PCN (1997a) explicitam os valores com diversos olhares: como orientadores do trabalho pedagógico nas escolas; como valores sociais acumulados pelas gerações passadas; a formação de valores e atitudes do sujeito em relação ao outro e ao meio ambiente; os valores coletivos assumidos nos projetos educativos, implícitos e explícitos que permeiam as relações entre os membros da escola; os valores mais gerais e unificadores tratados nos temas transversais e na ação pedagógica; e uma ressignificação da noção de conteúdo passando a incluir valores, normas e atitudes como conteúdos escolares para melhorias no relacionamento entre as pessoas visando o aprender a conviver em grupo.

Diante do desejo em contribuir para a construção de conhecimento na temática e com o intuito de promover discussões e reflexões nas práticas docentes servindo de projeto orientador nas escolas, o objetivo deste trabalho foi identificar os valores pessoais de estudantes do ensino fundamental de uma escola pública do Distrito Federal e desenvolver um processo de formação em valores, com ênfase nos de autotranscendência, tendo em vista a construção de sujeitos ecológicos na perspectiva da ecologia humana.

Desta forma, o Capítulo 1 objetiva relatar o ambiente escolar como local para as relações e inter-relações entre os estudantes e explicar o panorama da escola pesquisada para compreender os valores adquiridos. O Capítulo 2 abarca as discussões teóricas que dão alicerce à teoria dos valores humanos e ecológicos. No Capítulo 3 são descritos os procedimentos metodológicos que orientaram para a investigação do objeto de estudo. O Capítulo 4 descreve os resultados da pesquisa, complementando com as discussões e considerações finais, que compõem com contribuições sobre o desenvolvimento de um processo de formação de valores, e encerrando com as referências que deram aporte ao trabalho. 


\section{Capítulo 1. O AMBIENTE ESCOLAR COMO ESPAÇO DE RELAÇÕES E INTER-RELAÇÕES. CENÁRIO ATUAL DA ESCOLA.}

Este trabalho teve o propósito de pesquisar os valores de um grupo de estudantes para compreender suas relações em sala de aula, mediante um quadro de conflitos pela ausência de uma convivência harmoniosa e a falta de respeito entre seus pares. Sendo os valores antecedentes dos comportamentos, conhecendo-os pode-se investigar e compreender os modos de agir (PATO e TAMAYO, 2002) desse grupo de estudantes, visando uma formação em valores autotranscendentes, possibilitando mudanças em suas condutas, levando-os a um comportamento ecológico, contribuindo para práticas e ações de proteção ao meio ambiente, particularmente, o escolar. Para Pato (2011a), "comportamento ecológico é a ação humana que visa contribuir para proteger o meio ambiente ou para minimizar o impacto ambiental de outras atividades." (p. 122)

Encontramos na literatura algumas denominações significantes e sinônimas do conceito de comportamento ecológico, sendo um deles, como o conjunto de ações intencionais voltadas ao convívio social e individual para proteger o meio ambiente; ou são relações com o não desperdício dos recursos naturais preocupados com as gerações futuras; ou são formas de relacionamentos entre o ambiente e o contexto cultural das pessoas, sendo incorporadas em suas rotinas (CORRAL-VERDUGO, 2001; CARVALHO, 1998; CORRALIZA E BERENGUER, 2000 apud PATO, 2011a).

Quaisquer que sejam os conceitos relativos ao comportamento ecológico, particularmente no ambiente escolar, estes permeiam por condutas positivas que levam as pessoas a viverem melhor; respeitando seus próximos; os cuidados com os ambientes frequentados, sendo atentos às ajudas individuais que corroboram com o coletivo sem que se percebam, em curto prazo, o benefício causado, como é o caso de apagar as luzes ao sair de uma sala de aula.

Este é um ideário a ser alcançado na escola, porém, para compreender essas situações de conflito, necessitamos conhecer o ambiente escolar como espaço para as diversas relações. 
Na escola, fala-se muito em "qualidade de ensino", porém, Gadotti (2013) explica que "qualidade" significa melhorar a vida de todas as pessoas e que uma escola deve ser de qualidade sociocultural, contendo uma formação para a cidadania e não apenas a transmissão de conteúdos. O autor explica que nesse novo espaço de formação tornar-se fundamental "saber comunicar-se, saber pesquisar, saber fazer, ter raciocínio lógico, aprender a trabalhar colaborativamente, fazer sínteses e elaborações teóricas, saber organizar o próprio trabalho, ter disciplina, ser sujeito da construção do conhecimento, estar aberto a novas aprendizagens, conhecer as fontes de informação, saber articular o conhecimento com a prática e com outros saberes" (GADOTTI, 2013, p. 8).

Neste sentido, a escola cria novas relações sociais e humanas, deixando de ser "lecionadora para ser cada vez mais gestora da informação generalizada, construtora e reconstrutora de saberes e conhecimentos socialmente significativos" (GADOTTI, 2013, p. 9). Torna-se necessário educar com novos valores, ou conforme Gadotti (2013), educar para uma vida sustentável, com responsabilidades compartilhadas, praticando a sustentabilidade no dia-a-dia, dentro e fora da escola, com ações mais cooperativas, coletivas do que as individualistas.

$\mathrm{Na}$ realidade, muitas escolas passam por uma frágil e conturbada relação existente entre seus estudantes, podendo se configurar como um quadro iminente de violência escolar. Para Abramovay (2004) o impacto dessas situações de violências é a transformação do clima escolar e o enfraquecimento das relações incidindo sobre a qualidade das aulas e o desempenho dos estudantes. A comunidade escolar estudada neste trabalho pratica atos que desorganizam o cotidiano da sala de aula, impondo uma indisciplina que ultrapassam os limites das condutas socialmente esperadas em nome da boa convivência, como agressões verbais entre os estudantes, depredações ao patrimônio público, desrespeito às regras e normas escolares e falta de respeito entre os entes da escola - estudantes, professores, direção e funcionários em geral. Esse "clima de desordem" também incide sobre a percepção dos estudantes a respeito do espaço físico da escola, transformando em um ambiente desfavorável às melhorias das relações entre os sujeitos da escola(ABRAMOVAY, 2004). 
Se muitas vezes a escola torna-se um ambiente antagônico às boas relações, quais valores estariam incorporados às mentes e ações dos estudantes? Que ações e motivos seriam propulsores dessa má convivência entre os estudantes? Para Schwartz (2005) os valores das pessoas justificam suas ações e são importantes para compreender o pensamento humano, além de influenciar o seu comportamento, "em especial quando o comportamento implica em conflitos de valores" (p.18). Motivo pelo qual este trabalho procurou identificar os valores de estudantes para compreender suas relações conflituosas e realizar intervenções pedagógicas visando à formação de valores de autotranscendência.

Pesquisa feita sobre o tema "Indisciplina e violência da/na escola e juventude" indicou que, da última década para os dias atuais, houve um deslocamento do protagonismo da violência escolar que teria passado dos grupos externos à escola para os próprios estudantes e que esses incidentes passaram a se concentrar no período das aulas (DAYRELL, 2009). As interrogações se voltam para a identificação de quais valores estariam sendo prioritários no cotidiano dos estudantes. Dayrell (2009) explica que muitos trabalhos de pesquisa evidenciam em suas conclusões que a violência escolar "é expressão de uma crise da instituição escolar" (p. 68), explicada pordiferentes argumentos. Para o autor uns trabalhos apontam que existe uma crise de identidade pela qual passa a escola como um todo, especificamente, na relação professor-aluno; outros direcionam que a crise é resultado da homogeneização escolar, ou seja, a escola não leva em consideração as especificidades sócio-culturais dos estudantes; outros trabalhos orientam que esta crise está ligada às relações entre os estudantes e o modelo escolar vigente. A comunidade escolar pesquisada possui uma mescla dessas evidencias tornando difícil as relações entre seus pares.

Ao longo dos anos, essa crise reduziu a educação a um processo de mera reprodução dos conhecimentos, exercitando a instrução mecânica dos estudantes em relação aos conteúdos e, com isso, todo o processo de formação do ser humano tem sido negligenciado (VOLPATO, 2010), contrariando as expectativas de Gadotti para a formação de um ambiente escolar mais sustentável. Neste sentido os estudantes têm demonstrado pouco interesse nesta forma de ensino, indicando insatisfação, revolta, impaciência, desestímulo, baixa estima, desprazer pelo 
ambiente, deixando que outras prioridades se instalem no cotidiano escolar. Os estudantes da escola trabalhada apresentam um comportamento de desinteresse pelo processo educacional posto no cotidiano, incluindo o comportamento ecológico, que de acordo com Pato (2011a) a compreensão do que seja comportamento ecológico permite estabelecer estratégias de intervenção mais eficazes para melhorias na qualidade de vida de todos e de tudo. Esta ação corresponde a um dos objetivos específicos desta pesquisa: a de testar a hipótese de que intervenções pedagógicas, por meio de oficinas, utilizando dinâmicas cooperativas, contribuem para a melhoria das relações interpessoais.

Este relato reside na importância da aplicação de valores humanos ecológicos no contexto escolar, orientando que os estudantes necessitam conviver com outros estudantes e, se a convivência for harmônica, com respeito à individualidade de cada um, poderemos ter mais prazer pelo ambiente escolare, um mundo melhor. Uma formação em valores autotranscendentes nos estudantes deve promover a capacidade de discernimento, fortalecer as virtudes positivas já existentes em cada um e incentivar a superação de conflitos.

\subsection{Educação Ambiental e Ecologia Humana}

Por ser uma atividade que implica mudanças profundas, a Educação Ambiental está longe de ser uma atividade de fácil desenvolvimento, conforme os PCN (1997b), ao contrário, quando bem realizada "leva a mudanças de comportamento pessoal e a atitudes e valores de cidadania que podem ter fortes conseqüências sociais" (p.23), utilizando-se do convívio escolar como fator determinante para essas aprendizagens (p.37).

A Educação Ambiental é um direito de todos os cidadãos brasileiros comprometendo a escola a exercer o mais puro exercício de cidadania (LAYRARGUES, LIPAI, PEDRO, 2007), devendo resgatar valores éticos e democráticos, preparando as pessoas para exigir justiça social, promover o senso crítico e autocrítico, ampliar a percepção e produzir mudanças (PALMER, 2006, APUD SOUZA, 2013), na perspectiva de construir relações mais harmônicas. 
Pela Educação Ambiental podemos despertar nos estudantes a vontade de construir o futuro com novas atitudes e comportamentos com responsabilidade sobre suas ações (CARVALHO, 2014), formando valores que os levem a reflexões sobre suas condutas e relações com as pessoas, com a natureza e com os diversos ambientes. Podemos, também, discuti-la como sendo um eixo norteador na mudança de comportamento quando formamos pessoas conscientes e sensíveis, sujeitos críticos e atentos aos problemas socioambientais, com vistas à transformação da sociedade (GIORDAN e GALLI, 2014) e de si mesmos.

Nesta concepção de educação - Educação Ambiental - as mudançasde condutas nos estudantes podem influenciar nas suas relações interpessoais no ambiente escolar. Este aspecto prima por uma educação para a vida, acontecendo a partir das relações humanas e não apenas no campo das idéias, envolvendo uma preocupação com a totalidade do ser (MORAES, 2008), ou seja, dos estudantes. Para que isso ocorra, procura-se uma educação vivencial onde as práticas possam ser internalizadas e transformadas em comportamentos inovadores com novos modos de viver, abrindo oportunidades de fazer emergir novos sentimentos sobre novas relações, conduzindo o estudante a novas formas de pensar (MENDONÇA, 2007).

Nessa perspectiva é importante desenvolver intervenções com formação em valores de autotranscendência para que os estudantes possamvivenciar ações cooperativas e em equipe, possibilitando a integração entre os demais colegas da sala de aula, e refletir sobre regras e normas existentes na sociedade (dimensão social); estimular a busca do conhecimento de si e do próximo (dimensão pessoal); entender que o ser humano só consegue tomar consciência do mundo e dos outros através do amor, sabendo valorizar as qualidades das pessoas respeitando-as pelas suas diferenças, e cuidar do meio ambiente natural (dimensão socioambiental) (CORDEIRO, 2000).

O método vivencial abrange todas essas dimensões e "busca desencadear processos de auto-conhecimento e transmutação bio-psiquíca, com reflexos na relaboração de valores e hábitos-comportamentos" (DANSA, PATO, CORREA, 2014, p. 6) nos grupos trabalhados. O método vivencial procura colocar os sujeitos em situações de reflexões sobre as diferenças de opiniões dos outros, 
incorporando problemas alheios, compreendendo as diversas culturas existentes, possibilitando um trabalho lúdico, dinâmico, com atividades interativas podendo abordar os temas propostos sob diversos aspectos da dimensão individual e coletiva.

O método vivencial, promovendo uma formação em valores, possibilitará com que os estudantes reflitam sobre si mesmos e sobre suas relações inter e intrapessoais, permitindo uma visão mais sistêmica em relação, tanto aos conhecimentos científicos estudados na escola, quanto aos conflitos existentes entre seus pares. Essas vivências podem ser compartilhadas por meio de ações pedagógicas através de oficinas,como instrumentos metodológicos que auxiliam os sujeitos na troca de experiências, explicitando seus conteúdos de forma simbólica, imaginativa e criativa (CORRÊA, 2003).

As oficinaspossibilitam novas formas de manifestação de condutas, de sentimentos, de percepções. $O$ envolvimento dos participantes nas oficinas ativa processos criativos promovendo o desenvolvimento potencial individual e coletivo (MEDEIROS, 1995). Para Medeiros (1995), os potenciais individuais se transformam em potenciais coletivos, pelos espaços vivenciais que cada um possui, influenciando nos trabalhos do grupo. Esses potenciais, individuais ou coletivos, são revelados pelas dinâmicas de grupo.

Para Corrêa (2003), nas oficinas "são desenvolvidas atividades que abrem espaço para a pessoa exercitar sua sensibilidade e criatividade, possibilitando um entendimento maior de como ela vê e sente o mundo" (p.120). Para a autora, as oficinas trazem à tona as experiências dos sujeitos, compartilhando-as com as vivências propostas, possibilitando "uma nova forma de compreender a realidade e nele interferir (p.121). Conforme Antunes (2009), trabalhar com dinâmicas é criar estratégias motivadoras para um ensino vivo e para uma aprendizagem cheia de significações e transferências positivas. Para o autor, utilizar dinâmicas em sala de aula é interessante, estimulante e criativo, buscando tornar a aprendizagem significativa, pois os estudantes deixam de ser apenas expectadores para serem verdadeiros protagonistas dos saberes que aprendem. Rabelo (2012) aponta que é de extrema importância a relação de confiança e abertura entre o professor e os estudantes para que as dinâmicas sejam vivenciadas 
em um clima favorável à construção de conhecimentos, à aproximação entre os estudantes, à cooperação para o alcance de objetivos e às relações interpessoais. $A$ autora menciona que as relações interpessoais e a comunicação na escola devem propiciar um ambiente que facilite a manifestação de sentimentos e opiniões, devendo, portanto, que o professor acredite no poder transformador das relações.

Para que se tenha um bom relacionamento e sucesso no processo de aprendizagem, por meio de dinâmicas lúdicas, Rabelo (2012) aponta algumas atitudes e qualidades necessárias ao professor, como: amor espontâneo e sincero, demonstrando afetividade nas ações; flexibilidade em aceitar sugestões dos estudantes e dos outros; senso de humor; curiosidade, potencializando a criatividade dos estudantes; jovialidade, independentemente de sua idade cronológica, manter o vigor sempre renovado; respeito à diversidade, onde cada estudante tem "seu jeito" ; comunicação eficaz, sendo clara e compatível com o nível dos estudantes; impessoalidade, cuidar de todos indistintamente, evitando predileções; e motivação, oferecer ao estudante a possibilidade de sucesso.

A cada dia somos desafiados a mudar e a inovar com o intuito de atender às novas exigências dos estudantes, transformando a sala de aula no melhor lugar para aprender, construindo um espaço dinâmico e participativo. As dinâmicas devem ser inovadoras a cada encontro, com responsabilidade, objetivos claros e reflexões com discussões ao término das mesmas.

Essas vivências podem promover um maior desenvolvimento dos aspectos afetivos, maior percepção dos conceitos e interações, e são complementares aos processos educativos que focam nas informações e conhecimentos (MENDONÇA, 2007). Posto isso,outro objetivo desta pesquisa é testar a hipótese de que um trabalho de intervenção pedagógica, por meio de oficinas, utilizando dinâmicas cooperativas com foco em valores humanos, pode contribuir para a transformação e melhorias nas relações interpessoais dos estudantes.

A Educação Ambiental perpassa, também, pelo corpo e alma, na construção de relações positivas entre grupos humanos na perspectiva de formar mentes saudáveis, com comportamentos positivos, buscando no cidadão o respeito 
ao outro. Corroborando com o exposto acima, Mansoldo(2012, p.26) cita que a Educação Ambiental "forma o cidadão planetário, em prol da solidariedade em escala mundial; se abre à compreensão do outro e constrói a civilização da simplicidade, da igualdade e da alegria compartilhada, objetivando uma sociedade justa" (MANSOLDO, 2012; GADOTTI, 2000).

Encontramos na Ecologia Humana essa nova forma de olhar para o que nos rodeia, podendo dar uma visão ecológica sobre os problemas humanos e suas relações com a naturezae com seus pares (SOUZA, 2007).A Ecologia Humana emerge como uma ciência que objetiva integrar as relações culturais, antropológicas, sociais e ambientais como fatores determinantes do desenvolvimento da humanidade (KORMONDY \& BROWN, 2002, APUD SOUZA, 2007). Surge, também, da necessidade de produzir conhecimento para compreender a relação do homem com o seu ambiente, para responder à interrogação de qual o seu lugar na natureza (PIRES \& CRAVEIRO, 2011).

Para Dansa, Pato e Correa (2014), a Ecologia Humana se compreende "como um campo aberto, interdisciplinar e pluriparadigmático, que nos ajuda a exercitar nossa compreensão-ação do homem no mundo numa perspectiva de construir um processo educativo que possibilite ao sujeito individual ou coletivo refazer o seu fazer, a partir da ampliação do seu próprio ponto de vista de uma forma mais complexa, criativa, integral e dialógica" (p.2). Para as autoras a educação pode contribuir para a Ecologia Humana na transmissão e fortalecimento de valores autotranscendentes como igualdade social, justiça social, respeito ao outro e ás diversas formas de vida, entre outros, nas dimensões individual, social e planetária (Pato, 2011b). Elas citam que a educação deve reorganizar o processo de conhecimento para que as pessoas possam compreender melhor seu papel no mundo, permitindo "rearticular seus valores, sua qualidade de vida e sua participação social" (p. 3).

As autoras colocam a Ecologia Humana como uma concepção de educação/gestão ambiental que permite aos indivíduos exercer seus papéis sociais de forma clara, transparente, fundamentando o trabalho educativo como "ações que visam a vivência e a reflexão coletiva e crítico-criativa, necessária à descoberta dos valores que possam fundamentar o viver humano e as relações sociedade-natureza" 
(p. 4). Neste contexto as oficinas podem contribuir para a concepção de novos valores de autotranscendência na busca pelo sujeito em formação, ou na percepção dos valores já existentes nos sujeitos.

Neste caminhar, a pesquisa analisou práticas no trabalho da temática Ambientalcom adolescentes no ambiente escolar. Esta proposta de pesquisa traz contribuições e algumas sinalizações práticas ao se trabalhar a Educação Ambiental e Ecologia Humana na intencionalidade pedagógica de se ter cidadãos mais justos, na formação de valores pessoais, e na possibilidade de mudanças de condutas visando melhorias nas relações interpessoais. Da mesma forma os PCN (1997b) propõem trabalho com a temática Ambiental visando contribuir para a formação de cidadãos conscientes, aptos a atuarem na realidade socioambiental de modo comprometido com a vida, com o bem-estar de cada um e da sociedade, local e global. Propõe, também, que a escola trabalhe com atitudes e com formação de valores para que comportamentos "ambientalmente corretos" sejam aprendidos na prática escolar diária.

\subsection{A formação do sujeito ecológico na perspectiva da Ecologia Humana}

Para Carvalho (1998) um grande desafio para a Educação Ambiental é unir sujeitos amorosos e sensíveis à natureza, a uma educação que forma sujeitos atentos aos problemas socioambientais e capazes de interferir nas decisões da sociedade. Estes sujeitos seriam engajados na construção de uma nova cultura, com novos comportamentos, novos valores, formando sujeitos éticos e políticos, apontando para um jeito ecológico de ver e viver a vida, pensando em si e nas relações com os outros neste mundo (Carvalho, 2011). Surge o sujeito ecológico.

Carvalho (2011) define sujeito ecológico como sendo um sujeito que detém os ideais de vida nos valores ecológicos, agregando traços, valores e crenças num mundo transformado com esperanças de viver melhor, de felicidade, de justiça e de bem-estar, apostando na possibilidade de mudanças nos estilos de vida, tanto individual quanto coletivamente. A autora comenta que pessoas com a identificação social e individual com valores ecológicos, ocorrendo dentro e fora da escola, é um processo formativo buscando a formação de um sujeito ecológico (2007). 
A autora também cita que o sujeito ecológico compartilha a noção de bem viver (ecológico) com vistas na regulação das relações entre sociedade e natureza, instituindo um "estilo de vida que incorpora novos hábitos e atitudes em várias esferas da vida" (CARVALHO e STEIL, 2009, p. 84). Carvalho (2004) comenta que uma aproximação dos jovens com os ideais ecológicos pode assumir nas "formas da adesão a uma luta, a uma ação, a um modo de vida e a um interesse intelectual" (p.18), abarcando não apenas uma nova sociedade, mas também, "um novo sujeito que se vê como parte de uma mudança societária compreendendo como uma revolução de corpo e alma" (p.19).

Pensando o sujeito ecológico em permanente formação na sua inteireza, abrangendo as dimensões afetivas, motivacionais e transcendentes, conectando-se à natureza, encontramos a Ecologia Humana como parte integrante e conectora desse processo. Pela Ecologia Humana esse sujeito procura estimular a cooperação através da ajuda, da solidariedade aos colegas, destacando a importância dos valores autotranscendentes, possibilitando mudanças nas relações intra e interpessoais dos sujeitos nos mais variados ambientes.

No ambiente escolar a preocupação primeira é a busca pelo bem-estar dos estudantes, respeitando a si e aos demais colegas da escola, priorizando práticas coletivas de ajudas mútuas com vivências de solidariedade e cooperação. Sendo a escola um ambiente passível para reflexões e práxis de transformações e mudanças nas relações humanas, a Ecologia Humana encontra lugar para influenciar na construção do sujeito ecológico (CATALÃO, MOURÃO, PATO, 2009).

O sujeito ecológico encontra-se, permanentemente, em construção, portanto, suscetível a novas aprendizagens e a formação de valores que promovam atitudes e comportamentos ecológicos. A formação em valores, com foco nos ecológicos (PATO, 2011b) e de autotranscendência (SCHWARTZ, 2005), pode contribuir para a mudança de atitudes e comportamentos dos estudantes, visando à construção de relações mais sustentáveis, favorecendo a resolução de conflitos e a proteção socioambiental. 


\section{Capítulo 2. VALORES HUMANOS E EDUCAÇÃO}

Valores são estruturas abstratas, associados à emoção, influenciando escolhas e comportamentos, representando metas pessoais conscientes e desejadas, podendo servir de critérios usados pelas pessoas em suas tomadas de decisões (SCHWARTZ APUD PATO, 2004).

Para Schwartz (2005), pensar em valores é pensar naquilo que é importante para cada indivíduo, de modo que as coisas que são importantes para uma pessoa, não são, necessariamente, para outras. Valores pessoais estão vinculados às emoções, positivas ou negativas. Rokeach (1981, p.132) define valores como crenças que guiam de maneira transcendente nossas ações e julgamentos; são o componente central da nossa personalidade, ordenados ao longo de um continuum de importância. Para o autor uma vez internalizado, o valor se torna "consciente ou inconscientemente, um padrão ou critério para guiar a ação, desenvolver e manter as atitudes em relação a objetos e situações relevantes, para julgar moralmente a si e aos outros e para se comparar com outros".

No entendimento de Pato (2011b) valores podem ser interpretados como um "sistema referencial, uma orientação ou atitude humana preferencial, positiva e desejada em relação a objetos, pessoas ou situações” (p. 296). Nepomuceno (2007) informa que pela perspectiva teórica da Psicologia Social, a raiz dos valores é de ordem motivacional, possibilitando a compreensão e predição do comportamento humano; que valores são o centro da personalidade dos indivíduos; que possuem uma hierarquia, apresentando uma ordem de importância na vida das pessoas; portanto, "orientam e controlam comportamentos dos indivíduos, visto que esses estão sempre em busca das metas estabelecidas relacionadas tanto à individualidade, quanto à coletividade" (p. 7).

Para Schwartz (2005) os valores favorecem o aparecimento de comportamentos adaptativos a vários ambientes, sendo importantes para compreender o pensamento e ações humanas; e influenciam o nosso comportamento, principalmente quando esse comportamento implica em conflitos de 
valores podendo sofrer influência da fase etária. Desta forma, os valores funcionam como referenciais internos que justificam nossas escolhas e condutas, sendo necessário percebê-los e desvelá-los nos estudantes e transformar essa descoberta em prática cotidiana, (MARQUES, 2012).

Para Schiffer (2008), o ato de educar em valores humanos tem como meta despertar a consciência dos valores como herança e conquista da personalidade, despertando visões renovadoras de respeito ao próximo, podendo definir o ser humano de acordo com os seus valores e sua prática. Em linhas gerais, os valores humanos são compreendidos como importantes metas ou normas que servem como princípios-guia na vida das pessoas (ROKEACH, 1968/1981; SCHULTZ \& ZELEZNY, 1999; APUD COELHO, GOUVEIA, MILFONT, 2006).

A educação é o meio mais eficaz para a transmissão de valores, permitindo que a sociedade possa enfrentar situações conflitantes do presente e do futuro. Não é, certamente, o único meio, mas pode promover reflexões e discussões sobre os problemas existentes. A educação, em seu sentido mais amplo, deve ser parte vital de todos os esforços que se façam para imaginar e criar novas relações entre as pessoas e fomentar maior respeito pelo meio ambiente (UNESCO, 1999).

Porém, a educação vem perdendo suas referências de como formar às gerações futuras, necessitando "descobrir novos caminhos pedagógicos para lidar com este momento" (DANSA, PATO, CORRÊA, 2014, p. 3). Para Dansa, Pato e Corrêa (2014) um desses caminhos poderia ser o investimento da educação na transmissão e fortalecimento de valores autotranscendentes, que envolvem as dimensões individual, social e planetária, cabendo "à educação reorganizar o processo de conhecimento, a partir de novas premissas, utilizando-se de todas as dimensões do ser humano" (p. 3).

Neste olhar, Catalão, Mourão e Pato (2009) comentam que a educação permitirá ressignificar os conceitos de cidadania, qualidade de vida, sustentabilidade, liberdade e valores humanos para a existência e convivência plena dos seres humanos. Sob a ótica da abordagem transversal e transdisciplinar, as autoras apontam possibilidades para uma metodologia que contemple práticas educativas 
que visam resgatar a articulação entre os aspectos pessoais, socioculturais e naturais que dão sustentação à vida no planeta.

Quaisquer que sejam as práticas educativas propostas e como já mencionado anteriormente, é necessário que a educação se volte para a formação integral e integrada às várias dimensões do sujeito, neste caso os estudantes. Várias propostas de ação educativa de caráter formativo foram se estruturando, abrangendo também a Educação Ambiental, enfatizando a necessidade de despertar o ser humano para o sentir, pensar e agir comprometidos com a vida, incluindo a natureza e todas as suas formas de manifestação. Para Viana e Höeffel (1998) a concepção desse ser humano resulta da integração de vários níveis: físico, intelectual, psíquico, mental e espiritual, onde a educação deve atuar formando hábitos e atitudes referenciados em valores para que possa abranger a formação do ser humano em sua inteireza.

Uma educação centrada em valores pode promover a transformação dos sujeitos e, conseqüentemente, de suas relações e inter-relações, visto os valores serem centrais tanto no sistema pessoal quanto no cultural e social e influenciam as crenças, as atitudes e os comportamentos, entre outros (PATO, 2004; SCHWARTZ, 2005).Nesta dimensão educativa e no ideário de que é possível a mudança e a melhoria da sociedade, Serrano (2002) afirma que a educação em valores é uma tarefa complexa, cheia de riscos e incertezas, necessitando de uma formação adequada. Esta pesquisa também teve como objetivo avaliar as possíveis mudanças ocorridas nos estudantes após uma formação em valores por meio de oficinas.

Na perspectiva de Dansa, Pato e Corrêa (2014) o sujeito está em constante processo de formação e autoformação, envolvendo a dimensão pessoal, que, por sua vez, envolve os aspectos cognitivos, afetivos, motivacionais, relacionais, e que em outras perspectivas esse sujeito se constrói com ênfase nos aspectos sociopolíticos (CARVALHO, 2011). 


\subsection{Teoria de Valores Humanos de Schwartz}

Em 1992, Schwartz desenvolveu uma escala de valores com o objetivo de testar as hipóteses derivadas de sua teoria, que busca explicar a estrutura dinâmica das relações entre valores. Estes valores respondem a três tipos de necessidades humanas: necessidades das pessoas como organismo biológico; de uma interação social coordenada; e da necessidade de sobrevivência e bem-estar coletivo.

Conforme Bilsky (2009), identificamos um grande número de valores sendo agrupados em categorias ou tipos de valores, destacando o conteúdo motivacional como critério para diferenciá-los. No total, Schwartz (1992, apud Bilsky 2009) distingue 10 tipos motivacionais de valores: poder, realização, hedonismo, estimulação, autodeterminação, universalismo, benevolência, tradição, conformidade e segurança. Segue quadro abaixo com uma breve caracterização desses tipos:

\begin{tabular}{|c|c|}
\hline $\begin{array}{l}\text { Tipos motivacionais } \\
\text { de valores }\end{array}$ & Conteúdo motivacional \\
\hline Poder & statussocial sobre as pessoas e recursos \\
\hline Realização & $\begin{array}{l}\text { sucesso pessoal mediante a demonstração de competência } \\
\text { segundo critérios sociais }\end{array}$ \\
\hline Hedonismo & prazer e senso de gratificação para consigo \\
\hline Estimulação & entusiasmo, novidade e desafio na vida \\
\hline Autodeterminação & $\begin{array}{l}\text { pensamento independente e escolha da ação, criatividade e } \\
\text { exploração }\end{array}$ \\
\hline Universalismo & $\begin{array}{l}\text { compreensão, apreciação, tolerância e proteção do bem- } \\
\text { estar de todas as pessoas e da natureza }\end{array}$ \\
\hline Benevolência & $\begin{array}{l}\text { preservação e intensificação do bem-estar das pessoas } \\
\text { com quem mantêm contatos pessoais freqüentes }\end{array}$ \\
\hline Tradição & $\begin{array}{l}\text { respeito aos costumes e idéias providos pela cultura } \\
\text { tradicional e pela religião, comprometimento com eles e sua } \\
\text { aceitação }\end{array}$ \\
\hline Conformidade & $\begin{array}{l}\text { restrição das ações, inclinações e impulsos que podem } \\
\text { perturbar e ferir os outros ou violar as expectativas e } \\
\text { normas sociais }\end{array}$ \\
\hline Segurança & $\begin{array}{l}\text { segurança, harmonia e estabilidade, da sociedade, dos } \\
\text { relacionamentos e de si mesmo }\end{array}$ \\
\hline
\end{tabular}

Os 10 tipos motivacionais são reorganizados em quatro grandes grupos, ou dimensões, que são: autotranscendência,abertura à mudança, conservação e 
autopromoção. Essas quatro dimensões são representadas de forma bipolar, com valores opostos entre si, no qual os tipos motivacionais de abertura à mudança se opõem aos de conservação, e os de autopromoção se opõem aos de autotranscendência (PATO, 2004). Esses tipos são representados em círculo, conforme quadro demonstrativo abaixo, formando um continuun de motivações que se relacionam com os valores adjacentes, e que também representam valores que colidem por serem contrários aos valores opostos. Como exemplo, a busca de novidades e mudança (valores de estimulação) tende a ser opostos aos valores de tradição, que busca a preservação de costumes antigos e honrados, e que estão em lados contrários na estrutura.

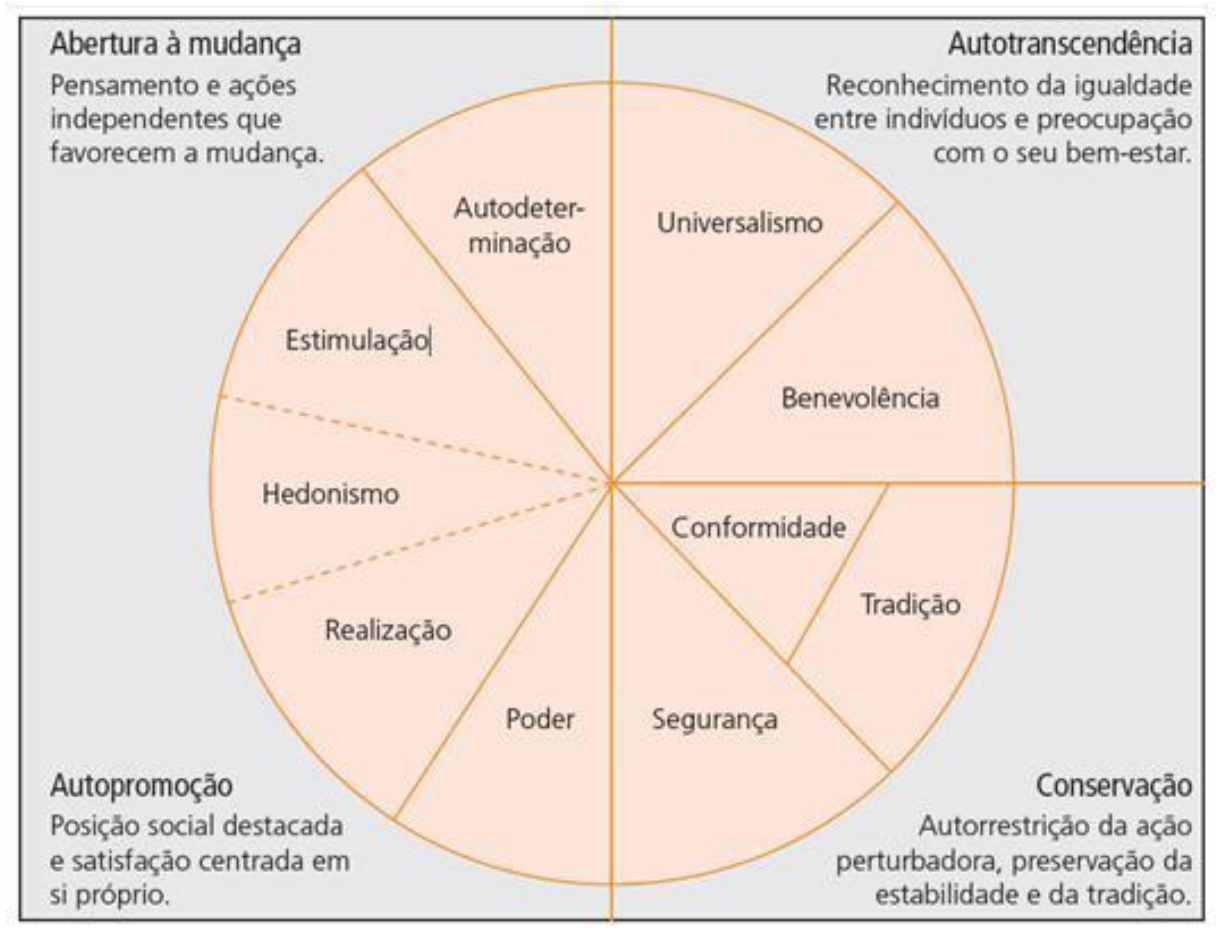

Quadro 2: Modelo dos 10 tipos de valores motivacionais de Schwartz.

Nesta estrutura circular, cada fatia representada por um tipo motivacional compartilha metas com os tipos motivacionais adjacentes. Pato (2004) esclarece que quanto mais afastados os tipos motivacionais estiverem, nessa ordem circular, mais conflitos encontraremos em suas metas. 
A seguir, os valores associados a cada um dos 10 tipos motivacionais de Schwartz (2005):

\begin{tabular}{|l|l|}
\hline \multicolumn{1}{|c|}{$\begin{array}{c}\text { Tipos } \\
\text { motivacionais }\end{array}$} & \multicolumn{1}{c|}{ Valores associados } \\
\hline Poder & $\begin{array}{l}\text { Autoridade, saúde, poder social, preservação de imagem } \\
\text { pública, reconhecimento social }\end{array}$ \\
\hline Realização & $\begin{array}{l}\text { Ambição, ser bem-sucedido, capaz, influente, inteligente, } \\
\text { auto-respeito e reconhecimento social }\end{array}$ \\
\hline Hedonismo & Prazer, vida de prazer, auto-indulgência \\
\hline Estimulação & Vida variada, vida excitante, ousadia \\
\hline Untodeterminação & $\begin{array}{l}\text { Criatividade, liberdade, autonomia de escolha, } \\
\text { curiosidade, independência, auto-respeito, inteligência e } \\
\text { privacidade }\end{array}$ \\
\hline Benevolência & $\begin{array}{l}\text { Respeito, Mente aberta, justiça social, igualdade, mundo } \\
\text { de paz, beleza, unidade com a natureza, sabedoria, } \\
\text { proteção do meio ambiente }\end{array}$ \\
\hline Tradição & $\begin{array}{l}\text { Ser prestativo, honestidade, piedade, responsabilidade, } \\
\text { lealdade, amizade, amor maduro }\end{array}$ \\
\hline Conformidade & $\begin{array}{l}\text { Respeito às tradições, humildade, devoção, ciência dos } \\
\text { limites, moderação e vida espiritual }\end{array}$ \\
\hline Segurança & $\begin{array}{l}\text { Obediência, autodisciplina, polidez, respeito aos pais e } \\
\text { mais velhos, lealdade e responsabilidade }\end{array}$ \\
\hline & $\begin{array}{l}\text { Ordem social, segurança da família, segurança nacional, } \\
\text { limpeza, reciprocidade de favores, vida saudável e senso } \\
\text { de pertencimento }\end{array}$ \\
\hline
\end{tabular}

Quadro 3: Valores associados aos 10 tipos motivacionais.

Fonte: RESENDE (2014), Dissertação de Mestrado em Educação pela UnB.

Os tipos motivacionais também indicam o nível de interesses que as pessoas podem ter na sua vida diária, organizados em individuais (autodeterminação, estimulação, realização, hedonismo e poder), coletivos (benevolência, conformidade e tradição) ou mistos (segurança e universalismo) que são interesses individuais e coletivos ao mesmo tempo.

\subsubsection{Outros olhares para valores}

Bilsky (2009) cita que os valores são crenças e metas conscientese que representam respostas que os indivíduos e sociedades devem dar às suas 
necessidades como organismos biológicos, às exigências da interação social e aos requisitos para o bem-estar e a sobrevivência da coletividade.

Tamayo (2007) explica que, como parte dos valores humanos, os valores pessoais são metas motivacionais, expressando o que uma pessoa quer atingir na sua vida, portanto, têm um papel dominante no comportamento dos seres humanos.

Para Pato e Tamayo (2002) o estudo de valores auxilia na compreensão da cultura, explicando os modos de agir de um povo, seus costumes, normas sociais, padrões de comportamentos, entre outros. Os autores explicam que a natureza dos valores permite realizar estudos sobre atitudes e comportamentos de um grupo, visando modificações comportamentais e transformações sociais, entre outros.

No caminhar para reverter situações que afligem a humanidade como, a injustiça, as guerras, a violência, o terrorismo, a impunidade e a destruição ambiental, Gaudiano e Katra (2009) apontam os valores como se constituindo "qualidades estruturais" (p. 54) para a construção de melhores modos de pensar, de atuar, de ser, gerando compreensão, estima e apreço, significando espaço para tomada de consciência e impedido reações adversas com o próximo. Os autores citam que educar em valores, eticamente, significa promover nos sujeitos a elaboração e o desenvolvimento de uma moral racional, de modo autônomo e comprometido, para que possam tomar decisões pessoais, através do "exercício de sua liberdade responsável" (p.56). O olhar dos autores reflete a importância na formação de valores humanos em promover uma qualidade de vida nas pessoas, através de ações positivas.

Para Rodrigues, Assmar e Jablonski (2000), valores são categorias gerais dotadas também de componentes cognitivos, afetivos e predisponentes de comportamento, e que alguns valores podem gerar uma infinidade de atitudes.

$\mathrm{Na}$ intenção de inculcar valores humanos na educação de sujeitos em prol de uma civilização melhor, Pozatti (2012) propõe processos educativos para uma convivência harmônica e voltada ao desenvolvimento da consciência, à inteireza do Ser. 
Puig e Garcia (2010) dizem que valores são guias de conduta que atuam quando a pessoa se encontra em situações controvertidas, evidenciando definir sua hierarquia de valores, ajudando a ter um comportamento mais orientado e coerente para tomar decisões com consciência e autonomia.

Dialogando com o tema, Corrêa (2003) diz que quando os valores e princípios de uma sociedade se encontram em crise, há a necessidade de as pessoas se reorientarem na sua formação e seus valores, para poderem aproveitar positivamente o momento de transformação, tomar consciência de tudo que vinha sendo feito e "assumir coletivamente a construção de nossa vida comum, de buscar soluções inovadoras antes que os problemas do presente se tornem irreversíveis" (p. 107) na busca de uma sociedade mais solidária.

Bons valores são práticas vivenciadas nas diferentes oportunidades, sugerindo o desenvolvimento de todas as qualidades do ser humano, cita Marques (2012). A autora explica que, espera-se que por uma educação em valores as pessoas aprendam a relacionar-se com os outros; que aprendam a respeitar e escutar o outro; a ser solidárias e tolerantes; que aprendam com os acertos e erros de modo construtivo; e trabalhar em grupo de maneira cooperativa e compartilhada. Comenta que "valores não alteram o mundo, não modificam os relacionamentos, não humanizam as relações, mas a prática desses valores, sim" (p. 20). A autora cita que quando os valores são praticados se transformam em virtudes, significando que devemos optar por uma educação que trilhe os caminhos da generosidade, honestidade, humildade, solidariedade, entre outros valores de autotranscendência.

Para Hitlin (2003, apud Borges e Marturano, 2012) "valores são metas transituacionais desejáveis, que variam em importância e servem de princípios norteadores na vida de uma pessoa" (p. 69). As autoras expressam que valores são emocionalmente carregados de idéias daquilo que se deseja.

Reflexões sobre valores na educação, faz Antunes (2009) propor que se retire da escola a imagem de um espaço competitivo, transformando-a em ambiente no qual se ensina solidariedade, em que o estudante aprende a se conhecer e a respeitar o outro. Forma-se um espaço cooperativo, cujos valores se baseiam na ajuda mútua, num olhar para o coletivo. 
Visto isso, a pesquisa com estudantes no ambiente escolar provocou reflexões a respeito dos cuidados com os colegas, fornecendo subsídios para que possam fazer suas escolhas de forma consciente.

\subsection{Valores ecológicos}

Para Pato (2011b), valores ecológicos são aqueles valores humanos que relacionamas pessoas com o ambiente, visando ao equilíbrio e à sustentabilidade, relacionando crenças, atitudes e comportamentos ecológicos, consequentemente, estes,são ações das pessoas visando "contribuir para proteger o meio ambiente ou para minimizar o impacto ambiental de outras atividades" ( 2011a, p.122).

Nessa ótica, Pato insinua que na sua perspectiva conceitual, os valores ecológicos são os que dão o sentido da vida; o senso de pertencimento promovendo relações sociais cooperativas; e os que se preocupam com o bem-estar da sociedade como um todo e com a natureza, ou seja, com os de autotranscendência de Schwartz.

No ambiente escolar a transmissão de valores dos tipos de benevolência e de universalismo que enfatizam a preocupação com o bem-estar dos outros e da natureza, pode propiciar nos estudantes a motivação necessária para a mudança de atitudes e comportamentos, como, ser prestativo, honesto, responsável, leal, igualdade, justiça social e harmonia interior, entre outros. Exemplos de estudantes que apagam as luzes ao sair da sala de aula, que não desperdiçam água no bebedouro, que jogam lixo na lixeira, lavam as mãos no tempo necessário, respeitam os demais colegas, discutem com professores sobre regras e normas de forma amistosa, preservam o patrimônio escolar, e muito mais, são provavelmente, sujeitos ecológicos em construção.

Da mesma forma, intuitivamente, Antunes (2012) busca na questão da disciplina em sala de aula o preposto que "transformar a ideia disciplina em um valor" (p.17), faz com que ela seja vista como uma qualidade humana, imprescindível à convivência e fundamental para as relações interpessoais. $\mathrm{O}$ autor 
explica que a idéia desse valor disciplina não deve chegar ao estudante como um castigo ou de forma imperativa do mais forte para o mais fraco, porém, utilizá-la na perspectiva de construir debates, reflexões e discussões de regras, princípios e normas que são essenciais a todos.

Nessa ótica, há uma convergência entre o autor e a perspectiva de formação em valores ecológicos, que é a de poder contribuir para a tomada de consciência dos sujeitos, a autonomia e a reflexão crítica, empoderando-os e incentivando-os a autoformação, o autoconhecimento e seu contínuo crescimento pessoal (PATO, 2011b). Dessa forma, Antunes (2009) complementa ser a escola um ambiente no qual se ensina solidariedade, em que o estudante aprende a se conhecer, e a conhecer e respeitar integralmente o outro.

Experiências realizadas (PATO, 2004) indicaram que se as pessoas transcenderem interesses individuais, imediatistas e egoísticos e se preocuparem mais com o bem-estar de todas as pessoas buscando interesses voltados à coletividade, indo além de seu círculo familiar e de amizades mais próximas, elas podem apresentar uma visão mais ecológica entre o ser humano e a natureza. Provavelmente essas são pessoas que buscam valores de autotranscendência, sendo capazes de agir em favor da proteção ambiental e cultural, promovendo mudanças e transformações em si e na sociedade, com a perspectiva de constituir valores ecológicos 


\section{Capítulo 3. O MÉTODO}

Este capítulo descreve o método utilizado, apresentando, os sujeitos da pesquisa; as estratégias metodológicas; os instrumentos utilizados; os procedimentos metodológicos aplicados no estudo e as análises de dados utilizadas.

Considerando-se os objetivos pretendidos, que envolvem dimensões quantitativas e qualitativas, foi utilizado o método misto (ou multimétodo), na perspectiva de (CRESWELL, 2010). O estudo aqui apresentado foi realizado em três etapas, sendo duas quantitativas e uma qualitativa, configurando a abordagem multimetodológica sequencial.

A primeira etapa consistiu na dimensão quantitativa de levantamento dos valores pessoais de todos os estudantes da escola, permitindo a seleção das turmas participantes da etapa seguinte, de formação de valores por meio das oficinas pedagógicas, que consistiuda dimensão qualitativa da pesquisa. Por fim, na terceira etapa foi feito um novo levantamento dos valores pessoais, dessa vez apenas dessa amostra da dimensão qualitativa, utilizando-se o mesmo instrumento da coleta inicial na primeira etapa.

\subsection{Os Participantes}

A pesquisa foi realizada no Centro de Ensino Miguel Arcanjo, localizada na cidade de São Sebastião / D.F, uma escola da rede pública de ensino fundamental II do Distrito Federal. A seguir, serão apresentadas as características dessa população, que participou da primeira etapa da pesquisa e a amostra dos participantes envolvidos nas segunda e terceira etapas da pesquisa - os sujeitos participantes das intervenções pedagógicas. 


\subsubsection{Caracterização dos participantes do survey}

O Centro de Ensino Miguel Arcanjofica na avenida São Bartolomeu, ao lado da Vila Olímpica, funcionando nos turno matutino e vespertino, com 1.140 estudantes matriculados.

Foram aplicados 1.000 questionários, sendo excluídos 20 por constar alguma irregularidade para a análise dos dados, como marcações em mais de um item para a mesma frase ou várias frases sem marcações ou marcações de um mesmo item em várias frases.

Segue tabela com as características da população:

\begin{tabular}{c|c|c|c|c|c}
\hline & $6^{\circ}$.ano & $7^{\circ}$.ano & $8^{\circ}$.ano & $9^{\circ}$.ano & Total \\
\hline \hline Alunos no matutino & 126 & 97 & 122 & 162 & $\mathbf{5 0 7}$ \\
Alunos no vespertino & 239 & 141 & 93 & -- & $\mathbf{4 7 3}$ \\
\hline $\begin{array}{c}\text { Médias das faixas } \\
\text { etárias (em anos) } \\
\text { Matutino } \\
\text { Vespertino }\end{array}$ & 11,5 & 12,5 & 13,7 & 14,4 & $\mathbf{1 3 , 0 4}$ \\
\hline $\begin{array}{c}\text { Faixa etária em } \\
\text { porcentagens ( \% ) }\end{array}$ & $37 \%$ & $12,9 \%$ & 13,6 & -- & $\mathbf{1 2 , 9 1}$ \\
\hline \hline Sexo Feminino & 171 & 126 & 118 & 87 & $\mathbf{5 1 , 2 \%}$ \\
$\quad$ Masculino & 194 & 111 & 98 & 75 & $\mathbf{4 8 , 8} \%$ \\
\hline \hline
\end{tabular}

Tabela 1: Características da população estudada.

A seguir, serão apresentadas as características dos sujeitos participantes das intervenções pedagógicas, a amostra da pesquisa. 


\subsubsection{Caracterização dos participantes da intervenção pedagógica}

Para as análises e interpretações dos dados coletados nesta pesquisa, foram selecionadas as 02 turmas com os menores índices na dimensão autotranscendência, da Teoria de Valores de Schwartz, que representa valores voltados aos interesses coletivos, promovendo o bem-estar dos demais indivíduos e da natureza - benevolência e universalismo -, sendo observados os itens relacionados às questões de valores sociais que visam a igualdade entre as pessoas, o respeito ao próximo, e a promoção do bem-estar dos outros e da natureza. Foram selecionadas as turmas do 8므 no matutino com 36 estudantes e o 6ㄴ L no vespertino com 34 estudantes, perfazendo um total de 70 sujeitos da amostra.

As características dos estudantes da amostra estão na tabela abaixo:

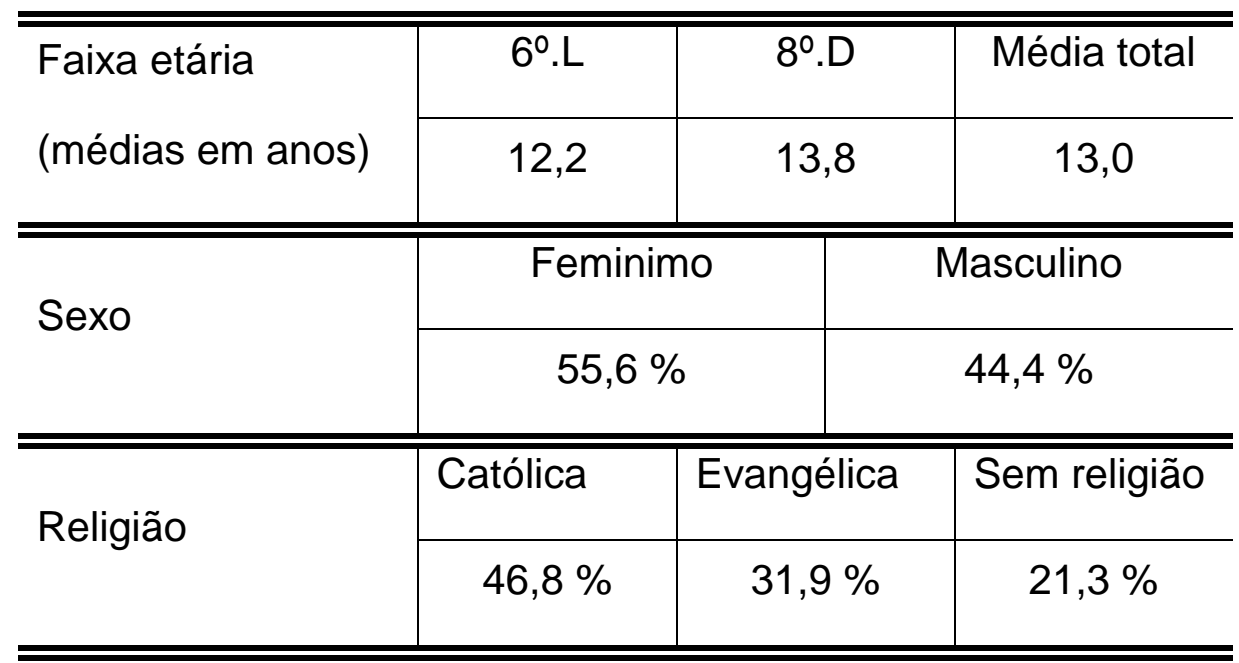

Tabela 2: Características dos participantes da pesquisa.

Sobre religião verificou-se a freqüência dos sujeitos aos cultos religiosos, com $29 \%$ informando que "dificilmente" freqüentam os cultos, $20 \%$ "sempre" freqüentam e $51 \%$ "quase sempre" freqüentam, conforme representação abaixo: 


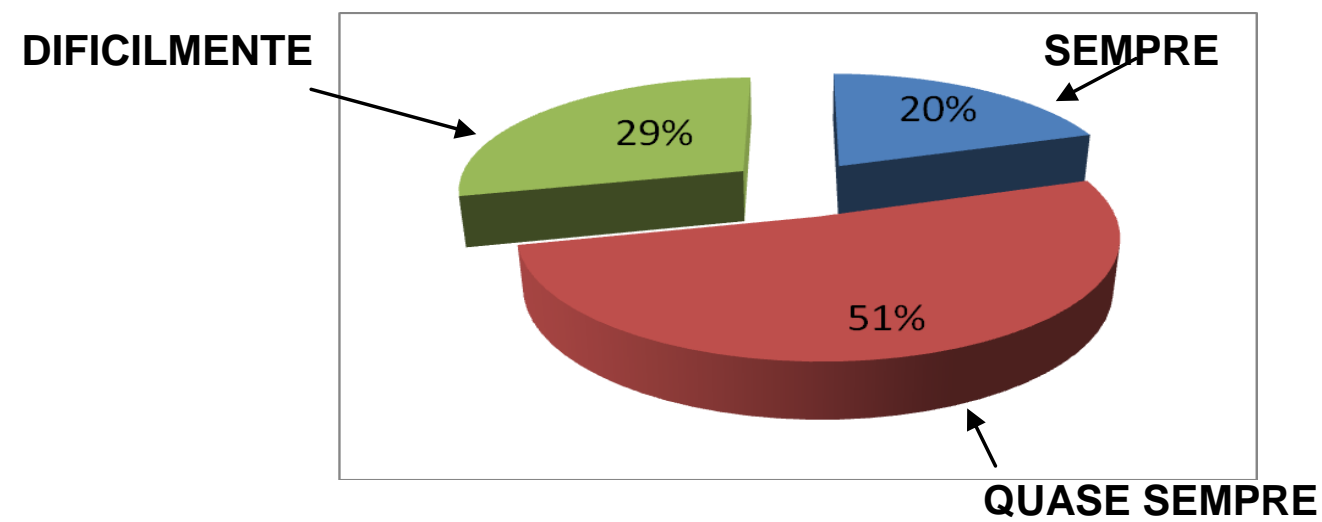

Gráfico 1: Freqüência dos sujeitos aos cultos religiosos.

Para se conhecer quem são as pessoas que moram com os sujeitos pesquisados, foi disponibilizado as seguintes opções: "Moro com: meus pais ; só mãe ; só pai ; mãe e padrasto ; pai e madrasta ; meus avós ; outros.Com estas opções encontramos as informações que $49 \%$ moram com os pais; $21 \%$ moram só com a mãe; $20 \%$ com mãe e padrasto; $4 \%$ só com o pai e $6 \%$ informaram morar com outras pessoas não constantes do formulário.

Os sujeitos também responderam sobre as suas amizades, contendo as seguintes opções:"Meu (ou minha) melhor amigo(a) é: do colégio; da rua; de casa; da família, mas não de casa; de outra cidade. Os resultados foram que 33\% dos sujeitos têm amigo(a)s no colégio; $23 \%$ são da rua; $15 \%$ são amigo(a)s de casa; $14 \%$ são da família mas não moram na casa e $11 \%$ são de outra cidade.

\subsection{As estratégias da pesquisa}

Nesta pesquisa foram utilizados um survey na primeira e terceira etapas; oficinas pedagógicas; e a observação participante com o uso de diário de campo, conforme veremos a seguir.

O survey foi realizado para investigar os valores pessoais dos estudantes da escola, por meio de um questionário, de modo a permitir um diagnóstico preliminar dos valores desses estudantes, selecionar as turmas que 
participariam da formação em valores, na segunda etapa da pesquisa e verificar se houve modificação nesses valores após o processo de intervenção.

As oficinas pedagógicas ocorreram com dinâmicas cooperativas, lúdicas e participativas, utilizando rodas de conversa ao término de cada encontro, promovendo reflexões sobre as atividades propostas. Para Pizzimenti (2013) esta estratégia é um momento de troca, de rir, de chorar, de compartilhar e que os frutos dos diálogos estabelecidos podem ser colhidos a curto e longo prazos.

$\mathrm{Na}$ observação participante o pesquisador atuou como parte integrante da pesquisa, que conforme Vianna (2003) ao observador não basta simplesmente olhar, mas saber ver e identificar os diversos tipos de interações que ocorrem nos processos humanos. Procurou-se registrar em diário de campo, as ações, reações, emoções e sentimentos dos sujeitos participantes, bem como as impressões e expressões demonstradas por eles. Foram registrados os comentários ocorridos antes, durante e depois de cada encontro com os participantes.

\subsection{Os instrumentos utilizados}

\section{a) A escala de valores pessoais - PQ21 de Schwartz (2005)}

Para o estudo de valores, foi utilizado o Perfil de Valores Pessoais de Schwartz, O PQ21 - Portrait Questionaire - que é um modelo reduzido do instrumento de valores (Apêndice A). O PQ21 apresenta 21 itens que descrevem pessoas com desejos e aspirações diversas, que representam os dez tipos motivacionais de valores individuais do modelo teórico de Schwartz. É composto por uma escala tipo Likert de 06 pontos, onde ' 1 ' refere-se a "Se parece muito comigo", e '6' a "Não se parece nada comigo".

Em seguida foram incluídas duas questões abertas para complementar com a percepção dos estudantes acerca dos valores que são transmitidos na escola e os que eles consideram importantes para a sua vida. : (1) Para você, quais são os valores que os professores transmitem durante as aulas?;e (2) E quais os valores que você considera importante para viver bem hoje em dia?. 
Ao final, foram inseridas variáveis sociodemográficas como a idade, sexo, turma e período de estudo para caracterizar os participantes da pesquisa e permitir a identificação das turmas que fariam parte da segunda etapa da pesquisa.

\section{b) Roteiro de observação}

O roteiro de observação foi utilizado na segunda etapa da pesquisa e buscou enfocar as questões relacionadas às relações interpessoais dos sujeitos, especialmente nos comportamentos manifestos no ambiente escolar.

Esse roteiro foi organizado em quatro aspectos norteadores que objetivavam: participantes;

* Observar como ocorriam as relações interpessoais dos sujeitos

* Identificar as ações e reações dos estudantes em relação a seus pares;

\section{c) Questionário com outras variáveis sóciodemográficas}

Após a décima oficina, na metade das intervenções pedagógicas, foi entregue aos sujeitos da amostra um questionário para levantar as variáveis sociodemográficas, como religião; com quem eles moravam; e as suas amizades, para melhor conhecê-los e entender possíveis influências em suas relações junto ao grupo. Este formulário de informações encontra-se no apêndice B.

\subsection{Os procedimentos}

Após o primeiro contato feito com a direção do Centro de Ensino Fundamental Miguel Arcanjo a proposta foi apresentada aos professores com total aprovação e acolhimento. $O 1^{\circ}$ questionário foi aplicado a 1.000 estudantes em todas as turmas da escola pelo próprio pesquisador, durante o mês de abril. A partir dos resultados, foram selecionadas 02 turmas com os menores escores nas médias dos tipos motivacionais de universalismo e benevolência para participarem das 
intervenções pedagógicas, as IPO, sendo uma turma de cada turno da escola (matutino e vespertino) por opção da Direção e pesquisador.

As IPO foram desenvolvidas durante os períodos das regências de classe do corpo docente, todas em salas de aula, sendo em alguns momentos, utilizadas ferramentas de apoio audiovisual como datashow e filmadora. Para tanto, pais e responsáveis autorizaram a filmagem e fotografia dos estudantes para serem apresentados, especificamente, neste trabalho de pesquisa. Foram realizados 20 encontros em cada uma das turmas, portanto, 40 encontros/atividades foram promovidos ao longo da pesquisa, destes, 60\% perduraram com o tempo de 45 minutos (uma hora aula) cada, e os $40 \%$ restantes foram trabalhados com a duração de 90 minutos (duas horas aula) em cada encontro, pois se constituíam em dinâmicas mais extensas. O quantitativo de encontros semanais foi variável, ora foram dois encontros em cada turma, ora foram três. Nas dinâmicas cooperativas foram trabalhados valores poucovivenciados no cotidiano da sala de aula como a cooperação, solidariedade, harmonia, justiça social, amizade e o valor do respeito que permeou por todas as atividades. A abordagem dos temas e seus respectivos valores foram trabalhados conforme as necessidades percebidas. Noinício de cada IPO os estudantes ficavam cientes do(s) objetivo(s) proposto(s) e dos valores a serem transmitidos, ao término ocorria uma roda de conversa onde reflexões foram construídas, citando as dificuldades encontradas, as vitórias alcançadas, os erros, os acertos e os desafios da turma.

Ao término das oficinas foi aplicado apenas nas turmas participantes um $2^{\circ}$ questionário contendo os mesmos itens do primeiro (PQ21) para comparar com os resultados das médias do questionário anterior.

\subsection{As análises dos dados}

Os dados quantitativos foram analisados com 0 uso do SPSS StatisticalPackage for Social Sciences - software de análise estatística, versão 20.0. A etapa preliminar de análise consistiu na investigação dos índices de acordo com os pressupostos para as análises multivariadas. Para analisar os dados dos 
valores pessoais dos estudantes foi utilizada a técnica estatística do MDS Escalonamento Multidimensional (Smallest Space Analysis - SSA).

Tamayo e Porto (2009) explicam que o MDS "é uma técnica que permite representar, as proximidades entre um conjunto de objetos ou estímulos como distâncias em um espaço de baixa dimensionalidade (geralmente duas ou três dimensões)" (p. 373). A representação é gráfica e a distância entre os pontos indica o grau de semelhança entre as variáveis. Assim, quanto mais próximos os pontos aparecerem no gráfico, maior a semelhança entre as variáveis. A técnica busca 0 número mínimo de dimensões para representar as correlações entre as variáveis envolvidas. Essa é a técnica utilizada nas análises de valores com base na teoria de Schwartz (2005), em razão da congruência com os pressupostos teóricos.Para os dados sociodemográficos foram realizadas análises descritivas, a fim de caracterizar os participantes.

Para as análises de dados resultantes das IPO utilizou-se a análise de conteúdo (BARDIN, 2011). Essa técnica permitiu gerar categorias de informações, verificar a percepção dos sujeitos sobre as questões nos valores pessoais, centradas nas atitudes e nos comportamentos apresentados. A escolha por esta técnica baseia-se, entre outras, na serventia de revelar atitudes, interesses, crenças e valores dos grupos estudados (GIL, 2009).

Os dados foram analisados com base num modelo misto - modelo híbrido -, permitindo que categorias prévias baseadas no modelo teórico de Schwartz, conforme os resultados apresentados no $1^{\circ}$. questionário, se interligassem às novas categorias emergentes dos dados relatados pelas observações. 


\section{Capítulo 4. OS RESULTADOS}

Este capítulo apresenta os resultados conforme a trajetória cronológica das atividades desenvolvidas. Inicia-se, portanto, pelos valores pessoais de todos os estudantes da escola investigada, em seguida, são apresentados os resultados das intervenções pedagógicas/oficinas - IPO. Por fim, são apresentados os valores pessoais dos participantes das oficinas e a integração desses resultados para a compreensão dos valores dos estudantes e do processo de formação em valores.

\subsection{Valores e médias dos estudantes de toda a escola}

A etapa preliminar de análise consistiu na investigação dos índices de acordo com os pressupostos para as análises multivariadas. Os valores ausentes foram inferiores a $5 \%$ e foram substituídos pela média em cada variável.

Os $1^{\text {os }}$. questionários revelaram os sujeitos participantes das IPO e os itens analisados foram os de universalismo e benevolência da dimensão autotranscendência. Esta dimensão aponta para valores como a promoção para 0 bem-estar com os colegas da turma, da família, compreensão, tolerância, cooperação e cuidados com a natureza, indicando nas pessoas os interesses coletivos e mistos (individuais e coletivos).

Segue tabela com os resultados encontrados neste questionário, pelo cálculo das médias em autotranscendência, em ordem crescente de valor numérico, de todas as turmas nos dois turnos da escola:

\begin{tabular}{c|c|l}
\hline \multicolumn{3}{c}{ 1․ Cenário - antes das IPO } \\
\hline & MÉDIAS & Turno \\
\hline $6 \mathrm{~L}$ & 4,28 & Vespertino \\
\hline $7 \mathrm{G}$ & 4,38 & Vespertino \\
\hline $7 \mathrm{D}$ & 4,48 & Vespertino \\
\hline $8 \mathrm{D}$ & 4,49 & Matutino \\
\hline $8 \mathrm{~A}$ & 4,50 & Matutino \\
\hline $8 \mathrm{G}$ & 4,58 & Vespertino \\
\hline $7 \mathrm{~F}$ & 4,65 & Vespertino \\
\hline $6 \mathrm{C}$ & 4,71 & Matutino \\
\hline $6 \mathrm{~A}$ & 4,72 & Matutino \\
\hline $6 \mathrm{I}$ & 4,73 & Vespertino \\
\hline
\end{tabular}




\begin{tabular}{c|l|l}
\hline $9 \mathrm{E}$ & 4,76 & Matutino \\
\hline $7 \mathrm{C}$ & 4,77 & Matutino \\
\hline $8 \mathrm{E}$ & 4,77 & Vespertino \\
\hline $9 \mathrm{C}$ & 4,77 & Matutino \\
\hline $6 \mathrm{E}$ & 4,78 & Vespertino \\
\hline $6 \mathrm{H}$ & 4,79 & Vespertino \\
\hline $9 \mathrm{~B}$ & 4,79 & Matutino \\
\hline $8 \mathrm{~F}$ & 4,82 & Vespertino \\
\hline $7 \mathrm{H}$ & 4,84 & Vespertino \\
\hline $8 \mathrm{~B}$ & 4,84 & Matutino \\
\hline $7 \mathrm{~A}$ & 4,85 & Matutino \\
\hline $6 \mathrm{D}$ & 4,87 & Matutino \\
\hline $6 \mathrm{~K}$ & 4,88 & Vespertino \\
\hline $7 \mathrm{~B}$ & 4,90 & Matutino \\
\hline $6 \mathrm{~B}$ & 4,93 & Matutino \\
\hline $6 \mathrm{G}$ & 4,95 & Vespertino \\
\hline $9 \mathrm{~A}$ & 4,95 & Matutino \\
\hline $9 \mathrm{D}$ & 4,96 & Matutino \\
\hline $7 \mathrm{E}$ & 4,99 & Vespertino \\
\hline $6 \mathrm{~J}$ & 5,05 & Vespertino \\
\hline $6 \mathrm{~F}$ & 5,06 & Vespertino \\
\hline $8 \mathrm{C}$ & 5,07 & Matutino \\
\hline
\end{tabular}

Tabela 3: Médias da dimensão autotranscendência do $1^{\circ}$ questionário.

Com estes resultados as intervenções pedagógicas foram realizadas nas turmas $8^{\circ} \mathrm{D}$ e $6^{\circ} \mathrm{L}$, respectivamente, matutino e vespertino.

No instrumento de valores pessoais - PQ21 - os estudantes responderam 'o quanto se pareciam com uma pessoa' que relaciona os itens com valores individuais. A tabela abaixo apresenta os resultados das médias e a moda em cada item do instrumento:

\begin{tabular}{l|c|c}
\hline & Médias & Moda \\
\hline $\begin{array}{l}\text { 1) Pensar em novas idéias e ser criativa é importante para ela. } \\
\text { Ela gosta de fazer coisas de maneira própria e original. }\end{array}$ & 4,4085 & 5 \\
\hline $\begin{array}{l}\text { 2) Ser rica é importante para ela. Ela quer ter muito dinheiro e } \\
\text { possuir coisas caras. }\end{array}$ & 2,7321 & 2 \\
\hline $\begin{array}{l}\text { 3) Ela acredita que é importante que todas as pessoas do mundo } \\
\text { sejam tratadas com igualdade. Ela acredita que todos deveriam } \\
\text { ter oportunidades iguais na vida. }\end{array}$ & 5,0519 & 6 \\
\hline $\begin{array}{l}\text { 4) É muito importante para ela demonstrar suas habilidades. Ela } \\
\text { quer que as pessoas admirem o que ela faz. }\end{array}$ & 4,0491 & 5 \\
\hline
\end{tabular}




\begin{tabular}{|c|c|c|}
\hline $\begin{array}{l}\text { 5) É importante para ela viver em um ambiente seguro. Ela evita } \\
\text { qualquer coisa que possa colocar sua segurança em perigo. }\end{array}$ & 4,3166 & 6 \\
\hline $\begin{array}{l}\text { 6) Ela gosta de novidade e mudança, sempre tenta fazer coisas } \\
\text { novas. É importante para ela fazer várias coisas diferentes na } \\
\text { vida. }\end{array}$ & 4,5898 & 6 \\
\hline $\begin{array}{l}\text { 7) Ela acredita que as pessoas deveriam respeitar as normas. Ela } \\
\text { acredita que as pessoas deveriam sempre seguir as regras, } \\
\text { mesmo quando ninguém está observando. }\end{array}$ & 3,7505 & 4 \\
\hline $\begin{array}{l}\text { 8) É importante para ela ouvir as pessoas que são diferentes } \\
\text { dela. Mesmo quando não concorda com elas, ainda quer } \\
\text { entendê-las. }\end{array}$ & 4,2128 & 5 \\
\hline $\begin{array}{l}\text { 9) É importante para ela ser humilde e modesta. Ela tenta não } \\
\text { chamar atenção para si. }\end{array}$ & 4,1834 & 6 \\
\hline $\begin{array}{l}\text { 10) Para ela é importante aproveitar a vida. Ela gosta de divertir- } \\
\text { se. }\end{array}$ & 5,3893 & 6 \\
\hline $\begin{array}{l}\text { 11) É importante para ela tomar suas próprias decisões sobre o } \\
\text { que faz. Ela gosta de ser livre para planejar e escolher suas } \\
\text { atividades. }\end{array}$ & 4,6347 & 6 \\
\hline $\begin{array}{l}\text { 12) É muito importante para ela ajudar as pessoas ao seu redor. } \\
\text { Ela quer cuidar do bem-estar delas. }\end{array}$ & 4,6089 & 5 \\
\hline $\begin{array}{l}\text { 13) Ser muito bem-sucedida é importante para ela. Ela gosta de } \\
\text { ser admirada pelas pessoas. }\end{array}$ & 3,9293 & 6 \\
\hline $\begin{array}{l}\text { 14) Para ela é importante a segurança. Ela gosta de sentir-se } \\
\text { segura na vida. }\end{array}$ & 4,7834 & 6 \\
\hline $\begin{array}{l}\text { 15) Ela gosta de se arriscar. Ela está sempre procurando } \\
\text { aventuras. }\end{array}$ & 4,2048 & 6 \\
\hline $\begin{array}{l}\text { 16) É importante para ela se comportar sempre corretamente. Ela } \\
\text { quer evitar fazer qualquer coisa que as pessoas possam achar } \\
\text { errado. }\end{array}$ & 3,7653 & 4 \\
\hline $\begin{array}{l}\text { 17) É importante para ela estar no comando e dizer aos demais o } \\
\text { que fazer. Ela quer que as pessoas façam o que manda. }\end{array}$ & 2,3867 & 1 \\
\hline $\begin{array}{l}\text { 18) É importante para ela ser fiel a seus amigos. Ela se } \\
\text { compromete com eles. }\end{array}$ & 5,1802 & 6 \\
\hline $\begin{array}{l}\text { 19) Ela acredita firmemente que as pessoas deveriam preservar } \\
\text { a natureza. Cuidar do meio ambiente é importante para ela. }\end{array}$ & 4,8537 & 6 \\
\hline $\begin{array}{l}\text { 20) Fazer as coisas da maneira como sempre foram feitas é } \\
\text { importante para ela. Ela busca a tradição em sua vida. }\end{array}$ & 3,3605 & 4 \\
\hline $\begin{array}{l}\text { 21) Ela gosta de divertir-se pelo prazer que Ihe proporciona. Ela } \\
\text { fica feliz em aproveitar a vida. }\end{array}$ & 5,2806 & 6 \\
\hline
\end{tabular}

Tabela 4: Médias e Moda de todos os estudantes da escola - 1ºquestionário

Para as análises seguintes foram consideradas as médias no qual os maiores valores numéricos significam que os sujeitos se identificam com as 
descrições do item, e vice-versa, com suas respectivas modas indicando as respostas mais freqüentes.

O primeiro grupo a analisar possui o maior número de itens com médias altas, se referindo aos valores da dimensão autotranscendência, indicando que os estudantes estão preocupados com as pessoas do grupo social a que pertencem; que possam ter as mesmas oportunidades na vida; que procuram ser prestativos; que o respeito é um valor a ser considerado e que acreditam que o meio ambiente, incluindo a natureza, deva ser preservado. Conforme Schwartz (2005) esta dimensão possui importantes valores para a compreensão dos comportamentos em relação ao meio ambiente.

A destacar outros valores cito os que se remetem a uma vida de prazeres, o "aproveitar a vida" faz parte das aspirações dos sujeitos, pois nesta faixa etária estão propensos às descobertas; demonstram ser curiosos e independentes, ligados ao tipo autodeterminação, significando que os estudantes se identificam com essas motivações; procuram a estabilidade nos relacionamentos dentro do grupo como necessidade básica de sobrevivência e o afastamento de ameaça à integridade física dos indivíduos (BILSKY, 2009); uma vida com desafios e novidades, porém, aceitando-a com humildade. Os resultados apontam para estudantes ousados em detrimento do conformismo da vida.

Os dados também sugerem que os estudantes não procuram ser disciplinados e que pouco se identificam com o ato de seguir regras e normas. Outro dado interessante são os valores relacionados ao tipo poder apresentando médias baixas, indicando que os estudantes não consideram importantes ser ricos e comandar outras pessoas.

Entre os dados analisados ficaram dispersas as identificações com 0 desejo de serem bem sucedidos na vida e a demonstração de suas capacidades diárias

Estes resultados apontam que os estudantes expressam interesses e desejos mais freqüentes para os interesses mistos, seguidos dos individuais e, por último, dos interesses coletivos. 


\subsubsection{O panorama dos estudantes da escola no mapa do EMD}

Do $1^{\circ}$ questionário foram calculadas as médias de cada dimensão dos valores dos sujeitos de toda escola, conforme tabela abaixo:

\begin{tabular}{lc}
\hline \multicolumn{1}{c}{ Dimensões } & Médias \\
\hline Autotranscendência & 4,7776 \\
\hline Abertura à mudança & 4,7316 \\
Conservação & 4,0122 \\
Autopromoção & 3,2591 \\
\hline
\end{tabular}

Tabela 5 - Médias das dimensões dos tipos motivacionais- todos os alunos da escola.

Estes resultados apontam que os estudantes da escola procuram preservar e fortalecer o bem-estar das pessoas, bem como aceitá-las como iguais, do que a busca pelo próprio sucesso e domínio sobre os outros. Também indica que o grupo procura curtir a vida, como prazer pessoal, como dito anteriormente.

Os resultados deste questionário permitiram compreender a configuração extraída do Mapa do EMD (I), na figura 1, representativo das relações dos tipos motivacionais dos sujeitos de toda escola, com uma grande concentração de pontos da dimensão "autotranscendência" indicando uma forte relação entre seus valores, sendo mais importante que a "autopromoção", de menor importância.

Cabe salientar que no mapa espacial bidimensional de relações entre valores, gerado pelo EMD como o mostrado na figura a seguir, não contém linhas de separação - linhas de fronteiras (SCHWARTZ, 2005), nem possui o colorido exposto. O delineamento guiou, de maneira didática, as divisões das regiões de cada tipo motivacional para facilitar as interpretações das informações. 


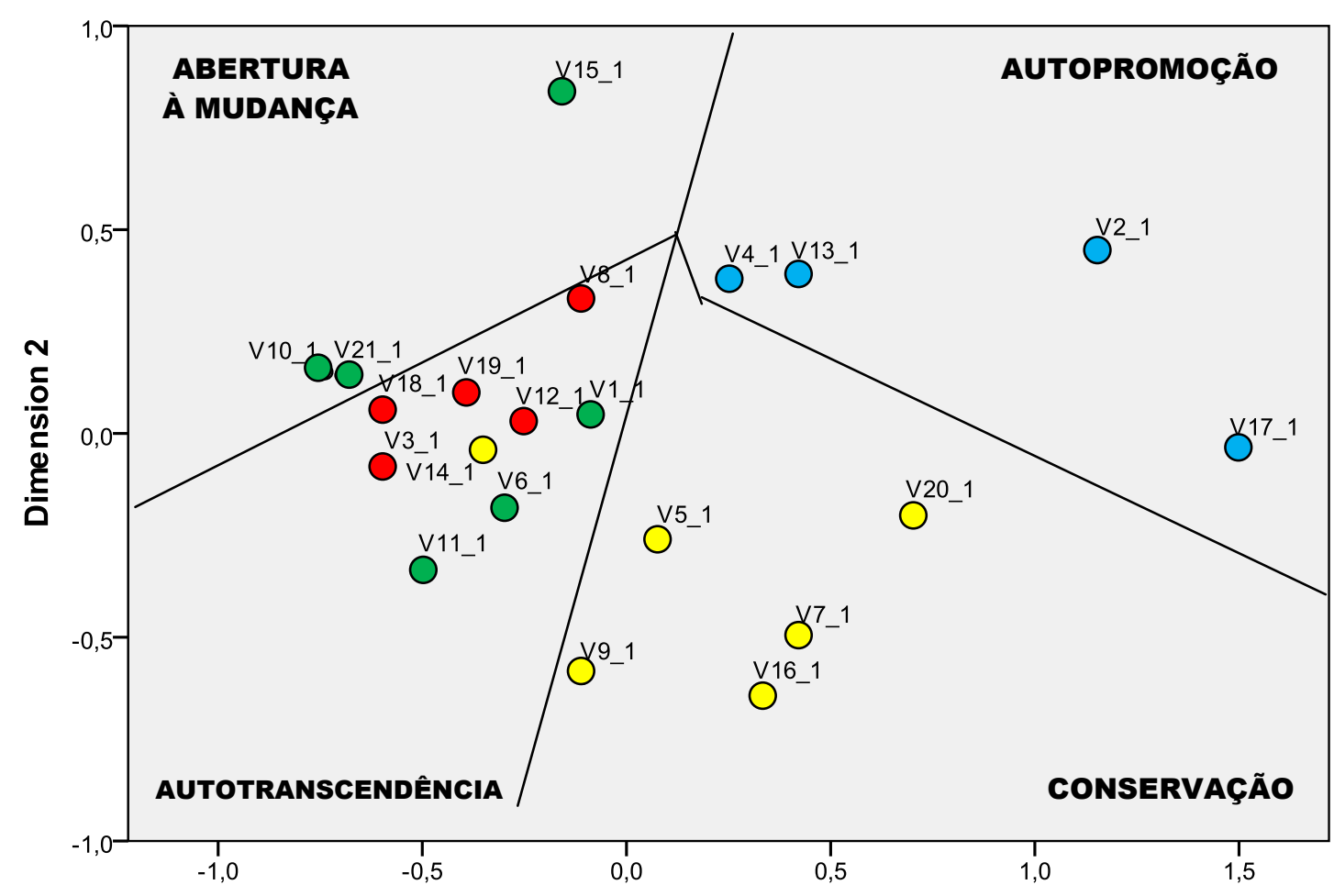

Figura 1: Mapa do EMD (I) dos tipos motivacionais de todos os estudantes da escola.

As posições geográficas dos pontos no mapa espacial bidimensional indicam as relações entre os valores e as distâncias refletem suas inter-relações. Representando as proximidades entre os valores humanos da Teoria de Schwartz e indicando o grau de semelhanças entre essas variáveis como distâncias entre os pontos em um espaço, a configuração dos tipos motivacionais de valores dos sujeitos estudados foi feita pela análise da estrutura de similaridade (Smallest Space Analysis - SSA) que é uma forma não métrica de análises de escalonamento multidimensional (EMD).

Nesta representação estrutural encontramos a organização dos tipos motivacionais em dimensões bipolares (lados opostos) definidos: "autotranscendência" (universalismo e benevolência) versus "autopromoção" (poder, realização e hedonismo) em uma dimensão, e "conservação" (conformidade, tradição e segurança) versus "abertura à mudança" (hedonismo, estimulação e 
autodeterminação) em outra. No mapa do EMD o tipo motivacional hedonismo apareceu na dimensão "abertura à mudança”.

$\mathrm{Na}$ análise da estrutura encontrada no mapa temos semelhanças no modelo teórico representativo de Schwartz, porém não idêntico. Os tipos motivacionais adjacentes foram compartilhados, como exemplo, os pontos da dimensão de "autotranscendência" próximos aos da dimensão "abertura à mudanças" indicando motivações semelhantes. Os tipos motivacionais que aparecem distantes uns dos outros expressam conflitos, como exemplo, os mesmos valores de "autotranscendência" com os da dimensão "autopromoção" com motivações opostas, obtendo a menor média e seus pontos representativos de valores dispersos.

\subsubsection{Questões abertas: os valores mais importantes para os estudantes de toda a escola}

Nas questões abertas os valores que os estudantes percebem sendo transmitidos por seus professores em sala de aula são, praticamente, os mesmos valores que eles consideram importantes para viver bem hoje em dia.

A tabela abaixo apresenta, em ordem decrescente, as freqüências dos valores transmitidos pelos professores durante suas aulas:

\begin{tabular}{|lc}
\multicolumn{2}{c}{$\begin{array}{c}\text { Valores transmitidos } \\
\text { pelos professores } \\
\text { durante as aulas }\end{array}$} \\
\hline $\begin{array}{l}\text { Respeito } \\
\text { Educação }\end{array}$ \\
Amor & $19,12 \%$ \\
Carinho & $18,03 \%$ \\
Humildade & $10,92 \%$ \\
Paciência & $9,28 \%$ \\
Honestidade & $7,10 \%$ \\
Amizade & $6,55 \%$ \\
Aprendizagem & $4,37 \%$ \\
\hline
\end{tabular}

Tabela 6: Valores transmitidos pelos professores durante suas aulas, conforme o $8^{\circ}$.D e $6^{\circ}$.L. 
Alguns valores foram classificados como dos tipos motivacionais de universalismo e benevolência, encontrando 66 do universalismo e 87 de benevolência, totalizando 153 , ou seja, $83,60 \%$ das citações feitas pelos estudantes, significando uma pré-disposição em aceitar os professores como personagens que podem ajudá-los.

A tabela a seguir apresenta, em ordem decrescente, as freqüências dos valores que os alunos consideram importantes para se viver bem hoje:

\begin{tabular}{lc}
\hline \begin{tabular}{l} 
Valores importantes para \\
\multicolumn{1}{c}{ se viver bem hoje }
\end{tabular} & $\%$ \\
\hline Respeito & $19,78 \%$ \\
Educação & $12,29 \%$ \\
Amor & 9,62 \\
Humildade & 7,48 \\
Amizade & 5,88 \\
Carinho & 5,34 \\
Paciência & 3,20 \\
Paz & 2,67 \\
Honestidade & 2,13 \\
Tabela 7: Valores que os alunos do 80 $\mathrm{D}$ 6는 \\
consideram importantes para se viver bem hoje.
\end{tabular}

Dos valores citados encontramos 60 do universalismo e 87 de benevolência, totalizando 147 , ou seja, $78,60 \%$ das citações feitas pelos estudantes, apontando aspirações, desejos e o reconhecimento que estes são os valores verdadeiros para se viver bem nesses tempos de violência.

Em ambos os caso, os valores encontrados e classificados como correspondentes do universalismo foram: igualdade, paz, sabedoria. Os de benevolência foram: honestidade, responsabilidade, amizade, amor.

Um tema futuro a ser estudado é sobre o fato de o valor da honestidade ter surgido com um baixo índice, em ambas as questões. Quais motivos levariam os sujeitos nessa faixa etária, a não dar importância à honestidade? Por que os professores não conseguiram transmitir o valor da honestidade para estes estudantes? Quais fatores estariam influenciando nos sujeitos? Ou este é um valor pouco assimilado / percebido pelos sujeitos nesta faixa etária? 
Comparando esses valores percebidos e sentidos pelos estudantes, por ordem decrescente de ocorrências, temos:
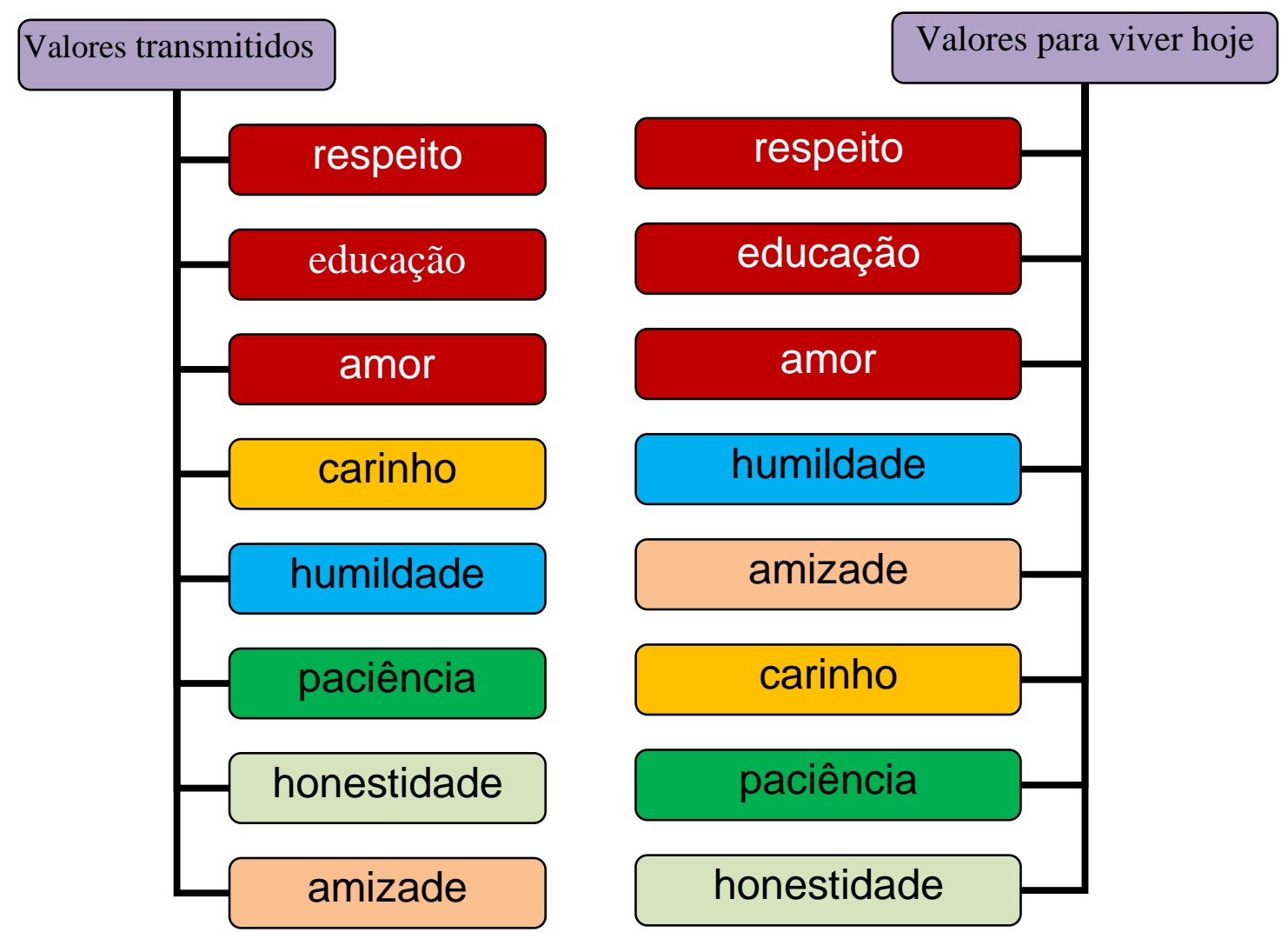

Quadro 4: Comparativo de valores percebidos e sentidos pelos alunos, conforme questões abertas.

Percebe-se que o valor do respeito foi o de maior índice nos dois casos, 19,12\% e 19,78\%, respectivamente, seguidos de educação e amor com índices próximos.Desses valores a amizade não é percebida pelos estudantes, ou seja, os estudantes não sentem uma maior aproximação dos professores como amigo(a)s $(3,27 \%)$, bem como requer maior reflexão é sobre o significado de aprendizagem.

Outros valores citados como transmitidos pelos professores foram a solidariedade com 2,18\%; a sabedoria 1,63\% ; a sinceridade e a fraternidade com 1,09\% cada. Também surgiram valores como, ética, gentileza, consideração, compaixão, igualdade e harmonia, com $0,54 \%$ cada.

$\mathrm{Na}$ questão dos valores importantes para se viver bem hoje apareceram alegria e solidariedade com 2,13\% cada; harmonia e responsabilidade com 1,60\% cada; compaixão, felicidade, fraternidade, gentileza com 1,06\%; e 0,53\% para bem 
estar, cidadania, companheirismo, consciência, cuidar do meio ambiente, estudar, sinceridade.

\subsection{A trajetória das intervenções pedagógicas/oficinas - IPO}

Lembrando que as turmas dos sujeitos pesquisados obtiveram os menores índices nos tipos motivacionais de universalismo e benevolência da Teoria de Valores de Schwartz, que correspondem aos valores de autotranscendência e que visam à preservação, compreensão e promoção do bem-estar de todas as pessoas, inclusive aquelas com quem se convive, além da natureza e do seu meio ambiente.

As relações interpessoais desses sujeitos se encontravam fragilizadas e destacavam mais os valores que atendiam aos interesses individuais do que os de interesse coletivos.

Lembrando que o problema se configurava na possibilidade da formação de valores pessoais como perspectiva de transformar as condutas dos sujeitos em atitudes e comportamentos ecológicos, para promover a paz entre seus pares e colaborar para a formação de cidadãos autônomos e capazes de agir e se relacionar de forma responsável e sustentável.

Nesse sentido, foram trabalhados os valores de respeito, honestidade, solidariedade, cooperação, presteza, igualdade, amizade, bem-estar, justiça e harmonia. Ressalto que muitos valores foram trabalhados em conjunto para a formação e o desenvolvimento de outros, e que alguns destes estiveram presentes em todas as oficinas, como os valores do respeito e cooperação.

Para as análises das IPO, foram utilizadas folhas com atividades orientadas; as falas e respostas dos sujeitos; as reações e simbologias subjetivas; os apontamentos nos Diários de Campo; os comentários dos envolvidos na comunidade escolar (estudantes, professores e direção); as observações participantes e as Rodas de Conversa. 
Sobre as dinâmicas, todas foram vivenciadas em equipes com o cunho cooperativo, e vários foram os objetivos trabalhados e alcançados nessas dinâmicas:

- os sentimentos positivos em relação aos outros colegas, buscando ressaltar as potencialidades de cada um dos participantes, favorecendo a autoestima pelo reconhecimento das virtude que cada um possui, visando criar harmonia entre os estudantes, e promover ajuda na busca das qualidades dos outros;

- o despertar do espírito de equipee as relações de cooperação;

- o respeito e a ajuda ao próximo;

- o cumprimento de regras e normas em nossa vida, incluindo a escola.

- a integração entre os estudantes, refletindo sobre a amizade;

- o sentimento de paz e bem estar pessoal.

Detectado o problema, as intervenções pedagógicas-oficinas - IPO foram planejadas com o foco nas dinâmicas de convivência; no trabalho em equipe; na percepção do respeito e ajuda ao próximo; no despertar da solidariedade e do fortalecimento das relações no coletivo.

Para melhor compreender as atividades desenvolvidas e seus respectivos valores, as dinâmicas foram representadas em 05 categorias, com o foco centrado nos objetivos comuns:

\begin{tabular}{|c|}
\hline $\begin{array}{c}\text { Percepções do quanto conhecemos, ou não, um } \\
\text { colega da turma }\end{array}$ \\
\hline O foco no trabalho coletivo, um trabalho de \\
formiguinha
\end{tabular}

Quadro 5: Informativo das 05 categorias de valores, para análise qualitativa. 


\section{1‥ Categoria:}

\section{Percepcões do quanto conhecemos, ou não, um colega da turma}

No início a pesquisa os sujeitos participantes das IPO indicaram alertas nas suas relações interpessoais, pois, mesmo sem se conhecer, sem saber o que tinham em comum, seus gostos, seus desejos e suas histórias de vida, suas relações estavam estremecidas. Algumas dinâmicas foram trabalhadas na percepção do quanto conhecemos, ou não, um colega de turma.

Na dinâmica da $1^{\underline{a}} \mathrm{IPO}$, a atividade teve como objetivo verificar o quanto nós temos em comum (os mesmos gostos), ou não, com os colegas de classe. Num 1 - momento os estudantes receberam uma folha (apêndice $C$ ), com duas questões e responderam, sem se identificar, a primeira questão "o que eu mais gosto de fazer é ...", e em seguida, no $2^{\circ}$ momento, as folhas foram redistribuídas para outros colegas responderem a $2^{\mathrm{a}}$ questão "diga se você também gosta de fazer, ou não, o que está escrito na questão anterior".

Durante a atividade os estudantes estavam ao lado de colegas por afinidades, razão pelo qual, no $1^{\circ}$ momento, surgiram algumas conversas paralelas e brincadeiras típicas de alunos desinteressados; outros com dificuldades em completar a frase, compartilhando o que estavam escrevendo; alguns ficaram preocupados com o que escreveram; outros disseram ter vergonha em expor seus fazeres; outra aluna pediu que não lessem sua folha; algumas risadas e comportamentos típicos de uma turma com hábitos no descumprimento de regras e normas de conduta numa sala de aula. No 2o momento, após a redistribuição das folhas, um aluno começou a ler em voz alta o que estava escrito na folha que receberá; outros começaram a rir muito ao lerem as respostas das questões. Ao término deste encontro as turmas demonstraram dificuldades em aceitar a tarefa e foram cansativas em relação ao trabalho apresentado. Algumas respostas foram lidas pelo pesquisador e comentadas pela turma. Segue quadro com algumas respostas colhidas nas folhas: 


\begin{tabular}{|l|l|}
\hline $\begin{array}{l}\text { Aluno 1 - Primeira questão: } \\
\text { O que eu mais gosto de fazer é ..... }\end{array}$ & $\begin{array}{l}\text { Aluno 2 - 2a . Questão: } \\
\text { Diga se você também gosta de fazer, } \\
\text { ou não, o que está escrito na questão } \\
\text { anterior: }\end{array}$ \\
\hline $\begin{array}{l}\text { Mexer no facebook, no whatsApp, comer } \\
\text { e dormir }\end{array}$ & Não, mesmo. \\
\hline $\begin{array}{l}\text { Curte rock, fumar, beber e fazer sexo e } \\
\text { andar de skate. }\end{array}$ & $\begin{array}{l}\text { Não gosto de fazer as coisas que estão } \\
\text { listadas acima. }\end{array}$ \\
\hline $\begin{array}{l}\text { Ouvir música, cantar, sair pra me divertir, } \\
\text { navegar na internet, fazer amizades, ter } \\
\text { aula de matemática, etc. }\end{array}$ & Sim menos ter aula de matemática. \\
\hline $\begin{array}{l}\text { Eu gosto de jogar bola, dormir, mexer na } \\
\text { internet, ouvir música, assistir TVe } \\
\text { filmes. }\end{array}$ & Tipo isso. \\
\hline $\begin{array}{l}\text { Mexer no celular, comer, ouvir música, } \\
\text { dormir, sair com os amigos(a). }\end{array}$ & $\begin{array}{l}\text { Gosto de mexer no celular, comer, ouvir } \\
\text { música, não gosto de sair com os amigos } \\
\text { (até porque eu quase não tenho). Só. }\end{array}$ \\
\hline $\begin{array}{l}\text { Jogar futebol. } \\
\text { Sim. }\end{array}$ \\
\hline $\begin{array}{l}\text { Escutar rock, fumar erva, fazer sexo, } \\
\text { andar de skate, tocar (guitarra, bateria), } \\
\text { beber, comer, dormir. }\end{array}$ & $\begin{array}{l}\text { Não gosto de fazer nada que estão ali em } \\
\text { cima, além de comer e dormir. }\end{array}$ \\
\hline
\end{tabular}

Quadro 6: Percepção dos alunos sobre os colegas, durante a 1‥ IPO

Nesta intervenção foram analisadas 56 folhas com 02 questões e em nenhuma delas foi encontrado respostas com desrespeito ou "zombarias" escritas sobre os olhares dos outros colegas, ao contrário, continham respostas espontâneas e autênticas.

Fato este demonstra o respeito com o olhar do outro e a honestidade nas respostas encontradas, principalmente quando responderam sobre "o gosto de fazer a mesma coisa (ou não)" que um colega relatou.

Após a atividade, montamos uma roda de conversa, e dialogamos:

Pesquisador: - Por que muitos tiveram dificuldade em responder a pergunta inicial? Quase todos responderam: - Porque são muitas coisas que gostamos de fazer.

Pesquisador: - E por que tiveram receio de entregar as folhas e compartilhar com os colegas o que você gosta de fazer?

Muitos alunos: - Porque tenho vergonha! 
Pesquisador: - Por que vergonha, já que está apenas dizendo o que gosta de fazer? Aluno(08): - Porque vão gozar de mim.

Aluno(26): - Porque vão rir da minha cara.

Pesquisador: - E isso é certo, é bonito?

Aluno(04): - É falta de educação.

Pesquisador: - Também, mas tem algo a mais nisso.

Aluna(14): - É falta de respeito !

Apesar de ter sido um momento conturbado para alguns sujeitos, pois nunca tiveram suas "falas" expostas, e alguns transtornos durante a dinâmica, os diálogos nas reflexões finais ocorreram com determinada tranqüilidade entre os sujeitos, num clima de aparente "desconfiança", mas com honestidade nas falas transmitidas. Registro que neste primeiro encontro a turma do vespertino demonstrou uma receptividade mais imatura que a do matutino.

Seguindo no objetivo de conhecer melhor os colegas da turma, na dinâmica intitulada "A Entrevista" - a 2 $2^{\mathrm{a}}$ IPO - uns estudantes foram os entrevistadores e outros os entrevistados, sendo observados o respeito e o valor do ser prestativo. A dinâmica permitiu perceber o quanto conhecemos, ou não, um colega que convive conosco o ano todo e verificar o quanto nos falta respeitar uma pessoa que não conhecemos tão bem assim. As duplas foram formadas mediante sorteio, com palavras duplicadas em papeletas dobradas, desfazendo os pares de amizades e convivências oportunas. As palavras utilizadas no "sorteio" foram: amizade, humildade, paz, solidariedade, felicidade, paciência, esperança, respeito, igualdade, cooperação, justiça, sabedoria, bem-estar, honestidade, harmonia, responsabilidade, e dedicação.

Esta atividade contou com 52 participantes e uma folha (apêndice D) que continha 06 perguntas, sendo analisados os itens (a) "O que mais te aborrece na vida?"; (b) "O que Ihe causa grande vontade de viver?"; e (f) "Diga uma coisa que você acha que as pessoas fazem de errado", que foram relevantes para completar o perfil dos sujeitos. 
Para o item (a) "O que mais te aborrece na vida?", predominou a resposta: "pessoas mal educadas e sem respeito", em $42 \%$ das entrevistas.

Para o item (b) "O que lhe causa grande vontade de viver?", predominou a resposta: "meus pais, meus familiares", em $73 \%$ das entrevistas.

Para o item (f) "Diga uma coisa que você acha que as pessoas fazem de errado.", predominou a resposta: "falta de respeito e educação", em $73 \%$ das entrevistas.

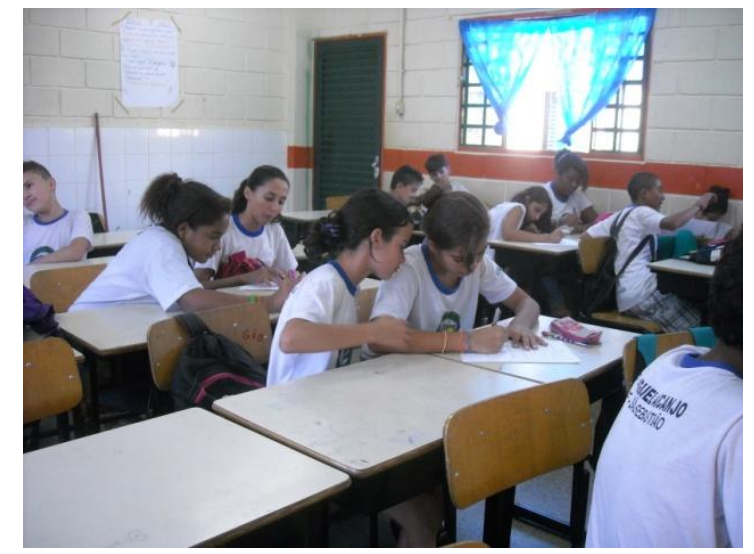

Figura 2: turma do 6ㅇ․ㄹ entrevistas entre os sujeitos

Durante a dinâmica foram observadas situações como o distanciamento entre entrevistado e entrevistador; feições simbolizando dificuldades em responder às questões; muitos estudantes não gostaram de saber que teriam de estar com outro colega fora do seu rol de amizades; e demonstrações de repúdio ao sorteio realizado. Ao término da entrevista, o "gelo" fora "quebrado" e percebi que as duplas interagiam com mais naturalidade.

A análise nesta dinâmica não perpassa pelos resultados estatísticos relatados, mas, pela conduta dos sujeitos em realizar a atividade, mesmo assim, esses resultados não foram descartados, pois apontam que os sujeitos possuem valores autotranscendentes. Nesta trajetória a oficina transcorreu com ressalvas, exercitando situações não vivenciadas nas relações dos sujeitos, sendo visível a diferença de comportamentos da turma do vespertino, mais imaturos, que a do matutino. Em geral, muitos estudantes se encontram com baixa predisposição em aceitar os colegas. 
Durante as atividades alguns valores autotranscendentes se apresentaram nos resultados das tarefas, sendo pouco manifestados durante as relações dos sujeitos nas dinâmicas, mas há, nos relatos acima, indicativos de intencionalidade pelo afloramento dessas ações valorativas.

\section{2‥ Categoria: \\ O foco no trabalho coletivo, um trabalho de formiguinha}

A dinâmica da 5a IPO teve como objetivos exercitar as relações de cooperação e fomentar a solidariedade grupal, impulsionando o trabalho coletivo, propondo que grupos de estudantes montem figuras de quadrados recortados em diferentes tamanhos como um jogo de "quebra-cabeças", distribuídos em envelopes. As regras foram acertadas: apenas um elemento de cada grupo teria que percorrer nos demais grupos e pegar, espontaneamente, uma peça de figura na tentativa de montar a figura do seu grupo, deixando outra. Ninguém poderia retirar peças de figuras já montadas/encaixadas dos outros grupos, e a comunicação entre eles seria através de gestos, finalizando com a montagem da figura do quadrado em equipe.

Relato do panorama durante a atividade: dois estudantes foram resistentes em participar nos grupos; todas as regras foram burladas; muitos estudantes ficaram circulando entre os grupos; alunos retiravam peças já encaixadas nos outros grupos e acumulavam peças sem utilidade para sua montagem; muitas conversas e brincadeiras fora do contexto; uma peça foi rasgada; e o aluno(16), do 6느, fora advertido diversas vezes por condutas inadequadas e ofensas aos colegas. Ao final um grupo conseguiu montar uma figura de quadrado e todos da equipe se levantaram felizes, gritavam por terem vencido e terminado em primeiro lugar, como se a atividade fosse uma disputa entre eles.

$\mathrm{Na}$ roda de conversa discutimos sobre as dificuldades encontradas por não terem concluído a tarefa e as justificativas foram: 
- "Não conseguimos porque tiraram peças da nossa mesa".

- "A turma não "compartilhou" as peças entre os grupos".

- "Faltou organização por parte da turma".

$\mathrm{Na}$ roda de conversa as reflexões emergiram, também, sobre a falta de cooperação e falta de solidariedade entre os colegas. A ausência de ações cooperativas dificultou a montagem dos quadrados.

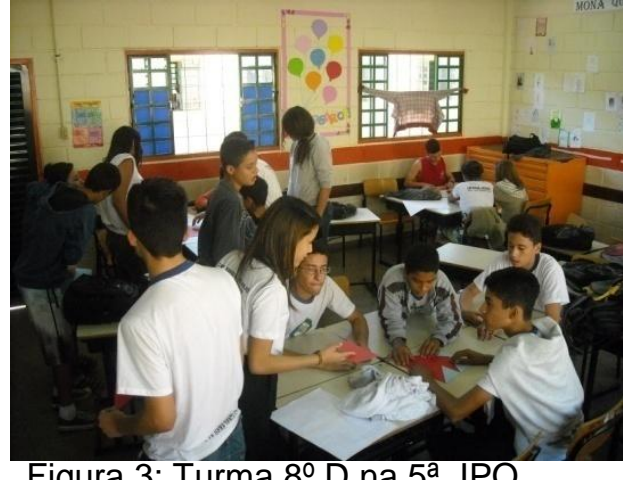

Figura 3: Turma 8‥D na 5‥ IPO

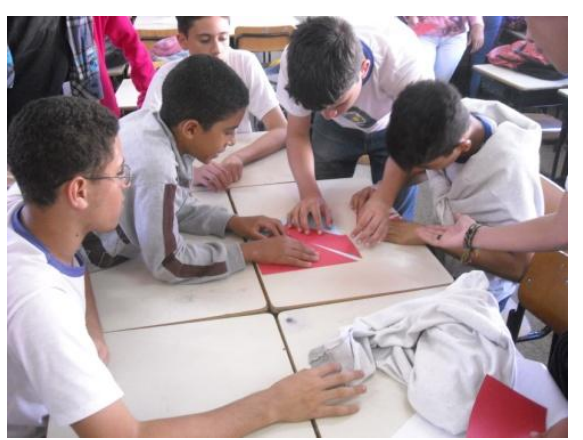

Nesta dinâmica, os sujeitos vivenciaram relações alheias às práticas cotidianas, como cooperação, ajuda mútua com foco no respeito, na paciência, na escuta. Reconheceram o descumprimento de regras.

Figura 4: Turma $8^{\circ}$.D na dinâmica dos quadrados

A dinâmica seguinte continuou com os objetivos de despertar para o trabalho em equipe; estimular a criatividade; refletir na importância que cada um tem para o resultado final de um objetivo comum e no ato de cooperar, sendo realizada em duas partes, 6 a e 7 IPO. A atividade consistia na construção de um desenho coletivo. Inicialmente discutimos sobre o valor da cooperação, que os desenhos seriam em folhas de cartolina, por grupos de 04 a 05 estudantes, e que a escolha desta "criação artística", ficaria sob a responsabilidade dos grupos. As regras consistiam em que a cada sinal do pesquisador, as folhas seriam repassadas pelo grupo para que outros colegas continuassem o desenho a partir do que o colega 
anterior esboçou. Cada participante observaria, sem palpites e em silêncio, o desenho que os colegas conseguiam fazer até chegar a sua vez.

Durante a dinâmica ocorreu que muitos estudantes demoravam a passar a folha para o colega na tentativa de desenhar melhor; outros continuavam desenhando/riscando traços, mesmo com a folha nas mãos do colega anterior; alguns torcendo para que a folha demorasse a chegar ás suas mãos; todos deram palpites nos "riscados" dos outros colegas, burlando regras acertadas. Terminado o horário do encontro sem nenhuma tarefa cumprida, as folhas foram recolhidas para retornarmos à atividade no próximo encontro.

Reiniciando a atividade na $2^{a}$ parte, refletimos sobre as atitudes demonstradas anteriormente, conversamos sobre as regras estabelecidas e a atividade se efetivou. A cada sinal do pesquisador as folhas foram repassadas ao próximo colega; muitos olhares de preocupação com a continuação do desenho; ninguém reteve folhas. Ao término preguei os desenhos no quadro e observamos as "obras produzidas", criticando sobre o cumprimento da tarefa.

Ao final a turma discutiu e concluiu que:

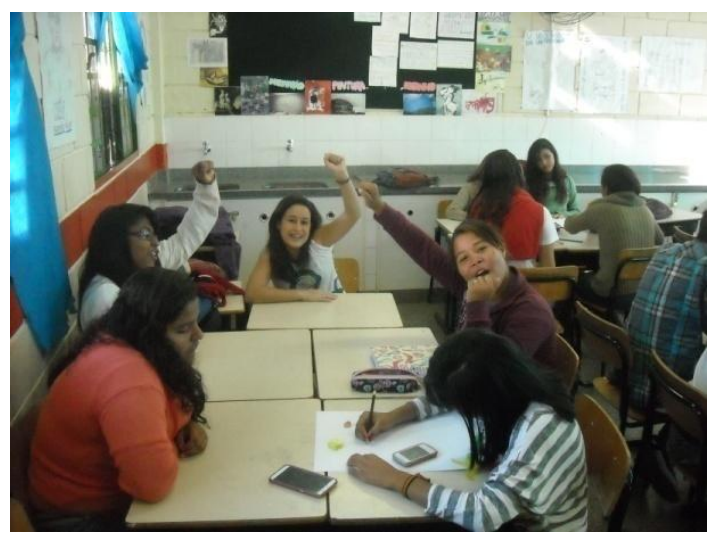

-Todos venceram, não houve perdedor.

-Não ocorreu a tradicional disputa entre as equipes.

-O objetivo era cumprir o que havia acertado em equipe.

-O foco da tarefa não era a estética nos desenhos.

Figura 5: Turma $8^{\circ}$.D na 6‥ IPO

Perguntado a turma sobre o motivo que gerou mais organização para o cumprimento dessa atividade, a aluna(15) respondeu: - "Foi porque o senhor falou dos nossos erros anteriores e agora nós ajudamos um ao outro." 


\begin{abstract}
Lembrei a todos que nesta dinâmica "houve mais cooperação" que na atividade passada. Ao término da aula três alunos continuaram na sala arrumando as mesas e carteiras, num gesto de cooperação e solidariedade.
\end{abstract}

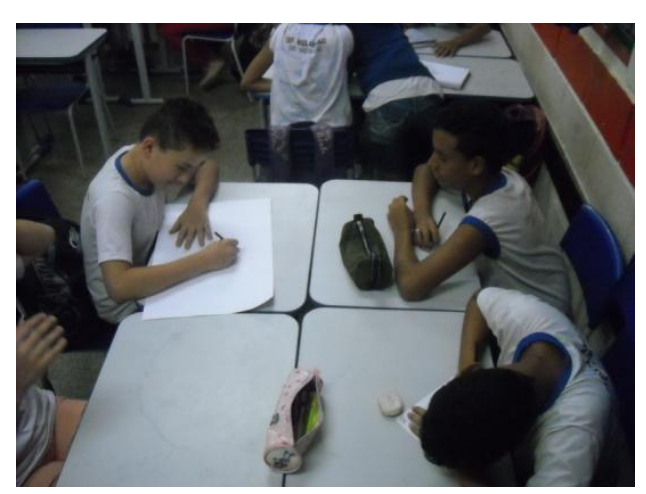

Figura 6: Turma 6ํㅡ na 7ª IPO

Numa outra dinâmica, a 14a․ IPO, objetivando se colocar no lugar do outro, fazendo-os pensar que todos podem estar na mesma situação, e encontrar soluções para alguns conflitos pessoais, os estudantes escreveram numa folha (apêndice E) um problema/conflito pessoal, sem se identificar. As folhas foram redistribuídas aleatoriamente na turma, onde outros colegas deram a solução para o problema/conflito informado. Após a atividade realizada os conteúdos das folhas foram lidos e vários estudantes tentavam adivinhar os nomes dos supostos autores daquela situação, provocando um clima de desconforto com julgamentos precipitados. A turma foi advertida pela "quebra" nas regras, cujo objetivo não era reconhecer nenhum colega, mas ouvir os problemas/conflitos relatados e sugerir novas soluções.

A análise neste contexto não permeou na intensidade/grau dos problemas/conflitos apresentados, mas, e não menos importante, no desrespeito dos sujeitos para a escuta das situações expostas. As respostas contidas nas folhas demonstraram seriedade, clareza, maturidade e sinceridade nas sugestões apresentadas, pelas ausências de comentários desfavoráveis, mas, os diálogos mostraram o descumprimento de regras acordadas. Ao término, organizamos a sala de aula e todos cooperaram em arrumar o ambiente.

A coleta de dados foi realizada em 55 folhas, e como fator ilustrativo, cito alguns problemas/conflitos que surgiram, sendo organizados em 05 subcategorias: $a$ 
aprendizagem escolar; corações apaixonados; conflitos com a autoestima; as tensões familiares; e manifestações da consciência.

Eis alguns problemas/conflitos com a quantidade de ocorrências nas subcategorias:

\begin{tabular}{|c|c|c|}
\hline Subcategorias & $\begin{array}{l}\text { ocorrên } \\
\text { cias }\end{array}$ & Problemas/conflitos \\
\hline \multirow{3}{*}{$\begin{array}{l}\text { A aprendizagem } \\
\text { escolar }\end{array}$} & \multirow{3}{*}{05} & (...) fiquei em uma matéria. \\
\hline & & Não consigo tirar nota boa. \\
\hline & & Estou tirando notas baixas nas matérias. \\
\hline \multirow{7}{*}{$\begin{array}{l}\text { Corações } \\
\text { apaixonados }\end{array}$} & \multirow{7}{*}{10} & Se apaixonar é uma desgraça no mundo. \\
\hline & & Estou apaixonada e não sei o que fazer. \\
\hline & & $\begin{array}{l}\text { Estou querendo namorar só que a menina } \\
\text { não me quer. }\end{array}$ \\
\hline & & $\begin{array}{l}\text { Trai meu ex-namorado e hoje ele não quer } \\
\text { mais falar comigo. O que fazer? }\end{array}$ \\
\hline & & $\begin{array}{l}\text { Gosto de uma menina, mas ela tem } \\
\text { namorada. }\end{array}$ \\
\hline & & $\begin{array}{l}\text { Não encontro uma menina boa que queira } \\
\text { namorar sério. }\end{array}$ \\
\hline & & $\begin{array}{l}\text { Não consigo chegar na pessoa que sou } \\
\text { apaixonada. }\end{array}$ \\
\hline \multirow{8}{*}{$\begin{array}{l}\text { Conflitos com a } \\
\text { autoestima }\end{array}$} & \multirow{8}{*}{10} & Gordura. \\
\hline & & Ser gata demais. \\
\hline & & Estou enjoada de todas as pessoas. \\
\hline & & $\begin{array}{l}\text { Tenho dificuldade em interagir com as } \\
\text { outras pessoas. }\end{array}$ \\
\hline & & Não tenho nenhum problema. \\
\hline & & $\begin{array}{l}\text { Não tenho amigos com que possa contar a } \\
\text { toda hora. }\end{array}$ \\
\hline & & $\begin{array}{l}\text { Minha irmã quando nasceu minha mãe deu } \\
\text { mais atenção a ela. }\end{array}$ \\
\hline & & $\begin{array}{l}\text { Sou muito caladão e não converso com } \\
\text { ninguém da sala de aula. }\end{array}$ \\
\hline \multirow{10}{*}{$\begin{array}{l}\text { As tensões } \\
\text { familiares }\end{array}$} & \multirow{10}{*}{08} & $\begin{array}{l}\text { A relação da minha irmã com meu pai não é } \\
\text { boa (...) }\end{array}$ \\
\hline & & $\begin{array}{l}\text { Trai a confiança da minha mãe, e hoje não } \\
\text { consigo conquistar de novo. }\end{array}$ \\
\hline & & $\begin{array}{l}\text { Fazer com que minha mãe e meu pai se } \\
\text { reconciliem no casamento. }\end{array}$ \\
\hline & & $\begin{array}{l}\text { Ultimamente temos tido brigas lá em casa } \\
\text { com a mulher do meu tio (...) }\end{array}$ \\
\hline & & Meu pai implica com tudo que eu faço. \\
\hline & & Sou chocólatra (...) \\
\hline & & To devendo dinheiro. \\
\hline & & Acordar cedo. \\
\hline & & $\begin{array}{l}\text { Eu fiz uma coisa errada a muito tempo e as } \\
\text { pessoas me julgam até hoje. }\end{array}$ \\
\hline & & Sou gay. \\
\hline
\end{tabular}




\begin{tabular}{|ll|}
\hline $\begin{array}{l}\text { Manifestações da } \\
\text { consciência }\end{array}$ & \begin{tabular}{l} 
To com dor de cabeça e nas pernas. \\
\cline { 2 - 2 }
\end{tabular} \\
& $\begin{array}{l}\text { Descontei a raiva em uma pessoa e queria } \\
\text { fazer as pazes, mas não sei se ela quer. }\end{array}$ \\
\hline Meu problema é briga na escola. \\
\hline $\begin{array}{l}\text { Fico triste porque perdi meu irmão. Choro } \\
\text { muito por isso. }\end{array}$ \\
\hline $\begin{array}{l}\text { Sou viciado no computador e tenho } \\
\text { preguiça. }\end{array}$ \\
\hline
\end{tabular}

Quadro 7: Problemas/conflitos registrados na 14a. IPO

Algumas discussões sobre as respostas/soluções encontradas em cada categoria ocorreram no coletivo, após advertências ao grupo para que respeitassem as situações de cada um como se fossem as suas.

$\mathrm{Na}$ subcategoria 'A aprendizagem escolar', que representou as preocupações com as dificuldades no rendimento escolar, as respostas/soluções foram diretas como se servissem para si próprios:

"Prestar atenção nas aulas e se esforçar mais para tirar notas boas, pois nesse caso só você pode se ajudar."

"Estudar mais essa matéria no próximo bimestre."

“Estude !”

$\mathrm{Na}$ subcategoria 'corações apaixonados', encontramos as decepções e frustrações nos namoros, as respostas/soluções foram ditas com seriedade e respeito ao sentimento do outro. Foram frases (soluções) que perpassaram como "aconselhamentos".

"O problema é se apaixonar, quase $60 \%$ da população se apaixona, mas o apaixonar é um sentimento passageiro, ele vai e volta. Mas o amor não, ele é fixo, não passageiro, duradouro."

"É difícil esquecer o que passou, mais a solução é não falar com ele, deixa isso de lado que com o tempo esquece quanto mais você falar com ele mais triste você fica."

"Tome uma atitude já que você gosta dessa pessoa, sendo ela boa ou ruim vai ser melhor do que ficar na duvida."

"Olha, chega nele e fala que gosta dele, logo se ele não te responder e nem falar com você ele não era a pessoa certa."

"Passa a valorizar, tratar ela com respeito ... essas coisas." 
A subcategoria 'Conflitos com a autoestima', traduz as dificuldades pessoais em lidar com alguns desafios da vida. Eis algumas respostas/soluções:

"Deixar de ser tímida e se soltar mais."

“Entra na academia, para de comer em excesso ... porque ser gorda é (...)"

"Vai pra academia e tenta comer coisas saudáveis."

"Então você acaba de ter um [problema] porque ninguém é perfeito para não ter um [problema]. Você não lembrou do seu?"

"Hoje em dia é difícil encontrar alguém para contar [os problemas]. Mas um dia você vai achar alguém que você possa confiar nas horas boas e ruins, tudo tem seu tempo."

“Tem que ir a um psicólogo."

“É só você conversar mais com as pessoas até eu no começo eu era assim e agora não paro de conversar. Conheça mais as pessoas, isso é uma solução."

"Deixa que depois ela vai te dar atenção."

Todas as soluções apresentadas sinalizam para um sucesso ou fracasso atingidos na busca de afirmações. Isto demonstra a seriedade com que a dinâmica foi efetivada pelos sujeitos.

A subcategoria 'As tensões familiares' resume os conflitos com pessoas de mesmo parentesco. As respostas/soluções foram:

"Só o tempo poderá dizer o que vai acontecer."

"Conversa com a sua mãe, e pede desculpa a ela sobre o que está acontecendo com você."

"Pede ajuda a um especialista, melhor um psicólogo."

"Ficaria calada esperando com que os adultos resolvessem, não discutiria, pois discussão não leva à nada."

"Resolvam conversando com as pessoas que você tem a discussão ou faça igual ao que o professor Lapa fez com a folha nas costas. Quer parar com as discussões?"

“Faça certo e não o errado tente agradar a ele." 
Quanto a subcategoria 'Manifestações da Consciência', representou problemas/conflitos outros cujas soluções são previsíveis tornando a decisão numa ação temporal. Foram estas as respostas/soluções encontradas:

"Se o caso for ir pra escola ou trabalhar, então estuda ou trabalha à tarde. Mas se for seus pais te acordando cedo, então finge que tá doente, perdeu o sono ou então dorme cedo, viu!!!"

"Se estiver dentuço tem que botar mesmo, senão, não coloque cara!"

“Não ligue para 'os outros', viva sua vida, pois como você disse é passado. Se as pessoas te julgam é porque não sabem o quanto você sofre com isso. Peça a Deus para ajudá-lo(a)."

"Sai do armário (...)"

"Reza para que Deus o tenha num bom lugar."

“Para você resolver é só sair e ir brincar na rua, se divertir sem o computador."

"Passa cacau para ficar bom."

"Toma um pequeno remédio para dor de cabeça."

"Vá ao médico. Ele vai te passar um remédio."

“Ė não se meter em confusão."

“Compra um remédio."

"Não viria pra escola se você não conseguisse assistir a aula. Para de ficar correndo ou ficar muito em pé e senta-se."

Nesta etapa, o trabalho no coletivo como os momentos dos diálogos, continua comprometido pela falta de respeito às opiniões e às regras estabelecidas. Os valores em autotrancendência são demonstrados nas atividades individuais como os escritos e respostas em formulários, contrastando com os corriqueiros hábitos pessoais em sala de aula.

\section{3‥ Categoria: \\ O pânico das regras e normas.}

Outro conflito detectado nos sujeitos foi o desconhecimento de regras e normas aplicadas no cotidiano escolar, sendo trabalhado na $11^{a}$.IPO o despertar 
para essas práticas existentes em nossa vida, incluindo a escola. Para tanto foi necessário refletir sobre a tolerância, a cooperação e a escuta às opiniões. Nesta atividade os estudantes se dispuseram a ficar em circulo onde leram bilhetes contendo situações corriqueiras em nossa sociedade e os que não entraram no círculo ficaram sentados em cima das mesas, atentos, comportados, observando e participando das discussões com opiniões sobre cada situação colocada. Ao ler os bilhetes, cada participante detectou a "quebra" de regras e normas propostas naquela situação específica e a discussão ocorreu no coletivo com os diversos olhares sobre o caso.

A análise nesta dinâmica não ocorreu na emissão de valor - certo ou errado - sobre as soluções sugeridas pelos estudantes, mas nas observações das reflexões surgidas, nos comportamentos desses sujeitos, nas posturas dos demais colegas da turma e nas relações construídas na troca das informações. As observações foram registradas em Diário de Campo, e os dados coletados pelas leituras dos bilhetes com respostas/opiniões individuais/coletivas focaram o respeito mútuo, a tolerância, a cooperação, a escuta às opiniões, a harmonia entre os alunos e a ajuda ao próximo e a si mesmo.

Eis algumas das situações propostas com debates calorosos e as respectivas reflexões dos estudantes:

\begin{tabular}{|c|c|}
\hline Situações propostas & Reflexões nas falas dos sujeitos \\
\hline \multirow{3}{*}{$\begin{array}{l}\text { Alguém levou multa por } \\
\text { passar só um pouquinho } \\
\text { da velocidade da rua. }\end{array}$} & $\begin{array}{l}\text { Se não tinha ninguém por perto, sem } \\
\text { problema. }\end{array}$ \\
\hline & $\begin{array}{l}\text {... se ele correu muito quem pagará a multa } \\
\text { será ele }\end{array}$ \\
\hline & ...está errado, pois poderá acidentar alguém \\
\hline \multirow{6}{*}{$\begin{array}{l}\text { Reportagem que saiu na } \\
\text { TV: Uma mãe deixou } \\
\text { criança de } 4 \text { anos aos } \\
\text { cuidados do filho de } 16 \\
\text { anos e a criança, } \\
\text { brincando caiu do 40 } \\
\text { andar, vindo a falecer. A } \\
\text { mãe é culpada? }\end{array}$} & A mãe tem que cuidar da sua criança \\
\hline & $\begin{array}{l}\text {... a mãe não tem culpa pois não estava lá } \\
\text { nessa hora }\end{array}$ \\
\hline & ... foi o irmão quem não cuidou da criança \\
\hline & Sim porque existem garis para limpar \\
\hline & ... se não tiver lixo os garis não terão emprego \\
\hline & $\begin{array}{l}\text {... se jogar lixo no chão a cidade fica mais suja } \\
\text { ainda }\end{array}$ \\
\hline
\end{tabular}




\begin{tabular}{|c|c|}
\hline \multirow{7}{*}{$\begin{array}{c}\text { Se todo mundo joga lixo } \\
\text { no chão por que eu } \\
\text { também não vou jogar. } \\
\text { Tô certo? }\end{array}$} & $\begin{array}{l}\text {... que temos que se preocupar com a situação } \\
\text { do planeta em geral }\end{array}$ \\
\hline & $\begin{array}{l}\text {... "a minha mãe sempre diz que não devemos } \\
\text { ser 'Maria vai com as outras" "“ }\end{array}$ \\
\hline & ... que cada um deve fazer a sua parte \\
\hline & $\begin{array}{l}\text { Acho que sim, senão os garis não vão ter } \\
\text { emprego }\end{array}$ \\
\hline & $\begin{array}{l}\text {... se os garis não tiverem lixo, manda eles } \\
\text { para as escolas que estão precisando }\end{array}$ \\
\hline & $\begin{array}{l}\text {...também acho que os garis ficariam } \\
\text { desempregados }\end{array}$ \\
\hline & $\begin{array}{l}\text { Meu tio mandou eu catar todos os papéis de } \\
\text { balinha que eu tinha jogado no chão }\end{array}$ \\
\hline \multirow[t]{3}{*}{$\begin{array}{l}\text { Estava usando o celular } \\
\text { em sala de aula e o } \\
\text { professor chamou } \\
\text { atenção. } \\
\text { E ai ? }\end{array}$} & $\begin{array}{l}\text { É errado pois não é lugar para usar o celular. } \\
\text { (Obs: A aluna que respondeu foi criticada } \\
\text { pelos colegas que apontaram como praticante } \\
\text { do uso do celular em sala de aula. A aluna(30) } \\
\text { reconheceu que comete este erro. Tem } \\
\text { consciência dessa regra e que não obedece) }\end{array}$ \\
\hline & $\begin{array}{l}\text {... como na lgreja temos que saber se } \\
\text { comportar nos lugares }\end{array}$ \\
\hline & ... é regra da escola e não pode \\
\hline \multirow{5}{*}{$\begin{array}{l}\text { Não gosto de usar o } \\
\text { uniforme da escola e a } \\
\text { direção me chama } \\
\text { atenção. Que } \\
\text { devo fazer? }\end{array}$} & Vestir o uniforme \\
\hline & ... também não gosto porque não é bonito \\
\hline & ... é uma regra da escola \\
\hline & $\begin{array}{l}\text {... uniforme é uma identificação do colégio e } \\
\text { que sou aluno }\end{array}$ \\
\hline & $\begin{array}{l}\text {...quem não gosta, é só vir com outra blusa e } \\
\text { quando a aula acabar troca de blusa }\end{array}$ \\
\hline \multirow{5}{*}{$\begin{array}{c}\text { Eu quero estudar e tem } \\
\text { colegas me atrapalhando. } \\
\text { Que fazer? }\end{array}$} & Pede para parar \\
\hline & ... fala com o professor \\
\hline & ... chama com o Diretor \\
\hline & $\begin{array}{l}\text {... tem gente que até com a direção não para } \\
\text { de conversar }\end{array}$ \\
\hline & ... põe prá fora de sala \\
\hline \multirow{2}{*}{$\begin{array}{l}\text { Você é o chefe no trabalho } \\
\text { e tem funcionários } \\
\text { enrolando e não cumprem } \\
\text { com a função } \\
\text { corretamente, } \\
\text { desconhecendo sua } \\
\text { autoridade. O que fazer? }\end{array}$} & Manda os funcionários embora \\
\hline & ... conversar com eles \\
\hline
\end{tabular}

Quadro 8: Reflexões dos sujeitos na 11a. IPO.

No momento da roda de conversa as reflexões foram proveitosas, quase todos participaram com seus olhares sobre as situações apresentadas e muitos pontos de vista diferentes. Boa parte dos sujeitos do $8^{\circ} \mathrm{D}$ disse que neste dia foi uma "boa aula" e gostaram da atividade desenvolvida.

Ao final, surgiu um diálogo com a aluna(27): 
- Ah! Professor... adoramos essa atividade.

Podemos continuar na próxima aula?"

- Do que mais vocês gostaram?

- Desse momento de poder ouvir todo mundo e saber o que nós achamos!

Sem ter a inocência em pensar que com palavras - sem vivências ocorressem transformações ou formações de novos valores nos sujeitos, a análise e interpretação incidiu sobre o comentário da aluna(27) que traduziu a ansiedade da turma em ter espaço para serem ouvidos e que suas falas foram importantes, procurando o respeito mútuo entre todos, tornando, quase toda atividade, num ambiente de relativa harmonia, com poucas tensões, algumas brincadeiras mas com tolerância aos diferentes pontos de vista, havendo cooperação no desenvolvimento da atividade e no efetivo encontro das ajudas ao próximo e a si mesmo.

Durante 0 desenvolvimento da atividade na turma do 6으, três estudantes foram seguidamente advertidas oralmente por estarem atrapalhando o encontro com comportamentos inadequados, conversas inoportunas e desrespeito ao pesquisador. Interpretar esses relacionamentos conflitantes, também é objeto da pesquisa. Afora esta situação pontual, as discussões foram boas, muitos pontos de vista diferentes, com olhares diferenciados para as regras e normas e estudantes procurando seus erros

Nessa trajetória - vivências com regras e normas - a 18 $18^{\mathrm{a}}$.IPO trabalhou no lúdico, com sentenças indicando comandos, obrigatoriamente iniciados com a palavra $\underline{\mathrm{SE}}$, observando a ocorrência do respeito à opinião dos outros e a harmonia entre todos. Na dinâmica, as respostas dos sujeitos eram submetidas a um determinado comando a ser executado, no qual os erros não foram reforçados.

\section{Exemplos:}

"SE a soma de 2 com 3 for igual a 5, levante a mão direita."

"SE Natal é a capital do Ceará, grite o seu nome."

No $8^{\circ} \mathrm{D}$ os estudantes cumpriram os comandos, acertando ou errando as sentenças lidas, porém, ninguém desrespeitou colegas que erraram nas informações 
respondidas. No 6ㄴ alguns estudantes não entenderam os comandos; outros brincaram com os colegas e fizeram palhaçadas por estarem de pé e descontraídos.

$\mathrm{Na}$ roda de conversa com as turmas, refletimos que, em geral a turma apresentou disposição em cumprir comandos; que todos os sujeitos estão propensos a seguirem regras ou normas, porém, alguns ainda têm resistência em aceitá-las; que na nossa vida temos que seguir determinadas regras, pois vivemos em sociedade, ou seja, no coletivo - sala de aula; que o uso do celular na sala de aula é inadequado e desrespeitoso; que as conversas paralelas tiram o direito de quem quer aprender; que fofocas alimentam discórdias; que algumas regras que achamos "chatas" são necessárias para uma boa convivência em sociedade.

Os valores autotranscendentes começam a emergir nos estudantes, a disposição em aceitar informações perpassa pelas ações desses sujeitos, a tolerância à escuta do outro é lenta, o respeito às opiniões já se faz presente e a busca pela cooperação não têm tantas resistências promovendo o despertar para o cumprimento de regras e normas nas atividades propostas.

\section{4?.Categoria:}

Os sentimentos e sensações percebidas: a busca pelas qualidades dos outros e de si mesmo

As fortes relações antagônicas existentes nas turmas dos sujeitos fizeram com que eles não se conhecessem e não se percebessem que possuem qualidades outras àquelas observadas, portanto, foram trabalhadas dinâmicas que buscaram encontrar qualidades positivas no outro.

Na 3a. IPO, o objetivo foi fomentar na turma sentimentos positivos em relação aos colegas buscando ressaltar suas potencialidades, favorecendo a autoestima pelo reconhecimento das virtudes que cada um possui, visando criar harmonia entre os estudantes, e promover ajuda na busca das qualidades dos outros. Para isso os dados foram coletados em 52 folhas (apêndice F), uma para cada sujeito da turma, entregues nominalmente, contendo em cada folha 12 espaços 
em branco nos quais outros colegas escreveram qualidades positivas para um mesmo sujeito. Estas qualidades positivas foram criadas pelos próprios estudantes analisando o perfil dos seus colegas.

As qualidades citadas foram representadas em 05 subcategorias:

\begin{tabular}{|c|c|}
\hline Subcategorias & Qualidades citadas \\
\hline de estética & bonita(o), linda(o), lindos olhos, glamorosa \\
\hline da moral & $\begin{array}{l}\text { humilde, educada(o), gentil, dignidade, } \\
\text { sincera(o), verdadeiro(a), honesto(a), respeito(a), } \\
\text { leal solidário }\end{array}$ \\
\hline de conduta & $\begin{array}{l}\text { divertida(o), quieto(a), estudiosa(o), tranquilo(a), } \\
\text { disciplina }\end{array}$ \\
\hline da amizade & $\begin{array}{l}\text { gente boa, agradável, sorridente, alegre, } \\
\text { interessante, estiloso }\end{array}$ \\
\hline $\begin{array}{l}\text { do culto ao } \\
\text { negativo }\end{array}$ & bagunceiro, inútil, intolerável, insuportável, feio \\
\hline
\end{tabular}

Quadro 9: Subcategorias dos dados levantados na 3ㅜ․ IPO - qualidades dos sujeitos

Veja o quadro demonstrativo estatístico das qualidades citadas:

\begin{tabular}{|l|c|c|}
\cline { 2 - 3 } \multicolumn{1}{l|}{} & No. de aparições & Porcentagem (\%) \\
\hline \hline $\begin{array}{l}\text { Total de qualidades citadas } \\
\text { pelos sujeitos coletadas nos } \\
\text { instrumentos }\end{array}$ & 598 & $100 \%$ \\
\hline \hline Qualidades positivas & 554 & $93 \%$ \\
\hline \hline Qualidades negativas & 44 & $7 \%$ \\
\hline
\end{tabular}

Quadro 10: Quantitativo das ocorrências das qualidades citadas na 3‥ IPO.

Das qualidades positivas, as que representam estética são $10 \%$, as morais são $14 \%$, as de conduta $34 \%$ e as de amizade, $42 \%$. As qualidades representativas de conduta e amizade perfazem maioria das citadas, demonstrando que os sujeitos têm percepções positivas dos colegas, faltando-lhes oportunidades para se manifestarem. As intervenções pedagógicas na modalidade de oficinas 
promoveram a função de "acordar" e "alertar" os sujeitos de que eles são capazes de olhar para os colegas e descobrir uma pessoa com qualidades positivas.

No próximo encontro, a $4^{\mathrm{a}} \mathrm{IPO}$, continuando a busca pela confirmação das qualidades descritas pelos sujeitos na dinâmica anterior ( $3^{3}$.IPO), foi entregue outra folha (apêndice $G$ ) com as 10 qualidades mais citadas pelos sujeitos. Nesta dinâmica, cada estudante escreveu até 03 nomes de colegas para cada qualidade registrada. Os estudantes sentaram em círculos, entreolhando-se para melhor identificar os colegas. Interessante foi perceber que alguns estudantes apontavam para colegas como querendo saber/lembrar o seu nome, significando desconhecêlo. A dinâmica transcorreu bem, com poucas brincadeiras, isoladas, e após o término solicitei que voltassem a recolocar suas carteias nos seus lugares de forma organizada. Curiosidade: estudantes pediram para continuar com essa atividade num outro momento.

Os resultados obtidos foram semelhantes aos da atividade anterior, ou seja, os registros apresentaram as mesmas freqüências nas qualidades indicadas por seus pares nas duas folhas de atividades. Pode parecer pequeno, porém, é mais um indicativo do reconhecimento das virtudes que cada um possui pelos olhares dos colegas da turma, sendo promovido pelas vivências nas oficinas trabalhadas.

Prosseguindo no objetivo de fomentar nos sujeitos sentimentos de aceitação, autoestima e valorização de sua própria identidade, a dinâmica da 9ª IPO propôs que cada estudante escrevesse numa folha pendurada nas costas dos colegas, características que eles achavam mais importantes em um amigo, mediante as palavras, VERDADE, AMOR, COLABORAÇÃO, LEAL, CONFIANÇA, RESPEITO, CARINHO, SINCERIDADE, HONESTO, CARÁTER, DINHEIRO, HUMILDADE, ENGRAÇADO, citadas pela turma. 


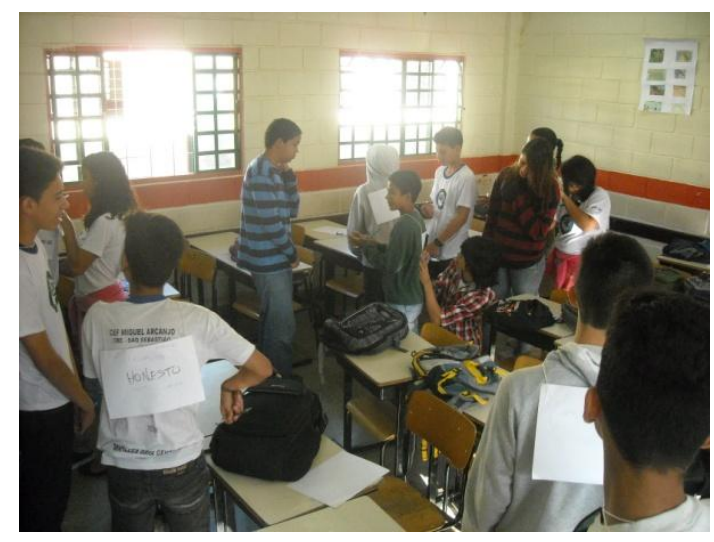

Figura 7 : turma do $8^{\circ}$.D na 9a. IPO
Ao som de uma música suave, os alunos percorreram pela sala de aula escrevendo numa folha pendurada nas costas de cada participante, as qualidades sugeridas por eles.

A análise nesta dinâmica perpassou pelofato de todos os sujeitos terem participado, todos escreveram em algum colega, não houve tumulto, nem gritaria, tampouco conversas ou brincadeiras inadequadase fora do contexto.

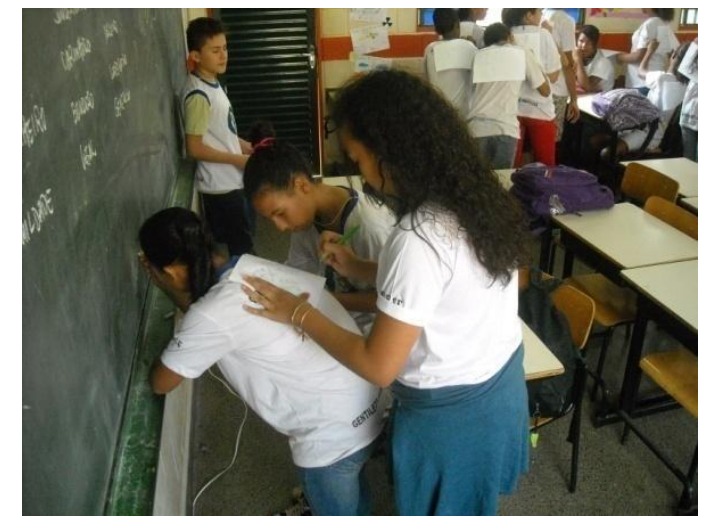

Figura 8: turma do $6^{\circ}$.L na 9a. IPO

Muitos eram os sorrisos estampados com brilho nos rostos. Filas surgiam com estudantes uns atrás dos outros, não ocorreu nenhuma brincadeira "de mau gosto" ou desrespeitosa entre os participantes.O inesperado: muitos estudantes pediram para continuar a atividade na aula seguinte.

Nesta categoria percebeu-se que os valores autotranscendentes começam a desabrochar pelas ações demonstradas. A procura pelo respeito mútuo na aceitação do próximo foi evidenciada na prática, bem como a busca pela cooperação e solidariedade entre os sujeitos desencadearam as ajudas mútuas outrora ocultas nos relacionamentos em sala de aula. A formação de valores pessoais procura ser contínua e permanente na busca pelas melhorias nas convivências do Ser humano. 


\section{5․ Categoria:}

\section{Ensinar a ver o invisível: a harmonia como estratégia lúdica}

Nesta categoria foram exploradas dinâmicas lúdicas cujo foco recaiu no ato cooperativo com os objetivos de despertar o espírito de equipe, a cooperação, o respeito, a harmonia e a ajuda mútua trabalhando a união dos estudantes, criando oportunidades para as práticas de condutas pró-sociais, possibilitando um clima favorável na turma.

Neste olhar, a dinâmica da 8IPO propôs que os estudantes ficassem de pé nas cadeiras, enfileiradas lado a lado, e cujo desafio foi fazer com que todos levassem as cadeiras para outro lugar da sala de aula sem sair delas e sem colocar os pés no chão. Nas 02 turmas trabalhadas foram disponibilizadas 14 cadeiras com 13 alunos participantes -08 meninos e 05 meninas.

A cooperação e ajuda ocorreu desde as discussões sobre quais estratégias seriam usadas para solucionar este desafio. A solução foi encontrada por sugestão de um aluno nãoparticipante e toda a turma vibrou e torceu quando todos os participantes chegaram com ascadeiras no ponto combinado, sem sair delas.

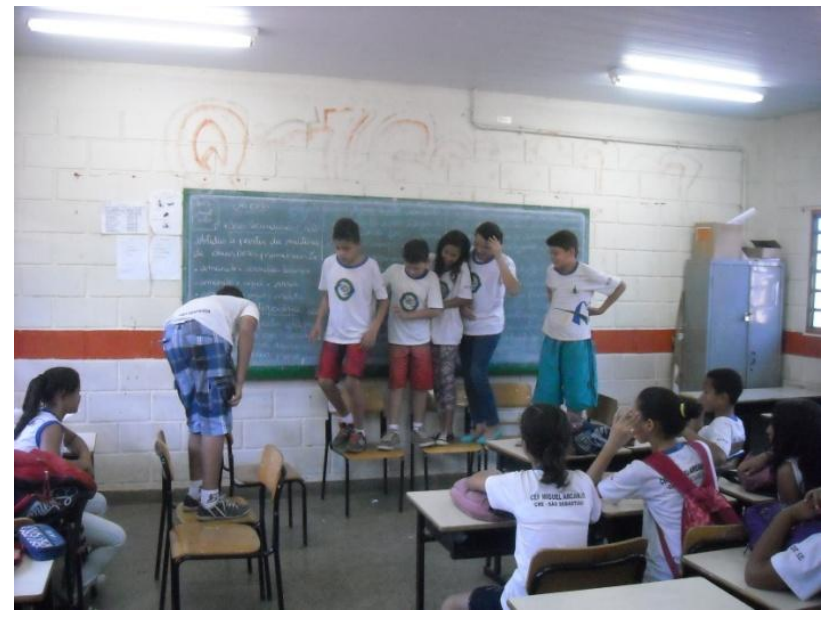

Figura 9: O desafio do Pulo Gigante ( turma do 6ํ…)

Esta atividade ocorreu de forma tranqüila e lúdica, com a participação atenção, sugestões, torcidas - de quase todos os estudantes, indicando a cooperação e as ajudas mútuas necessárias para o cumprimento de uma tarefa realizada no coletivo, de forma prazerosa, invocando brincadeiras, tornando o ambiente e as relações agradáveis. Mesmo nesta atividade, uma aluna insistiu em ficar mexendo/brincando com o celular ligado. 
Finalizando esta atividade perguntei ao grupo de estudantes que ainda estava de pé nas cadeiras:

Pesquisador: - Para vocês, qual o motivo de terem concluído essa tarefa?

Aluno(19): - Foi pela nossa cooperação!

Verifica-se que com dinâmicas lúdicas os sujeitos participam com mais intensidade sem ocorrência da tradicional bagunça e que o comportamento é de respeito e cuidado ao próximo.Com o foco na promoção da união entre os sujeitos, criando harmonia entre todos, ratificando o respeito que deve existir no convívio em uma sala de aula, a 17a .IPO laborou a "dança das cadeiras colaborativas" com a participação de quase $70 \%$ dos estudantes. Para a dinâmica foi explicado que ninguém seria excluído da roda, e que o desafio seria fazer com que todos ficassem sentados no cumprimento da tarefa. Durante a atividade uma cadeira era retirada cada vez que a música parava, e a pergunta era feita a todos: "Dá para continuar ?" Todosrespondiam: "Dáaaaaaaa, pode continuar!!!!" Nenhum estudante saiu da dinâmica até permanecer uma única cadeira no centro da sala. Todos se divertiram e a dinâmica ocorreu com muita alegria e relativa harmonia entre os sujeitos.

Para se ter uma dimensão do ocorrido, relato algumas atitudes interessantes registradas no Diário de Campo:

- No início muitos estudantes ficaram preocupados em "pegar" uma cadeira para sentar, indicando tensão, egoísmo e individualismo;

- Nas 3 primeiras rodadas alguns estudantes ficaram meio receosos em sentar no colo de um outro colega; a partir da $4^{\mathrm{a}}$ rodada muitos estudantes aguardavam, serenamente, para escolher o lugar que iriam sentar.

- Ao término das músicas o estudante (20) caminhava tranquilamente para escolher "onde" iria sentar. Essa atitude era motivada pela segurança de que não sairia da dinâmica. Outros estudantes também externaram essa segurança e tiveram atitude semelhante. 
- Com esta tranqüilidade, meninos sentaram no colo de meninas, meninas no colo de meninos e meninos no de meninos, com a maior harmonia, num clima de paz e respeito.

- Após a música parar, muitos estudantes caiam no chão ou pulavam no colo de outros. Tudo motivado pelo aspecto cooperativo da dinâmica, portanto não havia a preocupação em ser o primeiro ou o último a sentar nas cadeiras.

- A aluna(15) não quis participar da dinâmica, ficando sentada observando tudo e "morrendo" de rir com a descontração dos colegas. As alunas(12) e (14) filmaram toda a atividade.

- O grupo foi até o limite de ter apenas uma única cadeira disponível. Para "matar" a curiosidade, a música tocada foi "Entre tapas e beijos" cantada pela Banda Calypso em ritmo de forró.

Os valores de autotranscendência começam a emergir permitindo que 0 trabalho coletivo tenha sentido nos sujeitos, como promoção do bem-estar da turma; bem como a busca pela cooperação podem transmitirpossíveis mudanças desejáveis nos estudantes, permitindo que o respeito mútuo se faça presente pelas pequenas ações de solidariedade compartilhadas.

As IPO não mencionadas neste trabalho de dissertação perpassaram por uma das 05 categorias relatadas acima.

Após a realização das intervenções pedagógicas-oficinas (IPO) solicitei aos sujeitos que dessem depoimentos espontâneos e anônimossobre as atividades promovidas durante nossos encontros. Os que contribuíram responderam à seguinte pergunta:

\section{"Faça um breve relato sobre as atividades (dinâmicas) desenvolvidas na turma e quais valores transmitidos foram importantes para você ?"}

Os diversos olhares dos sujeitos convergem para um mesmo fim: o reconhecimento e importância dos valores transmitidos através das oficinas.Segue alguns relatos que exprimem as idéias e sentimentos dos sujeitos sobre as dinâmicas desenvolvidas nesta pesquisa: 


\section{Depoimento 1:}

"Eu acho que tudo que foi feito nessa turma ajudou muito para a harmonia e contribuição de toda a turma, um com o outro, eu acho que os professores deveriam fazer essas atividades mais vezes para a turma continuar alegre e colaborando, e nem foi por causa das aulas que ele tirava, foi mais pelas atividades que a turma fazia ... Lapa muito obrigado por ter escolhido nossa turma e obrigado por você ser uma pessoa tão boa, vou sentir sua falta."

\section{Depoimento 2:}

"Mudei meu comportamento com as pessoas, refleti muito sobre o que foi ensinado acho que foi muito importante para mudar minha atitude. Os valores ensinados foi respeito, atitude, caráter, amor, carinho, compreensão. Só acho que ajuda muito a mudar algumas pessoas que pára pra refletir um pouco sobre a vida."

\section{Depoimento 3:}

"Eu gostei muito das dinâmicas, o prof. Lapa é bem educado, paciente, honesto e legal. Eu gostei também porque com esses dias de dinâmicas eu aprendi várias coisas boas e positivas e espero que ano que vem tenha esse projeto outra vez para que outras pessoas possam conhecer essas coisas boas também. Parabéns prof. Lapa."

\section{Depoimento 4:}

"As atividades foram todas ótimas, e maravilhosas, e muito interessantes. Para minha vida os valores transmitidos foram o respeito, amor ao próximo, honestidade, solidariedade. Essas atividades me ajudaram a perceber o quanto existem pessoas que necessitam de nossa ajuda e não sabemos. Hoje posso afirmar que aprendi muito com as dinâmicas. E seria legal se tivéssemos mais aulas desse tipo."

Alguns depoimentos relatam 0 desejo para que atividades como dinâmicas cooperativas possam integrar aos componentes curriculares, permitindo 
que professores trabalhem com valores durante suas aulas, discutindo, refletindo eouvindo os estudantes. Percebe-se, mesmo que timidamente, a procura por uma mudança interior; o fomento pelaformação de valores e a percepção de que boas qualidades fazem parte do crescimento pessoal influenciando e colaborando para o bem estar pessoal e do coletivo.

Durante o percurso das IPO, 02 docentes - um de cada turma pesquisada - teceram comentários relevantes sobre o processo das dinâmicas e o progresso dos sujeitos, gerando depoimentos importantes, como veremos a seguir:

\section{Depoimento do docente 1:}

“Durante os trabalhos realizados na turma do $8^{\circ}$ ano $D$, na matéria Ciências, observa-se gradativa melhora tanto comportamental, quanto relativa ao interesse na área trabalhada.

Os alunos demonstram postura mais receptiva e interessada, bem como deixaram de apresentar apatia, antipatia, “confrontamento" e rebeldia. Mostram-se mais simpáticos e acessíveis.

Observa-se, também, maior entrosamento entre os alunos e destes com o professor, segurança e coerência nas relações interpessoais, sendo possível ministrar as aulas em um ambiente mais tranqüilo e acolhedor.

Vale ressaltar que a turma em análise possuía, no começo do ano letivo, atitudes desrespeitosas, desafiadoras, grosseiras e desinteressadas e que vem, gradativamente, apresentando ganhos positivos nas áreas dos conhecimento e comportamento."

Depoimento do docente 2:

“São Sebastião, 21 de agosto de 2014.

Durante a aula de Português, alguns alunos conversavam sobre as “aulas” do professor Lapa. Ao ouvir a conversa, passei a prestar atenção, no primeiro momento, sem fazer nenhuma intervenção. Os alunos debatiam sobre as atividades que tinham sido feitas no encontro anterior. Um dos alunos, 0 
F.G., falou que não gostava das aulas, que eram chatas. Outro aluno, S.E., o cortou dizendo: "também, você não pára quieto!" $A$ essa altura toda a turma já estava envolvida na discussão. Uns contra, a maioria a favor. $O$ aluno M.M. se sobressaiu nas falas, dizendo: "todos os alunos que estão reclamando, só estão com raiva porque são os que fazem bagunça." Nesse momento, me envolvi na discussão, falando da importância do projeto e do privilégio de ser uma das turmas a participar. Disse-Ihes eu, para que vocês aproveitem essa oportunidade e aprendam a conviver melhor, a se ajudar, pois isso só vai melhorar a convivência da turma. E, dizendo isso, encerrei a discussão. Não é difícil perceber que, mesmo em passos de formiguinha, os encontros com 0 professor Lapa (que os alunos chamam de aula) têm mudado o comportamento do $6^{\circ}$ ano $L$. $E$, acredito que o fato deles estarem conversando a respeito, e não discutindo sem se ouvirem, já é uma prova disso. Como professora, acho de uma importância ímpar, a iniciativa do professor Lapa. Fico muito contente e ele tem todo o meu apoio."

Em ambos os depoimentos há uma clara compreensão de que as oficinas promoveram momentos de harmonia nas atividades. Existem nas falas testemunhos de mudanças de comportamento e o início da formação de novas atitudes entre os sujeitos pesquisados.Consta nos relatos um senso comum de justiça demonstrada pelos sujeitos, mesmo que de maneira primária, concorrendo para a construção de cidadãos honestos e sinceros. Os olhares dos docentes, ainda que precoce, pois os depoimentos ocorreram espontaneamente antes do término dos trabalhos, já premeditavam indicações por resultados positivos das oficinas e as possíveis mudanças que vinham sendo lentamente conquistadas nesta trajetória de pesquisa.

Os frutos desses depoimentos se sustentam nas discussões com os sujeitos sobre o desempenho e execução das atividades propostas. As discussões percorreram pelas dificuldades encontradas no cumprimento das tarefas. No início das IPO muitos sujeitos se mostraram resistentes às dinâmicas e aos poucos foram compreendendo o sentido do trabalho realizado.

Os comportamentos indesejados foram apontados e discutidos com os sujeitos durante as confabulações diárias. Os por quês de suas ações eram constantemente lembrados. Reflexões foram feitas sobre ações inadequadas, onde 
se deu oportunidade de eles se justificarem dos porquês de cada ato, como as brincadeiras desagradáveis, as conversas fora de hora, a falta de respeito entre os colegas, os ataques e insultos gratuitos, o descumprimento de regras e normas, as fofocas e as "quebras" de acordos.

Trechos das falas dos próprios sujeitos durante as IPO apontaram para suas dificuldades:

"- ... foi a falta de respeito que ..."

"- Porque a turma não compartilhou as ..."

“ - ...faltou organização por parte da turma.”

Algumas mudanças foram gradativamente observadas pelo pesquisador $\mathrm{e}$ a possibilidade de transformações foram ressaltadas pelos próprios sujeitos a partir do momento que conseguiram, espontaneamente, expor suas idéias com respeito e segurança. Eis alguns trechos das falas:
"- ...concluímos a tarefa devido a nossa cooperação!"
"- duas virtudes devem ter em qualquer profissão: a paciência e 0 respeito."
"...professor, gostaria que continuasse com as leituras das folhas, pois quero saber o que responderam sobre meu problema!"

"- Ah! Professor .... adorei essa atividade. Podemos continuar na próxima aula?"

"-...gostamos mais desse momento de poder ouvir todo mundo e saber o que nós achamos!"

A partir de um determinado momento o foco nas rodas de conversa foi sobre os bons resultados nas ações desenvolvidas pelas turmas, verificando que boa parte dos sujeitos exercitava a "escuta sensível"; levantava a mão para responder; pedia licença e permissão para sair da sala de aula; falava um pouco mais baixo com os colegas; foram mais atentos aos comandos de 'silêncio'; mostraram-se mais carinhosos com o mediador; mantinham-se mais centrados nas tarefas; procuraram ser menos resistentes às regras e normas; e mais participantes nas ações cooperativas. Estes resultados favoráveis surgiram de forma lenta, gradativa e contínua. Pelo pouquíssimo espaço temporal onde as vivências 
ocorreram, há indícios de que as transformações são possíveis e valores de autotranscendência podem ser incorporados às práticas escolares dos sujeitos.

\subsection{Pós-IPO: os valores pessoais dos sujeitos participantes da intervenção pedagógica}

Após a realização das IPO e a aplicação do $2^{\circ}$ questionário nos sujeitos participantes da pesquisa, apresento a seguir numa tabela comparativa, as novas médias e suas respectivas modas correspondentesem cada item, bem como as do 1ำ questionário.

1) Pensar em novas idéias e ser criativa é importante para ela. Ela gosta de fazer coisas de maneira própria e original.

2) Ser rica é importante para ela. Ela quer ter muito dinheiro e possuir coisas caras.

3) Ela acredita que é importante que todas as pessoas do mundo sejam tratadas com igualdade. Ela acredita que todos deveriam ter oportunidades iguais na vida.

4) É muito importante para ela demonstrar suas habilidades. Ela quer que as pessoas admirem o que ela faz.

5) É importante para ela viver em um ambiente seguro. Ela evita qualquer coisa que possa colocar sua segurança em perigo.

6) Ela gosta de novidade e mudança, sempre tenta fazer coisas novas. É importante para ela fazer várias coisas diferentes na vida.

7) Ela acredita que as pessoas deveriam respeitar as normas. Ela acredita que as pessoas deveriam sempre seguir as regras, mesmo quando ninguém está observando.

8) É importante para ela ouvir as pessoas que são diferentes dela. Mesmo quando não concorda com elas, ainda quer entendê-las.

9) É importante para ela ser humilde e modesta. Ela tenta não chamar atenção para si.

10) Para ela é importante aproveitar a vida. Ela gosta de divertir-se.

11) É importante para ela tomar suas próprias decisões sobre o que faz. Ela gosta de ser livre para planejar e escolher suas atividades.

\begin{tabular}{|c|c|c|c|}
\hline \multicolumn{2}{|c|}{$\begin{array}{c}\text { ANTES } \\
\text { das IPO }\end{array}$} & \multicolumn{2}{c}{$\begin{array}{c}\text { DEPOIS } \\
\text { das IPO }\end{array}$} \\
\hline Médias & Moda & Médias & Moda \\
\hline 4,14286 & 4 & 4,41304 & 4 \\
\hline 2,28571 & 1 & 2,93478 & 1 \\
\hline 5,03175 & 6 & 5,11111 & 6 \\
\hline 3,90323 & 4 & 4,06522 & 5 \\
\hline 4,26984 & 6 & 4,48889 & 6 \\
\hline 4,60317 & 6 & 4,65217 & 6 \\
\hline 3,0000 & 1 & 3,28261 & 5 \\
\hline 3,76619 & 4 & 4,15217 & 5 \\
\hline 4,04762 & 6 & 4,45652 & 6 \\
\hline 5,24194 & 6 & 5,52174 & 6 \\
\hline 4,34921 & 6 & 4,3913 & 5 \\
\hline
\end{tabular}


12) É muito importante para ela ajudar as pessoas ao seu redor. Ela quer cuidar do bem-estar delas.

13) Ser muito bem-sucedida é importante para ela. Ela gosta de ser admirada pelas pessoas.

14) Para ela é importante a segurança. Ela gosta de sentir-se segura na vida.

15) Ela gosta de se arriscar. Ela está sempre procurando aventuras.

16) É importante para ela se comportar sempre corretamente. Ela quer evitar fazer qualquer coisa que as pessoas possam achar errado.

17) É importante para ela estar no comando e dizer aos demais o que fazer. Ela quer que as pessoas façam o que manda.

18) É importante para ela ser fiel a seus amigos. Ela se compromete com eles.

19) Ela acredita firmemente que as pessoas deveriam preservar a natureza. Cuidar do meio ambiente é importante para ela.

20) Fazer as coisas da maneira como sempre foram feitas é importante para ela. Ela busca a tradição em sua vida.

21) Ela gosta de divertir-se pelo prazer que the proporciona. Ela fica feliz em aproveitar a vida.

\begin{tabular}{|l|l|l|l}
\hline 4,20968 & 5 & 4,1087 & 5 \\
\hline 3,74603 & 5 & 4,13043 & 6 \\
\hline 4,84127 & 6 & 4,36957 & 6 \\
\hline 4,14286 & 6 & 4,15217 & 6 \\
\hline 3,31746 & 1 & 3,17391 & 1 \\
\hline 2,49206 & 1 & 2,41304 & 1 \\
\hline 4,7619 & 6 & 5,43478 & 6 \\
\hline 4,28571 & 4 & 4,47826 & 6 \\
\hline 3,30159 & 5 & 3,32609 & 4 \\
\hline 4,90476 & 6 & 5,23913 & 6 \\
\hline
\end{tabular}

Tabela 8: Médias e Moda dos sujeitos participantes ANTES e DEPOIS das IPO - 6‥L e 8‥D

Nesta tabela comparativa, as maiores médias significam que os sujeitos participantes se identificaram nas descrições com os seus valores pessoais.

A primeira análise a ser feita é quanto ao crescimento nos índices das médias dos valores de autotranscendência, objeto da pesquisa, indicando que os sujeitos buscam a igualdade a todos; o ser prestativo; a harmonia e a lealdade aos amigos, contendo um dos maiores acréscimos. Interessante verificar a disposição dos sujeitos em concordar com a proteção ao meio ambiente, pois, neste item obtivemos mais adeptos com maior freqüência, qual seja, "se parece muito comigo". Houve um acréscimo considerável na média do valor correspondente ao respeito, indicando que mais sujeitos procuram se identificam neste item.

Outra importante análise recai nos tipos motivacionais de realização onde, antes das IPO, os sujeitos não davam importância ao sucesso pessoal através de demonstração de competência. Após as oficinas, os participantes procuram demonstrar serem bem-sucedidos estando preocupados com a sua 
imagem diante do grupo. Esse novo olhar é justificado pelas demonstrações de capacidade no enfrentamento dos desafios impostos pelas dinâmicas.

Permanecem quase que inalteradas as médias e as modas dos valores relacionados ao tipo autodeterminação, indicando que os sujeitos continuam dando importância à busca pela independência e pelas escolhas dos próprios objetivos. Os sujeitos continuam se identificando com os valores do tipo estimulação, característicos pela ousadia, novidades e ter uma vida variada com desafios à frente. Os valores relacionados ao tipo poder continuam apresentando médias baixas, indicando que os estudantes não consideram importantes ser ricos, nem influenciar e controlar outras pessoas.

Fato interessante se apresenta no olhar à obediência em seguir as regras e respeitar as normas, pois os resultados demonstram que, anteriormente às IPO, os sujeitos se identificavam com a descrição "não se parece nada comigo", e posteriormente às oficinas, há uma alteração para a identificação com "se parece comigo", sugerindo que mais sujeitos buscam se adaptar às normas. Esta disposição deve-se aos intensos diálogos nas rodas de conversa a respeito dos comportamentos demonstrados nas dinâmicas. Porém, no valor de autodisciplina, versando sobre a importância de se comportar sempre corretamente, os sujeitos mantiveram a descrição "não se parece comigo" desvencilhando o ato de obediência às regras e normas, ao fato de fazer coisas que as pessoas possam achar errado.

Os sujeitos continuam se identificando com os valores que se remetem a "curtir a vida", fazendo parte das suas aspirações, que são valores associados ao hedonismo, porém, também mantém o desejo da harmonia como motivação à sobrevivência das amizades, com estabilidade nos relacionamentos interpessoais. Ao mesmo tempo em que os sujeitos desejam aproveitar a vida com emoções e novidades, procuram aceitá-la com humildade e cientes dos seus limites.

Após a realização das IPO e a aplicação do $2^{\circ}$.questionário nos sujeitos da amostra, a configuração dos tipos motivacionais de valores também foi feita pela análise da estrutura de similaridade (Smallest Space Analysis - SSA) que é uma forma não métrica de análises de escalonamento multidimensional (EMD). Neste 
2ำ mapa, doravante intitulado Mapa do EMD (II) para os sujeitos participantes das IPO, encontramos os pontos bem distribuídos, colocando os tipos motivacionais em equilíbrio. É nítido as posições das dimensão em regiões bipolares de "autotranscendência" versus "autopromoção" e "abertura à mudança" versus "conservação", de acordo com o Mapa do EMD (II):

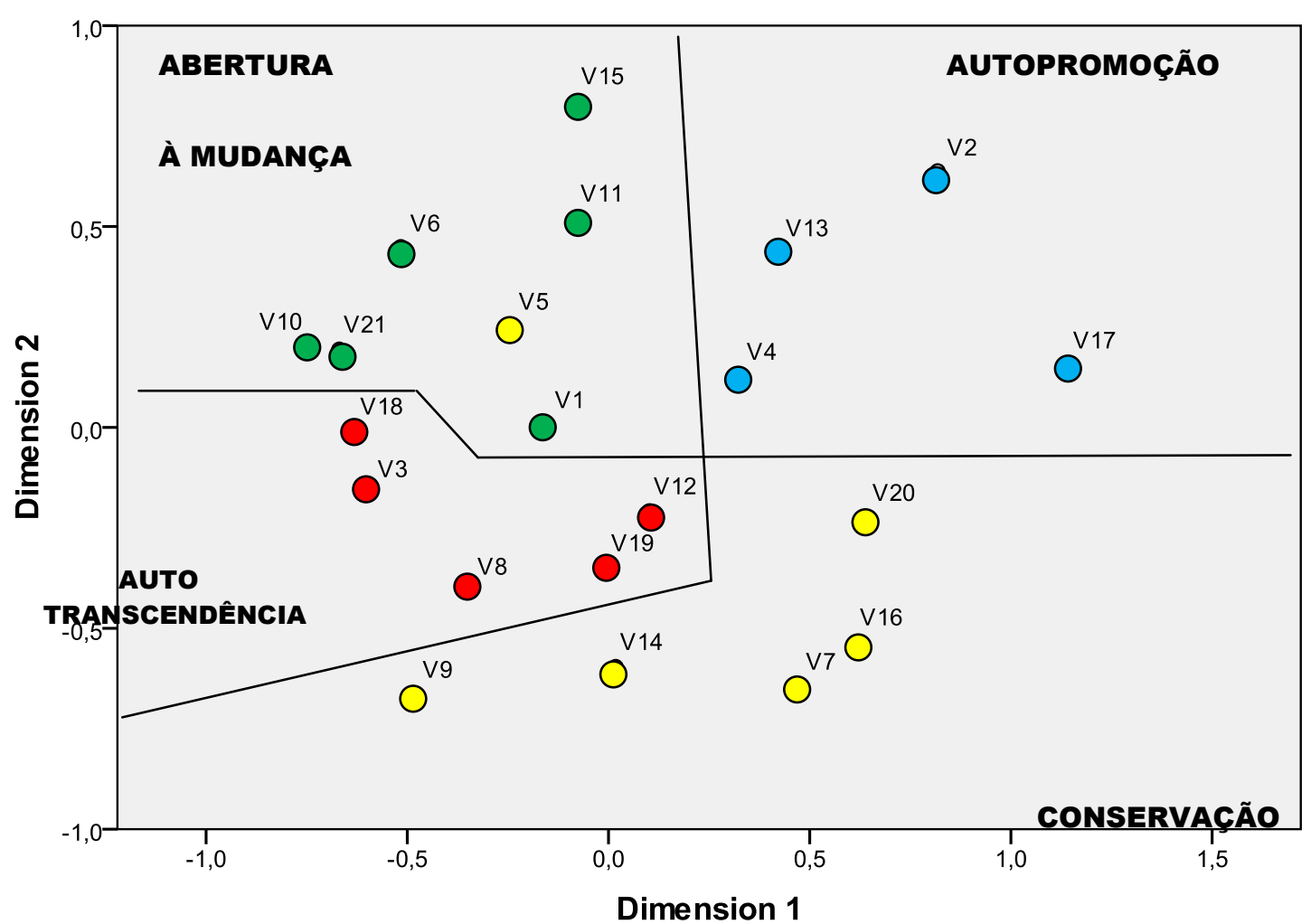

Figura 10: Mapa do EMD(II), após término das IPO e aplicação do $2^{\circ}$ questionário.

Todas as dimensões estão com seus tipos motivacionais agrupados e congruentes, sem o surgimento de nenhum outro valor a ser agregado, com exceção da dimensão "conservação" que teve um tipo motivacional de segurança migrado para a dimensão oposta "abertura à mudança". 
Para uma análise comparativa nas turmas dos sujeitos pesquisados $-6 \div$. . e $8^{\circ} . \mathrm{D}$ - antes e depois das IPO, foram calculadas as médias na dimensão "autotranscendência" (benevolência e universalismo) e nas demais dimensões, conforme demonstrado na tabela abaixo:

\begin{tabular}{lcc}
\hline \multicolumn{1}{c}{ Dimensões } & Médias & Médias \\
& 1.questionário & 2.questionário \\
\hline Autotranscendência & 4,41083 & 4,65502 \\
Abertura à mudança & 4,55026 & 4,72826 \\
Conservação & 3,7963 & 3,83333 \\
Autopromoção & 3,09127 & 3,38587 \\
\hline Tabela 9: Médias nas dimensões dos sujeitos da amostra, ANTES e DEPOIS das IPO
\end{tabular}

Verifica-se um aumento na média de "autotranscendência", foco desta pesquisa, significando que os sujeitos estão se preocupando um pouco mais com o bem-estar dos colegas; que os laços de amizades estão se estreitando; que começam a acreditar na igualdade de todos; e ter um pouco mais de respeito ao que outras pessoas possam thes dizer. Este acréscimo é representativo das vivências ocorridas durante as dinâmicas realizadas ocorrendopequenas mudanças nas relações interpessoais dos estudantes.

A busca pela independência nas atitudes e ações desenvolvidas nas IPO, promovidas pelas vivências com novidades e criatividades, acrescidas de prazer e gratificação no compartilhamento das idéias e pensamentos para o fortalecimento de amizades mais verdadeiras, pode ser significativo desse acréscimo na média em "abertura à mudança".

O acréscimo na média da "conservação" pode ter sido determinado pela percepção de segurança na cumplicidade dos colegas permitindo que uma conveniente sensação de harmonia estivesse presente nos encontros das IPO, com respeito às opiniões e pensamentos 
O aumento na média da "autopromoção" pode ter sidomotivado pelo fato de boa parte dossujeitos ter se empenhado nas dinâmicas, ora buscando prestígio na turma, ora demonstrando competência nas tarefas realizadas, mas todos buscaram o sucesso pessoal característicos da faixa etária estudada.

Calculadas as médias de todos os itens representativos dos tipos motivacionais apresentados no $2^{\circ}$ questionário, obtivemos a maior média no item V10 do tipo motivacional hedonismo, com a frase "Para ela é importante aproveitar a vida. Ela gosta de divertir-se." característico dos sujeitos estudados.

Tendo como base essa maior média, foram realizados os cálculos do desvio padrão em todos os itens, para verificar a dispersão entre os demais valores. Segue quadro com as médias dos tipos motivacionais e seus respectivos desvios padrão:

\begin{tabular}{|l|l|l|c|}
\hline Itens & Médias & $\begin{array}{l}\text { Desvio } \\
\text { Padrão }\end{array}$ & $\begin{array}{l}\text { Dispersão em } \\
\text { relação à V10 }\end{array}$ \\
\hline V1 & 4,413043 & 1,59956 & menos disperso \\
\hline V2 & 2,934783 & 3,12303 & mais disperso \\
\hline V3 & 5 & 1,47826 & menos disperso \\
\hline V4 & 4,065217 & 2,06625 & \\
\hline V5 & 4,391304 & 1,78916 & menos disperso \\
\hline V6 & 4,652174 & 1,68895 & menos disperso \\
\hline V7 & 3,282609 & 2,70248 & mais disperso \\
\hline V8 & 4,152174 & 2,02279 & \\
\hline V9 & 4,456522 & 1,96496 & \\
\hline V10 & 5,521739 & & \\
\hline V11 & 4,391304 & 1,86816 & \\
\hline V12 & 4,108696 & 2,01249 & \\
\hline V13 & 4,130435 & 2,25669 & mais disperso \\
\hline V14 & 4,369565 & 1,96592 & \\
\hline V15 & 4,152174 & 2,25648 & mais disperso \\
\hline V16 & 3,173913 & 7,91683 & mais disperso \\
\hline V17 & 2,413043 & 2,81369 & mais disperso \\
\hline V18 & 5,434783 & 0,65362 & menos disperso \\
\hline V19 & 4,478261 & 1,85077 & \\
\hline V20 & 3,326087 & 2,67789 & mais disperso \\
\hline V21 & 5,23913 & 1,14249 & menos disperso \\
\hline
\end{tabular}

Quadro 11: Médias e os desvios padrão dos itens do $2^{\circ}$ questionário. 
No Mapa do EMD (II) do 2 questionário, observamos pelos desvios padrão calculados, os itens que estão mais próximos (menos dispersos) e os mais distantes (mais dispersos) de V10.

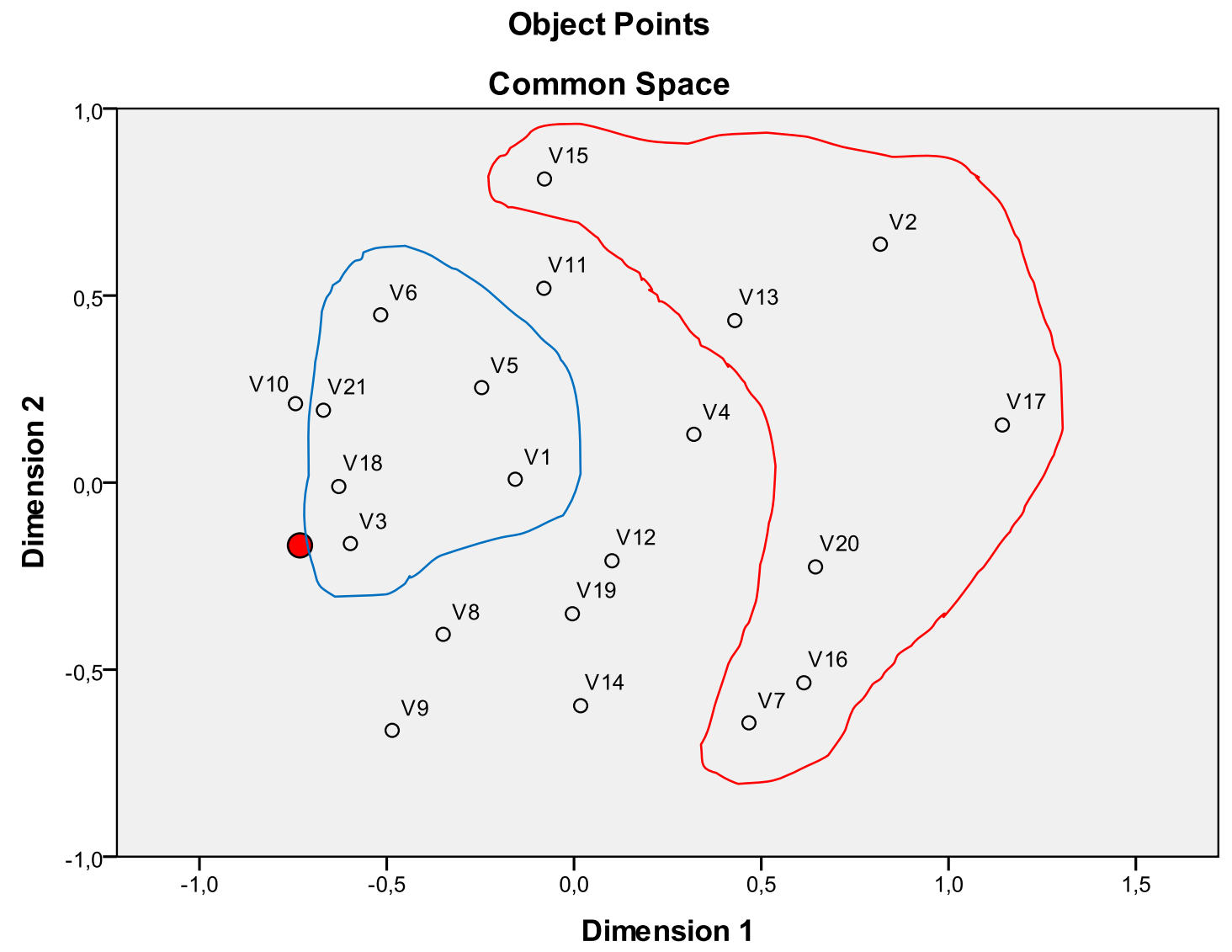

Figura 11: Grau de dispersão dos desvios padrão no EMD (II)

A homogeneidade nos pontos menos dispersos sugere a importância que os sujeitos dão no valor de curtir a vida, fazendo as coisas da sua própria maneira, procurando novidades, tratando a todos com igualdade sem perder suas amizades. Nesta faixa etária os sujeitos estão em discordância das questões financeiras, nas projeções sociais e de prestígio, bem como em seguir regras e normas. $O$ interessante é o viver o hoje e o agora.

Calculado os desvios padrão para as dimensões dos tipos motivacionais, verificamos o menor resultado na dimensão autotranscendência, significando maior concentração e menor dispersão de valores; e uma maior dispersão em autopromoção, conforme tabela abaixo: 


\begin{tabular}{|c|c|}
\hline Dimensões & Desvio padrão \\
\hline AUTOTRANSCENDÊNCIA & 1,398509345 \\
\hline CONSERVAÇÃO & 1,661192729 \\
\hline AUTOPROMOÇÃO & 1,811201952 \\
\hline ABERTURA Ȧ MUDANÇA & 1,445406975 \\
\hline Tabela 10: Desvio padrão das dimensões no $2^{\circ}$.questionário
\end{tabular}

Esses dados corroboram com as justificativas expostas anteriormente, representando a disposição dos sujeitos em preservar uma amizade verdadeira; em cuidar do bem-estar dos colegas; em perceber que a não aceitação daqueles que são diferentes causará conflitos nos relacionamentos. 


\section{DISCUSSÕES}

O objetivo desta pesquisa foi identificar os valores de estudantes e desenvolver um processo de formação com ênfase nos menores valores de autotranscendência, por meio de intervenções pedagógicas, em um grupo de estudantes das séries finais do ensino fundamental de uma escola pública na cidade de São Sebastião/DF.

Miranda (2010) diz que o ato de educar é um ato sagrado, objetivando construir uma humanidade altruísta e amorosa. Este foi o olhar tanto do pesquisador, quanto do professor, acreditando na formação de cidadãos livres, honestos, verdadeiros, amigos, sinceros, buscando o respeito mútuo que foi a condição necessária e absoluta para a efetivação das IPO.

É importante registrar que um projeto na escola focado em valores pode atuar nos discentes de forma direta, consciente, vivencial, dialógica, podendo promover mudanças nas atitudes, construindo um ambiente mais harmonioso. Para tanto, docentes, direção e toda equipe auxiliar da comunidade escolar devem participar deste mesmo olhar, assegurando o cuidado e respeito necessários a uma boa educação para os estudantes e para todos.

Pela primeira etapa da pesquisa verificamos que os estudantes já possuem uma disposição aos valores de autotranscendência, visto que seus laços de amizade são fortes e compartilham dos mesmos desejos e afazeres nesta faixa etária. Um primeiro olhar preconiza que os resultados da Teoria de Valores postulada por Schwartz (2005) caracterizam as relações encontradas nos sujeitos estudados. Esta pesquisa teve como base as médias da dimensão autotranscendência, cujos valores indicam a busca do bem-estar das pessoas, prevalecendo o tipo motivacional da benevolência e cuja preocupação encontra-se nas pessoas afetivamente mais próximas, neste caso os colegas da turma, após as IPO.

Para Pato e Tamayo (2002), conhecendo os valores básicos e prioritários das pessoas, poderemos promover mudanças gerais e efetivas em seus 
comportamentos e atitudes. Conhecidos os valores dos estudantes, as oficinas permitiram que os interesses individuais se infiltrassem aos coletivos, ocorrendo uma relativa mudança nas posturas egocêntricas para altruísticas. Esta pesquisa indicou que uma educação centrada em valores que promovem a transcendência dos interesses individuais e egoísticos em favor de interesses mais coletivos e sociais, pode contribuir para a mudança do quadro de conflitos existente na escola.

Verificou-se com este estudo que a prática dos valores humanos na escola pode contribuir para minimizar as ações de violência, tanto de grupos, quanto de indivíduos, envolvendo as condutas inadequadas com os estudantes nas turmas, possibilitando diminuir as agressões entre estudantes/professores e estudantes/família. Uma formação em valores contribuirá para que as atitudes e os comportamentos dos estudantes possam mudar.

A Educação Ambiental está "intimamente associada à formação de valores e atitudes sensíveis à diversidade, à complexidade do mundo da vida e, sobretudo, a um sentimento de solidariedade diante dos outros e da natureza" (CARVALHO, 1998, p.23), estando engajada na construção de uma nova cultura que gera novos comportamentos com formação de sujeitos éticos e políticos, transformando as "relações sociais e culturais que constroem os modos individuais e coletivos de estar no mundo" (CARVALHO, 1998, p.24). Nessa perspectiva, a formação em valores humanos através de oficinas,buscou mudanças nas relações interpessoais dos estudantes, visando melhorar o seu comportamento em relação aos seus pares e ao mundo em que vive (COSTA, 2006).

.As fragilidades encontradas nos relacionamentos dos estudantes são baseadas em um sistema de valores preexistentes demonstrando, muitas vezes, posturas e condutas inadequadas que desequilibram o processo educativo na escola. Pela perspectiva da Ecologia Humana, as ações no cotidiano permitem construir uma nova relação com o outro e uma ampla intervenção humana no meio ambiente, ou seja, nossa ação ou omissão pode afetar positiva e/ou negativamente a outras pessoas, aos animais ou à natureza (SOUZA, 2007). Segundo Souza (2007, p.452) "é importante que o homem repense sua relação consigo, sendo que o mesmo é o primeiro ambiente que precisa ser questionado". 
Pela Ecologia Humana podemos ter uma visão ecológica sobre os problemas humanos, traduzindo-os numa nova forma de olhar para o que nos cerca e poder indicar uma maneira de como as futuras gerações deverão conviver no cotidiano escolar. Souza (2007) lembra que é necessário repensar a nossa posição na natureza, bem como, repensar nossas atitudes acerca do ambiente como um todo. É emergente reconsiderar as relações existentes no ambiente escolar. Uma formação em valores poderá ajudar os estudantes a perceberem a necessidade de mudanças em seus comportamentos e suas condutas, em prol de uma melhor convivência nas comunidades que vivem (COSTA, 2006).

$\mathrm{Na}$ perspectiva de construir um processo educativo que possibilite ao estudante ampliar seus conhecimentos nas dimensões individual, afetiva, social e espiritual, a Educação Ambiental e a Ecologia Humana podem contribuir na transmissão e fortalecimento de valores autotranscendentes (DANSA, PATO, CORRÊA, 2014). Pensando o indivíduo, neste particular o estudante, em permanente formação na sua inteireza, conectando-se à natureza, uma formação em valores autotranscendentes pode possibilitar mudanças nas relações intra e interpessoais desses estudantes nos mais variados ambientes. Pela Ecologia Humana esses sujeitos estão em constante processo de formação e autoformação, envolvendo os aspectos cognitivos, afetivos, motivacionais e relacionais. Nessa ótica, busca-se a construção de sujeitos ecológicos na perspectiva de uma educação focada em valores podendo promover transformações em suas relações e inter-relações.

Esse constante processo de construçãodos sujeitos ecológicos pode ser constituído a partir de valores ecológicos, sendo estes os de autotranscendência que incorporam a dimensão ambiental. A perspectiva da formação em valores ecológicos é a de contribuir para a tomada de consciência, a autonomia e a reflexão crítica, empoderando os sujeitos e incentivando a autoformação, o autoconhecimento e o contínuo crescimento pessoal (PATO, 2011b).

Pelas dinâmicas cooperativas os sujeitos demonstraram que são capazes de perceber qualidades positivas nos colegas, pois estas têm o caráter acolhedor aflorando sentimentos e virtudes antes não observados. As dinâmicas permitiram que os sujeitos trabalhassem com o lúdico, promovendo a descontração, 
favorecendo a naturalidade e originalidade nos diálogos. Para Puebla (1997) as dinâmicas possibilitam vivências, que ao serem refletidas e partilhadas geram um aprendizado pessoal, possibilitando, dentre outras coisas, o exercício de escuta e acolhida do outro; percepção do todo e das partes, tanto da vida como da realidade que nos cerca. As oficinas permitiram que parte dos estudantes explicitasse suas opiniões de forma simbólica e criativa permitindo que nesse processo de relação entre eles $\mathrm{e}$ as vivências propostas, possibilitassem uma nova forma de compreender suas relações interpessoais (CORRÊA, 2011). Uma educação nessa perspectiva ocorre a partir de uma pedagogia vivencial e simbólica (DANSA, PATO, CORRÊA, 2014), trabalhando de forma dinâmica, lúdica, promovendo interações e abordando os conteúdos sob diversos aspectos, tanto individual, quanto coletivamente.

As intervenções pedagógicas na modalidade oficina contribuíram para reflexões sobre as relações interpessoais dos sujeitos, buscando promover mudanças internas e externas. Boa parte deles não possui ciência do que pode ser feito para melhoria nos relacionamentos e respeito mútuos com o outro. Nas procuras pelas ajudas mútuas, o professor/pesquisador auxiliou o grupo de estudantes, corrigindo falas, ouvindo histórias, semeando valores, podendo refletir no desenvolvimento do processo educativo. Puig e Garcia (2010) esclarecem que os professores têm a capacidade de exercer influências positivas sobre os estudantes através da autenticidade nas relações, a coerência nos momentos de agir, permitindo mostrar atitudes pessoais valiosas.

Outra contribuição das oficinas foi a promoção de um espaço criativo, possibilitando aos sujeitos um melhor diálogo entre seus pares, expondo idéias e sentimentos de si próprios e dos outros. Conforme Corrêa (2003) nas oficinas as experiências pessoais "são revistas a partir do processo de relação da pessoa com as vivências propostas, possibilitando uma nova forma de compreender a realidade e nela interferir" (p. 120).

Pelas oficinas, o processo de formação de valores autotranscendentes indicou nos estudantes a busca pela constituição de sujeitos atentos para a prática de bons valores com a finalidade de formar pessoas interdependentes e, conseqüentemente, mais felizes. (MARQUES, 2012). Trilhando na perspectiva de 
bons valores, Marques (2012), cita que a "boa educação divulga o respeito pelo outro e a percepção de que vivemos em comunidade; ajuda a desenvolver uma escuta atenta e respeitosa do outro; estabelece respeito e admiração entre quem manda e obedece - desde que esta obediência seja estabelecida pelo afeto" (p.34).

Indicou também, em boa parte das oficinas, que os sujeitos procuraram o respeito mútuo, sendo observadas em muitas das atividades apresentadas, as ausências de brincadeiras e gozações pejorativas. Durante as atividades, um aparente sentimento de justiça transpareceu existir quando nas discussões e reflexões ocorridas nas rodas de conversa, as opiniões e sugestões dos estudantes foram defendidas e expostas ao grupo. Essas atividades contribuem para que as ligações afetivas entre os sujeitos e entre eles e seu entorno promovam ambientes mais agradáveis, facilitando a aprendizagem e podendo contribuir para o cuidado e a preservação ambiental.

A maneira como os sujeitos vivenciaram valores, afetou grande parte da turma, contribuindo para a eficácia das oficinas. Conforme Costa (2006, p. 20-21), "o exercício dos valores é um meio disponível para promover uma forma mais profunda e harmoniosa de mudança e desenvolvimento humano." Isto ficou evidenciado nos depoimentos dos discentes e docentes, com relatos de tendências em mudanças nos comportamentos e que novas atitudes fizeram com que os sujeitos buscassem perceber outros valores em suas vidas.

O trabalho de formação em valores com estudantes tentou minimizar determinada falta de perspectiva pelas melhorias nas relações interpessoais desses sujeitos. Corroboro com Jalali (2010) quando cita que a humanidade passa por turbulências sociais, desilusões, e que uma pequena parcela de indivíduos, órgãos públicos e privados e outras organizações relacionadas aos segmentos sociais, têm iniciativas orientadas para a reconstrução de uma base humana e institucional. A autora lembra que esta base humana é "sustentada e alimentada por valores e princípios éticos e morais que resgatem o propósito da criação e restabeleçam as virtudes nas relações dos seres humanos com a natureza e com a sociedade" (p.139). É da prática desses pequenos esforços coletivos por parte de uma minoria, comenta Jalali (2010), que a paz para a qual a humanidade está destinada será alcançada. 
Sinto-me parte dessa minoria buscando parcerias para encontrar soluções e sugestões que auxiliem estudantes e profissionais da educação a encontrar caminhos que nos levem a uma convivência mais harmoniosa e prazerosa no ambiente escolar. Esta parceria foi encontrada na Educação Ambiental e Ecologia Humana.

Neste trabalho não foi realizado o Teste $t$ de Student para interpretar de forma mais profunda, os resultados obtidos nas médias dos valores de autotranscendência. Porém, esse relativo aumento nas médias pode significar uma tendência de mudança de comportamento, provavelmente/conseqüentemente, promovido pela formação em valores. Isto é devido às análises qualitativas nos olhares dos estudantes e pelas respostas dos professores. Portanto, há de se ter novos estudos para aprofundamentos no Teste $t$, e proporcionar futuras comprovações nos resultados obtidos. 


\section{CONSIDERAÇÕES FINAIS}

Boa parte das instituições de ensino continua na procura de ações que minimizem o conflitante processo das relações interpessoais existentes nos estudantes, influenciando no desempenho escolar e na convivência com outros sujeitos da comunidade - professores, funcionários e direção. Desta forma a pesquisa procurou identificar os valores pessoais de estudantes e desenvolver um processo de formação de valores autotranscendentes na tentativa de melhorar o convívio social entre eles.

Essa temática é tratada em várias literaturas abordando temas como a (in)disciplina e violência escolar, mas pouco explorada no olhar dos valores pessoais. Este trabalho contribui com indicativos e possibilidades de vivências com os sujeitos, em ações que busquem mudanças nas suas relações. Os caminhos a percorrer requerem dedicação, perseverança, paciência e afeto no trato com os estudantes, pois, a pesquisa mostrou que estes acreditam nos valores transmitidos pelos professores em sala de aula, como o respeito, educação e amor. Porém, fica uma indagação para estudos futuros: por que a escola pressente que as relações entre estudantes e professores continuam conflituosas se os valores que os estudantes consideram importantes para se viverem bem hoje, são semelhantes aos que eles percebem que os professores transmitem em sala de aula?

Outra contribuição recai nas práticas das dinâmicas cooperativas, como uma ferramenta didática, facilitando a transmissão de conteúdos, permitindo nos estudantes maior participação, aceitação, interação, vivência e reflexão. Desta forma, a pesquisa atingiu seu objetivo demonstrando que intervenções pedagógicas com dinâmicas cooperativas buscam promover mudanças de comportamentos e atitudes nos estudantes, possibilitando, nas vivências, a formação de novos valores autotranscendentes. Boa parte dos estudantes nesta etapa de ensino fundamental está potencialmente preparada para perceber quais valores são significativos para sua vida. A construção de novas relações é fruto da participação no grupo e na capacidade de respeitar as diferenças individuais. 
A pesquisa confirmou que o modelo teórico da Teoria de Valores de Schwartz valida o modelo empírico. A estrutura teórica se manteve, ratificando a eficácia na sua aplicação com estes sujeitos. A Teoria de Schwartz permitiu compreender melhor a relação entre valores, possibilitando mudanças nas atitudes e comportamentos, "uma vez que estes não são guiados por um valor particular, mas podem implicar simultaneamente diferentes valores" (PATO, 2011b, p. 301). Na afirmativa da autora, o estudo de valores sinalizou que os sujeitos buscam mais a igualdade entre eles; que estão mais dispostos a ouvir as outras pessoas; que estão mais comprometidos com os laços de amizade; que suas auto-estimas melhoraram; que procuram a diversão como prazer pessoal; e que buscam respeitar as regras e normas.

Quanto às intervenções pedagógicas - IPO - ficou notório, pela fala dos sujeitos, a necessidade da continuidade dessas atividades, inclusive, incluindo-as nos componentes curriculares, pois, valores e regras também são transmitidos pelos professores, pelos livros didáticos, pelos comportamentos dos próprios estudantes, conforme indicam os PCN (1997c), e que devem receber um tratamento explícito sendo objeto de reflexão da escola como um todo, incluindo com mais freqüência, o tema Ética na Educação. Corroborando com essas orientações nos PCN, proponho aos professores que tentem aproximar-se dos estudantes para conhecê-los e entendê-los melhor. Que a direção possa propiciar espaços de diálogos para e com os estudantes, construindo momentos de reflexão, ouvindo suas mensagens e esclarecendo decisões no coletivo. Propor que o(a)s coordenadore(a)s pedagógico(a)s possam auxiliar o corpo docente na fomentação e incentivo a que essas atividades alcancem um contentamento pedagógico. Finalizando, mas não concluindo, que dinâmicas cooperativas envolvendo valores humanos possam transitar por todo o período letivo e não apenas em momentos fragmentados do processo educativo.

Este trabalho encontrou na Ecologia Humana e Educação Ambiental o suporte necessário para a apreensão e compreensão nos cuidados com o indivíduo, com o coletivo e suas relações, permitindo "ressignificar os conceitos de cidadania, sustentabilildade, qualidade de vida, liberdade, democracia, valores humanos e vivências, influenciando na construção do sujeito ecológico, (...) e sobre a escola 
como espaço socioambiental de construção do conhecimento e produção de sentidos" (CATALÃO, MOURÃO, PATO, 2009), durante as dinâmicas trabalhadas e mensagens transmitidas pelas IPO;

A busca pela formação de valores autotranscendentes nos estudantes vai além das possíveis mudanças em seus conflitos interpessoais. Procura construir valores para que estes sujeitos possam como exemplos, aceitar e refletir sobre o sentido de uma coleta seletiva de resíduos atribuindo sentidos a esta ação como prática cotidiana (CATALÃO, ARAÚJO e ZANETI, 2011); para que eles também tenham foco nas mudanças de comportamentos associados à internalização de novos valores sobre a relação entre sociedade e natureza, inspirando-se no ideário do projeto de extensão universitária "Esperança Verde na FUP/UNB: um campus universitário modelo em gestão ambiental" (LAYRARGUES, et al, 2011), visando criar condições culturais e políticas para a implantação de um sistema de gestão ambiental universitária, neste caso, a gestão escolar; para servir de alerta à publicidade abusiva (MMA/MEC/IDEC, 2005, p. 139) que explora a fragilidade de uma personalidade em formação, incitando o medo, a violência ou qualquer comportamento prejudicial à saúde, à segurança e ao meio ambiente, resultando num prejuízo moral; para auxiliar na tomada de decisões quanto ao consumismo que se manifesta entre valores éticos, escolhas políticas e visões sobre a natureza (MMA/MEC/IDEC, 2005, p.14); e para fortalecer a importância de garantir "padrões ambientais adequados e estimular uma crescente consciência ambiental, centrada no exercício da cidadania e na formulação de valores éticos e morais, individuais e coletivos, numa perspectiva orientada para o desenvolvimento sustentável" (JACOBI, 1998).

Este trabalho contribui para o fortalecimento de ações e práticas na formação de valores pessoais em estudantes, por meio de oficinas, vislumbrando o ideário do sujeito ecológico nas relações sociais e culturais, tendo como esteio os conhecimentos epistemológicos da Ecologia Humana e Educação Ambiental. 


\section{REFERÊNCIAS}

ABBUD, Maria L. M. Contribuições da história na formação e atuação de professores para o entendimento da questão da indisciplina e violência na escola. . In: HENNING, Leoni M. P. e ABBUD, Maria L. M. (orgs). Violência, Indisciplina e educação. Londrina: Eduel, 2010.

ABRAMOVAY, Miriam (coord). Escolas inovadoras: experiências bem-sucedidas em escolas públicas. Brasília: UNESCO, Ministério da Educação. 2004.

ANTUNES, Celso. Professores e professauros: reflexões sobre a aula e práticas pedagógicas diversas. $3^{\mathrm{a}}$ ed. Petrópolis, RJ: Vozes, 2009.

ANTUNES, Celso. (In)Disciplina e (Des)Motivação. São Paulo: Paulus, 2012 (Coleção Didática, vol. 3)

AQUINO, Júlio G. A violência escolar e a crise da autoridade docente. Cadernos Cedes, ano XIX, no 47, 1998.

AQUINO, Júlio G. As transgressões da ordem escolar. In: HENNING, Leoni M. P. e ABBUD, Maria L. M. (orgs). Violência, Indisciplina e educação. Londrina: Eduel, 2010.

BARDIN, Laurence. Analise de Conteúdo. Tradução: Luis Antero Reto e Augusto Pinheiro. São Paulo: Edições 70, 2011.

BILSKY, Wolfgang. A estrutura de valores: sua estabilidade para além de instrumentos, teorias, idade e culturas. Revista de Administração Mackenzie, v. 10, no 3. São Paulo, maio/junho, 2009. Disponível em: <http://redalyc.uaemex.mx/src/inicio/ArtPdfRed.jsp?iCve=195416857003> Acesso: 20 de junho de 2014. 
BORGES, Dâmaris S. C. e MATURANO, Edna M. Alfabetização em valores humanos: um método para o ensino de habilidades sociais. São Paulo: Summus, 2012.

BRASIL, Ministério da Educação. Lei de Diretrizes e Bases da Educação Nacional. Lei $n^{0} 9.394$ de 20 de dezembro de 1996. Disponível em <http://portal.mec.gov.br/arquivos/pdf/ldb.pdf>Acesso: 25 de dezembro de 2014.

BRASIL,Ministério da Educação. Secretaria de Educação Fundamental. Parâmetros curriculares nacionais: introdução aos parâmetros curriculares nacionais, vol. 1. Brasília: MEC/SEF, 1997a. Disponível em $<$ http://portal.mec.gov.br/seb/arquivos/pdf/livro01.pdf>Acesso: 25 de dezembro de 2014.

BRASIL, Ministério da Educação. Secretaria de Educação Fundamental. Parâmetros curriculares nacionais: meio ambiente e saúde, vol. 9. Brasília: MEC/SEF, 1997b. Disponível em <http://portal.mec.gov.br/seb/arquivos/pdf/livro09.pdf>Acesso: 25 de dezembro de 2014.

BRASIL, Ministério da Educação. Secretaria de Educação Fundamental. Parâmetros curriculares nacionais: ética, vol. 8. Brasília: MEC/SEF, 1997c. Disponível em $<$ http://portal.mec.gov.br/seb/arquivos/pdf/livro01.pdf>Acesso: 30 de dezembro de 2014.

BRASIL, Ministério do Meio Ambiente-MMA, Ministério da Educação-MEC, Instituto Brasileiro de Defesa do Consumidor- IDEC.. Consumo Sustentável: Manual de educação. Brasília: Consumers International, MMA/MEC/IDEC, 2005. 160 p.

CARVALHO, Isabel C. M. Em direção ao mudo da vida: interdisciplinaridade e educação ambiental / Conceitos para se fazer educação ambiental. Brasília: IPÊ Instituto de Pesquisas Ecológicas, 1998. Cadernos de educação ambiental2. 
CARVALHO, Isabel C. M. Ambientalismo e juventude: o sujeito ecológico e o horizonte da ação política contemporânea. In: NOVAES, Regina e VANNUCHI, Paulo (orgs). Juventude e sociedade; trabalho, educação, cultura e participação. Fundação Perseu Abramo e Instituto da Cidadania, São Paulo, 2004.

CARVALHO, Isabel C. M. O sujeito ecológico: a formação de novas identidades culturais e a escola. In: MELLO, Soraia S.; TRAJBER, Rachel (orgs). Vamos cuidar do Brasil: conceitos e práticas em educação ambiental na escola. Brasília: Ministério da Educação, Coordenação Geral de Educação Ambiental: Ministério do Meio Ambiente, Departamento de Educação Ambiental: UNESCO, 2007.

CARVALHO, Isabel C. M. e STEIL, Carlos A. O habitus ecológico e a educação da percepção: fundamentos antropológicos para a educação ambiental. Revista Educação e Realidade, 34(3), p. 81 - 94 , set./dez., 2009.

CARVALHO, Isabel C. M. Educação ambiental: a formação do sujeito ecológico. 5a . ed. São Paulo: Cortez, 2011.

CARVALHO, Isabel C. M. O sujeito ecológico: a formação de novas identidades e a escola. In: PERNAMBUCO, Marta; PAIVA, Irene. (Org.). Práticas coletivas na escola. 1a. ed. Campinas: Mercado de Letras, 2013, v. 1. p 115-124. Disponível em http://www.isabelcarvalho.blog.br/wp-content/uploads/2009/05/O-sujeitoecol\%C3\%B3gico-forma\%C3\%A7\%C3\%A3o-de-identidades-culturais-e-aescola.pdf> Acesso em 26 de dezembro de 2014.

CARVALHO, Mirelly Gabrielly Mendes de.; SILVA JUNIOR, Milton Gonçalves da. Análise datransversalidade da educação ambiental na fase II do ensino fundamental da rede pública municipal e estadual de Goiânia-GO. Revista Eletrônica de Educação da Faculdade Araguaia, 5: p.1-13, 2014.

CATALÃO, Vera; MOURÃO, Laís; PATO, Claudia. Educação e Ecologia Humana: uma epistemologia para a Educação Ambiental. Revista Ambiente \& Educação, vol. 14(2). 2009. 
CATALÃO, Vera; ARAÚJO, Camylla P; ZANETI, Izabel C. B. Educação Ambiental e coleta seletiva de resíduos: um encontro de saberes nos campi da Universidade de Brasília. In: CATALÃO, Vera; LAYRARGUES, Philippe; ZANETI, Izabel C. B.(orgs.) Universidade para o século XXI: educação e gestão ambiental na Universidade de Brasília. Brasília: Cidade Gráfica e Editora, 2011. 340 p.; 22 cm.

COELHO, Jorge A P; GOUVEIA, Valdiney V.; MILFONT, Taciano L. Valores Humanos como explicadores de atitudes ambientais e intenção de comportamento pró-ambiental. Revista Psicologia em Estudo. Maringá, v. 11, n. 1, p. 199 a 207, janeiro a abril de 2006.

CORDEIRO, Luciana P. O desenvolvimento do ser humano na sua inteireza: uma proposta educativa possível. 2000. Disponível em <http://www.portalanpedsul.com.br/admin/uploads/2006/Formacao_do_Professor/Tra balho/05_05_21_PA035.pdf> Acesso em 06 de fevereiro de 2015.

CORRAL-VERDUGO, Victor. Sustentabilidad y psicologia positiva: una Visión Optimista de lãs Conductas Pro-ambientales y Pro-sociales. 2001.

CORRÊA, Rosângela Azevedo. Cultura, educação para, sobre e na paz. In: MILANI, Feizi M.; JESUS, Rita de Cássia D. P. (Orgs.) Cultura da paz: estratégias, mapas e bússolas. Salvador: INPAZ, 2003, PP. 97-141.

CORRÊA, Rosângela Azevedo. Educação para a paz: uma proposta de resolução de conflitos. Secretaria de Estado de Educação do Distrito Federal, Governo do Distrito Federal. Brasília, setembro de 2011.

CostA, Marília R. M. Valores e práticas no dia-a-dia da sala de aula. Rio de Janeiro: Wak editora, 2006. 
CRESWELL, John W. Projeto de pesquisa: métodos qualitativos, quantitativos e misto. Tradução: Magda Lopes. 3a . ed. Porto Alegre: Artmed, 2010.

DANSA, Claudia; PATO, Claudia; CORRÊA, Rosângela. Educação ambiental e ecologia humana: contribuições para um debate. Texto extraído do curso "Alfabetização ecológica: ABCERRADO", pela Faculdade de Educação-Universidade de Brasília, ofertado na modalidade On Line, pela UNB/MEC, sob a coordenação geral da profa. Rosângela Corrêa, 2014.

DAYRELL, Juarez. et al. Juventude e Escola. In: SPOSITO, Marília P. (org.) O Estado da Arte sobre juventude na pós-graduação brasileira: Educação, Ciências Sociais e Serviço Social (1999-2006). Vol. 1. Belo Horizonte, MG. Ed. Argvmentvm, 2009.

DELORS, Jacques, et al. Educação: um tesouro a descobrir: Relatório para a UNESCO da Comissão Internacional sobre Educação para o Século XXI. Trad. Guilherme João de F. Teixeira. Título original: Learning: the treasure within; report to UNESCO of the International Commission on Education for the Twentyfirst Century (highlights) (Paris: UNESCO, 1996). Brasília: UNESCO no Brasil., 2010. Disponível em <http://unesdoc.unesco.org/images/0010/001095/109590por.pdf> Acesso em 01 de fevereiro de 2015.

DIMENSTEIN, Gilberto. O cidadão de papel: a infância, a adolescência e os Direitos Humanos no Brasil. São Paulo: Ed. Ática, 1998.

GADOTTI, Moacir. Projeto político-pedagógico da escola cidadã. In: Salto para o futuro: construindo e escola cidadã, projeto político-pedagógico. Secretaria de Educação à Distância. Série de Estudos. Brasília: Ministério da Educação e do Desporto, SEED, 1998a. 
GADOTTI, Moacir e ROMÃO José E. Escola cidadã: a hora da sociedade. In: Salto para o futuro: construindo e escola cidadã, projeto político-pedagógico. Secretaria de Educação à Distância. Série de Estudos. Brasília: Ministério da Educação e do Desporto, SEED, 1998b.

GADOTTI, Moacir. Pedagogia da terra: Ecopedagogia e educação sustentável. 2000. Disponível em: <http://biblioteca.clacso.edu.ar/ar/libros/torres/gadotti.pdf> Acesso em: 17 de setembro de 2012.

GADOTTI, Moacir. Qualidade na educação: uma nova abordagem. Texto extraído do Congresso de Educação Básica: qualidade na aprendizagem (COEB-2013), realizado pela Rede Municipal de Ensino de Florianópolis, SC, 2013. Disponível em <http://www.pmf.sc.gov.br/arquivos/arquivos/pdf/14_02_2013_16.22.16.85d3681692 786726aa2c7daa4389040f.pdf> Acesso em 03 de fevereiro de 2015.

GAUDIANO, Edgar G. e KATRA, Lyle F. Valores e educação ambiental: aproximações teóricas em um campo em contínua construção. Revista Educação e Realidade. (34)3, p. 41-65, set./dez. 2009.

GIL, Antonio C. Estudo de caso: fundamentação científica, subsídios para coleta e análise de dados, como redigir o relatório. São Paulo: Atlas, 2009.

GIORDAN, Miriane Z. e GALLI, Vanilda B. Educação Ambiental um eixo norteador na mudança de comportamento. X ANPED SUL. Florianópolis, out./ 2014. Disponível em <http://xanpedsul.faed.udesc.br/arq_pdf/191-1.pdf>. Acesso em 06 de fevereiro de 2015.

JACOBI, Pedro Roberto. Educação e cidadania. In: CASCINO, Fábio; OLIVEIRA, José Flávio; JACOBI, Pedro.(orgs.). Educação, meio ambiente e cidadania: reflexões e experiências. Governo do Estado de São Paulo. Secretaria do Meio Ambiente. Coordenadoria de Educação Ambiental. São Paulo, 1998.

JALALI, Vahideh R. R. (org.) Estudos para a paz. Revisores: MSc. Maria Roseneide S. dos Santos e MSc. Mary Jane Dias. Aracaju: Editora Criação, 2010. 374 p. 
LAYRARGUES, Philippe P; LIPAI, Eneida M.; PEDRO, Viviane V. Educação Ambiental na escola: ta na lei. In: MELLO, Soraia S.; TRAJBER, Rachel. (orgs.) Vamos cuidar do Brasil: conceitos e práticas em educação ambiental na escola. Ministério da Educação, Coordenação Geral de Educação Ambiental. Ministério do Meio Ambiente, Departamento de Educação Ambiental. UNESCO, 2007.

LAYRARGUES, Philippe P. et al. Diagnósticos de percepção ambiental: o que pensam os alunos da Faculdade UnB Planaltina sobre gestão ambiental e sustentabilidade universitária. In: CATALÃO, Vera; LAYRARGUES, Philippe; ZANETI, Izabel C. B.(orgs.) Universidade para o século XXI: educação e gestão ambiental na Universidade de Brasília. Brasília: Cidade Gráfica e Editora, 2011. 340 p.; $22 \mathrm{~cm}$.

MARQUES, Maria H. Como educar bons valores: desafios e caminhos para trilhar uma educação de valor. São Paulo: Paulus, 2012. Coleção pedagogia e educação.

MANSOLDO, Ana. Educação ambiental na perspectiva da ecologia integral: Como educar neste mundo em desequilíbrio? Belo Horizonte: Autêntica Editora, 2012.

MEDEIROS, Maria Osanette. Tecendo a teia das relações na reconstrução do currículo: uma proposta metodológica. Dissertação de Mestrado em Educação. Universidade de Brasília, Faculdade de Educação, Orientadora: Laís Mourão Sá, 1995.

MENDONÇA, Rita. Educação Ambiental Vivencial. In: Encontros e caminhos: formação de educadoras(es) ambientais e coletivos educadores. Vol. 2. Brasília. Ministério do Meio Ambiente. Diretoria de Educação Ambiental. 2007.

MORAES, Maria Cândida. Pensamento eco-sistêmico: educação, aprendizagem e cidadania no século XXI. 2ª . ed. - Petrópolis, Rio de Janeiro: Vozes, 2008. 
NEPOMUCENO, Marcelo V. Relações entre valores pessoais e atitudes frente a produtos bancários. Trabalho de Dissertação pelo Instituto de Psicologia da Universidade de Brasília. Orientador Prof. Dr. Álvaro Tamayo. 2007.

PATO, Claudia e TAMAYO, Álvaro. Os valores como preditores de atitudes e comportamentos: contribuições para um debate. Revista Linhas Críticas, UNB: Brasília, v. 8 , no 14 , janeiro/junho, 2002.

PATO, Claudia. Comportamento ecológico: relações com valores pessoais e crenças ambientais. Tese de Doutorado. Universidade de Brasília. Instituto de Psicologia. 2004.

PATO, Claudia. Comportamento ecológico. In: CAVALCANTE, Sylvia e ELALI, Gleice A . (orgs) Temas básicos em Psicologia Ambiental. Petrópolis, RJ : Vozes, $2011 \mathrm{a}$.

PATO, Claudia. Valores ecológicos. In: CAVALCANTE, Sylvia e ELALI, Gleice A . (orgs) Temas básicos em Psicologia Ambiental. Petrópolis, RJ : Vozes, 2011 b.

PIZZIMENTI, Cris. Trabalhando valores em sala de aula: histórias para rodas de conversa: educação infantil, ensino fundamental I e II, ensino médio. Petrópolis, RJ: Vozes, 2013.

POZATTI, Mauro Luiz. Revista Educação e Realidade. Porto Alegre, v. 37, n.1, p. 143-159, jan./abr. 2012. Disponível em:<http://www.ufrgs.br/edu_realidade> .Acesso em 06 de dezembro de 2013.

PRONEA. Programa Nacional de Educação Ambiental. MEC, Ministério da Educação. MMA, Ministério do Meio Ambiente. Anexo 5: Tratado de Educação Ambiental para Sociedades Sustentáveis e Responsabilidade Global. 2003.

Disponível em <http://www.maternatura.org.br/servicos/biblioteca/pronea_Itima_ vers_o.pdf> Acesso em 02 de fevereiro de 2015. 
PUEBLA, Eugênia. "Educar com o coração. RJ: Ed. Fundação Petrópolis. Série Educação para a Paz. 1997. Disponível em $<$ http://colaboracomwiki.wikispaces.com/file/view/dinamicasl.pdf> Acesso em 05/03/2014.

PUIG, Josep M. e GARCíA, Xus M. As sete competências básicas para educar em valores. Rev. Valéria A Arantes. Trad. Oscar Curros. São Paulo: Summus, 2010.

RABELO, Edigleide. Maneiras criativas de ensinar - dinâmicas de grupo e jogos cooperativos para ensino fundamental I e II. $3^{\text {a }}$. edição. Rio de janeiro: Wak Editora, 2012.

RESENDE Junior, Luiz Nolasco de. Pesquisa-ação de proposta educativa lúdica pelo uso do xadrez na construção de valores por adolescentes com restrição de liberdade. Dissertação de Mestrado pela Faculdade de Educação da Universidade de Brasília, 2014.

RODRIGUES, Aroldo; ASSMAR, Eveline M. L.; JABLONSKI, Bernardo. Psicologia Social. 18 ed. reform. Petrópolis, RJ: Vozes, 2000.

ROKEACH, M. Crenças, Atitudes e Valores: uma teoria de organização e mudança. Rio de Janeiro: Ed. Interciência,1981, p.173.

SCHIFFER, Mônica B. Uma nova perspectiva na educação: valores humanos e saberes escolares. 2008. Trabalho de monografia. Disponível em http://www.pucpr.br/eventos/educere2008/anais/pdf/531_531.pdf . Acesso em 03 de fevereiro de 2015.

SCHWARTZ, S.H. Validade e aplicabilidade da Teoria de Valores. In: TAMAYO, A e PORTO, J.B. (orgs.) Valores e comportamento nas organizações. Petrópolis, RJ: Vozes. 2005.

SERRANO, Glória P. Educação em valores: como educar para a democracia. Trad. Fátima Murad. Porto Alegre: Artmed Ed. S A , 2002. 
SOUZA, Harley Anderson, et al. A importância do ensino da educação ambiental em escolas públicas da região metropolitana de Goiânia, GO. Artigo publicado no IV Congresso Brasileiro de Gestão Ambiental, pelo Instituto Brasileiro de Estudos Ambientais e Saneamento. Salvador/BA, no período de 25 a 28 de nov. 2013. Disponível em <http://www.ibeas.org.br/congresso/Trabalhos2013/VII-036.pdf> Acesso em 06 de fevereiro de 2015.

SOUZA, Juliane $M$. et al. Ecologia humana: uma reconstrução moral e ética. Resumos do V CBA - Sociedade e Natureza. Revista Brasileira de Agroecologia, outubro, 2007, v. 2, n.2. Disponível em <http://www.abaagroecologia.org.br/revistas/index.php/rbagroecologia/article/viewFile/7132/5243> Acesso em 28 de dezembro de 2014.

SPOSITO, Marília P. A instituição escolar e a violência. Cadernos de Pesquisa. Fundação Carlos Chagas, no 104, p. 58-75. São Paulo: Editora Cortez, 1998.

TAMAYO, Álvaro. Contribuições ao Estudo dos Valores Pessoais, Laborais e Organizacionais. Psicologia: Teoria e Pesquisa, Vol. 23 n. especial, p. 17-24. Brasília, 2007.

TAMAYO, Álvaro e PORTO, Juliana B. Validação do questionário de Perfis de Valores (PQV) no Brasil. Psicologia: teoria e pesquisa. Vol. 25, no 3, pp. 369-376, 2009.

UNESCO. Educação para um futuro sustentável: uma visão transdiciplinar para ações compartilhadas. Conferência Internacional sobre Meio Ambiente e Sociedade: Educação e Conscientização pública para a sustentabilidade. UNESCO. Brasília: Ed. IBAMA, 1999. $118 \mathrm{p}$.

VIANA, Rosa M. e HÖEFFEL, João L. A ecologia do amor. In: GUEVARA, José de H. et al. Conhecimento, cidadania e meio ambiente. São Paulo: Peirópolis, 1998. Séries temas transversais. v. 2. 
VIEIRA, Vanize A. M. A. e SFORNI, Marta S. F. O papel da educação escolar no Relatório Jacques Delors e nos Parâmetros Curriculares Nacionais (artigo). 2008. Disponível em <http://www.nre.seed.pr.gov.br/cianorte/arquivos/File/PEDAGOGAS/ CURRICULO/Educacao_Escolar_Marta_Sforni.pdf> Acesso em 02 de fevereiro de 2015.

VOLPATO, Rosângela A . A escola e a violência. In: HENNING, Leoni M. P. e ABBUD, Maria L. M. (orgs). Violência, Indisciplina e educação. Londrina: Eduel, 2010. 388 p. 


\section{APÊNDICES}

\section{Apêndice A - Questionário PQ21}

Queridas alunas e queridos alunos:

Estes questionários tem por objetivo colher informações para um trabalho de pesquisa de mestrado na área de educação, na Universidade de Brasília.

Nestes questionários não existem respostas certas ou erradas .... fiquem tranquilos!

Você deverá responder com o seu jeito de ver, pensar e entender algumas situações.

Não precisa escrever seu nome.

Agora, você vai ler as frases abaixo e imaginar que elas representam o comportamento de algumas pessoas.

Ao lado de cada frase você vai marcar com um "X" a única opção que indica o quanto cada comportamento dessas pessoas se parece com você.

\begin{tabular}{|c|c|c|c|c|c|c|}
\hline & & Que & $\begin{array}{l}\text { into es } \\
\text { arece }\end{array}$ & $\begin{array}{l}\text { ta pe } \\
\text { com v }\end{array}$ & $\begin{array}{l}\text { soa } \\
\text { cê? }\end{array}$ & \\
\hline & $\begin{array}{c}\text { Se } \\
\text { parece } \\
\text { muito } \\
\text { comigo }\end{array}$ & $\begin{array}{l}\text { Se } \\
\text { parece } \\
\text { comigo }\end{array}$ & $\begin{array}{l}\text { Se } \\
\text { parece } \\
\text { mais ou } \\
\text { menos } \\
\text { comigo }\end{array}$ & $\begin{array}{l}\text { Se } \\
\text { parece } \\
\text { pouco } \\
\text { comigo }\end{array}$ & $\begin{array}{l}\text { Não se } \\
\text { parece } \\
\text { comigo }\end{array}$ & $\begin{array}{c}\text { Não se } \\
\text { parece } \\
\text { nada } \\
\text { comigo }\end{array}$ \\
\hline $\begin{array}{l}\text { 1) Pensar em novas idéias e ser criativa } \\
\text { é importante para ela. Ela gosta de fazer } \\
\text { coisas de maneira própria e original. }\end{array}$ & & & & & & \\
\hline $\begin{array}{l}\text { 2) Ser rica é importante para ela. Ela } \\
\text { quer ter muito dinheiro e possuir coisas } \\
\text { caras. }\end{array}$ & & & & & & \\
\hline $\begin{array}{l}\text { 3) Ela acredita que é importante que } \\
\text { todas as pessoas do mundo sejam } \\
\text { tratadas com igualdade. Ela acredita que } \\
\text { todos deveriam ter oportunidades iguais } \\
\text { na vida. }\end{array}$ & & & & & & \\
\hline $\begin{array}{l}\text { 4) É muito importante para ela } \\
\text { demonstrar suas habilidades. Ela quer } \\
\text { que as pessoas admirem o que ela faz. }\end{array}$ & & & & & & \\
\hline $\begin{array}{l}\text { 5) É importante para ela viver em um } \\
\text { ambiente seguro. Ela evita qualquer } \\
\text { coisa que possa colocar sua segurança } \\
\text { em perigo. }\end{array}$ & & & & & & \\
\hline $\begin{array}{l}\text { 6) Ela gosta de novidade e mudança, } \\
\text { sempre tenta fazer coisas novas. É } \\
\text { importante para ela fazer várias coisas } \\
\text { diferentes na vida. }\end{array}$ & & & & & & \\
\hline
\end{tabular}




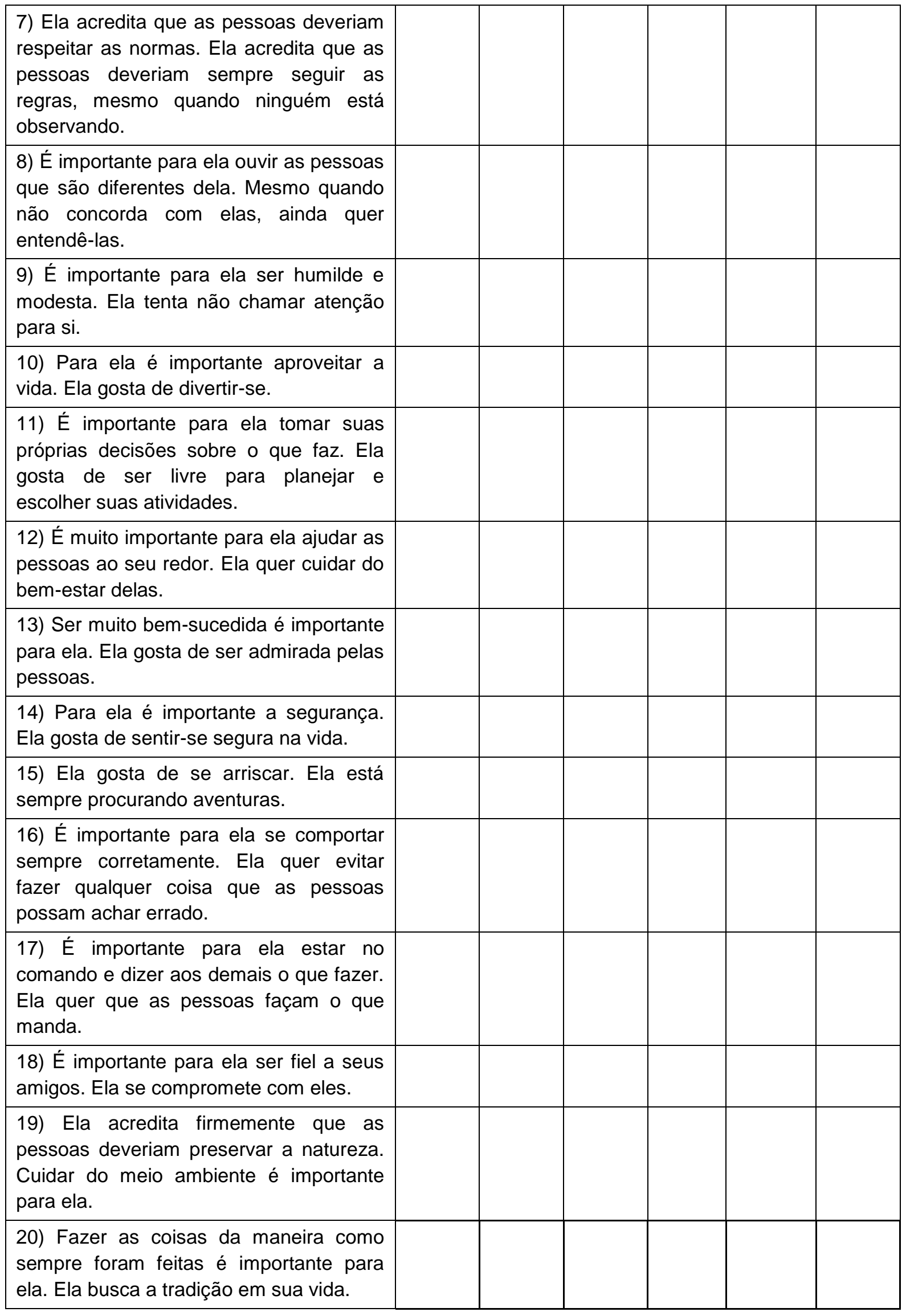


21) Ela gosta de divertir-se pelo prazer que the proporciona. Ela fica feliz em aproveitar a vida.

A seguir, você vai encontrar uma lista de frases que descrevem situações que você vive no seu dia a dia. Veja quantas vezes o que está escrito acontece com você. Procure lembrar das coisas que você faz no seu dia.

MARQUE COM UM “X” APENAS UMA OPÇÃO.

\begin{tabular}{|c|c|c|c|c|c|c|}
\hline & $\begin{array}{c}1 \\
\text { Nunca }\end{array}$ & $\begin{array}{c}2 \\
\text { Quase } \\
\text { Nunca }\end{array}$ & $\begin{array}{c}3 \\
\text { Algumas } \\
\text { vezes }\end{array}$ & $\begin{array}{c} \\
\text { Muitas } \\
\text { Vezes }\end{array}$ & $\begin{array}{c}5 \\
\text { Quase } \\
\text { Sempre }\end{array}$ & $\begin{array}{c}6 \\
\text { Sempre }\end{array}$ \\
\hline $\begin{array}{l}\text { 1) Jogo todo tipo de lixo } \\
\text { em qualquer lixeira. }\end{array}$ & & & & & & \\
\hline $\begin{array}{l}\text { 2) Providenciei uma lixeira } \\
\text { específica para cada tipo } \\
\text { de lixo em minha casa. }\end{array}$ & & & & & & \\
\hline $\begin{array}{l}\text { 3) Deixo a torneira aberta } \\
\text { durante todo o tempo do } \\
\text { banho. }\end{array}$ & & & & & & \\
\hline $\begin{array}{l}\text { 4) Evito jogar papel no } \\
\text { chão. }\end{array}$ & & & & & & \\
\hline $\begin{array}{l}\text { 6) Quando estou em casa, } \\
\text { deixo as luzes acesas em } \\
\text { ambientes que não estão } \\
\text { sendo usados. }\end{array}$ & & & & & & \\
\hline $\begin{array}{l}\text { 8) Evito desperdício dos } \\
\text { recursos naturais. }\end{array}$ & & & & & & \\
\hline $\begin{array}{l}\text { 9) Quando tenho vontade } \\
\text { de comer alguma coisa e } \\
\text { não sei o que é, abro a } \\
\text { geladeira e fico olhando o } \\
\text { que tem dentro. }\end{array}$ & & & & & & \\
\hline $\begin{array}{l}\text { 10) Ajudo a manter as ruas } \\
\text { limpas. }\end{array}$ & & & & & & \\
\hline $\begin{array}{l}\text { 11) Quando possível } \\
\text { economizo água. }\end{array}$ & & & & & & \\
\hline
\end{tabular}




\begin{tabular}{|c|c|c|c|c|c|c|}
\hline & $\begin{array}{c}1 \\
\text { Nunca }\end{array}$ & $\begin{array}{c}2 \\
\text { Quase } \\
\text { Nunca }\end{array}$ & $\begin{array}{c}\text { 3 } \\
\text { Algumas } \\
\text { vezes }\end{array}$ & $\begin{array}{c} \\
\text { Muitas } \\
\text { Vezes }\end{array}$ & $\begin{array}{c}5 \\
\text { Quase } \\
\text { Sempre }\end{array}$ & $\begin{array}{c}6 \\
\text { Sempre }\end{array}$ \\
\hline $\begin{array}{l}\text { 13) Enquanto escovo os } \\
\text { dentes, deixo a torneira } \\
\text { aberta. }\end{array}$ & & & & & & \\
\hline $\begin{array}{l}\text { 14) Separo o lixo conforme } \\
\text { o tipo (vidros, papéis, } \\
\text { materiais orgânicos, } \\
\text { plásticos). }\end{array}$ & & & & & & \\
\hline $\begin{array}{l}\text { 15) Quando não encontro } \\
\text { lixeira por perto, guardo o } \\
\text { papel que não quero mais } \\
\text { na bolsa (ou no bolso). }\end{array}$ & & & & & & \\
\hline $\begin{array}{l}\text { 17) Entrego papéis para } \\
\text { reciclagem. }\end{array}$ & & & & & & \\
\hline $\begin{array}{l}\text { 19) Quando estou tomando } \\
\text { banho, fecho a torneira } \\
\text { para me ensaboar. }\end{array}$ & & & & & & \\
\hline $\begin{array}{l}\text { 21) Colaboro com a } \\
\text { preservação da cidade } \\
\text { onde vivo. }\end{array}$ & & & & & & \\
\hline $\begin{array}{l}\text { 22) Quando não encontro } \\
\text { lixeira por perto, jogo latas } \\
\text { vazias no chão } \\
\text { (refrigerante, chá ou suco, } \\
\text { por exemplo). }\end{array}$ & & & & & & \\
\hline $\begin{array}{l}\text { 25) Apago a luz quando } \\
\text { saio de ambientes vazios. }\end{array}$ & & & & & & \\
\hline $\begin{array}{l}\text { 26) Evito desperdício de } \\
\text { energia. }\end{array}$ & & & & & & \\
\hline $\begin{array}{l}\text { 28) Quando abro a } \\
\text { geladeira já sei o que vou } \\
\text { pegar, evitando ficar com a } \\
\text { porta aberta muito tempo, } \\
\text { para não gastar energia. }\end{array}$ & & & & & & \\
\hline
\end{tabular}




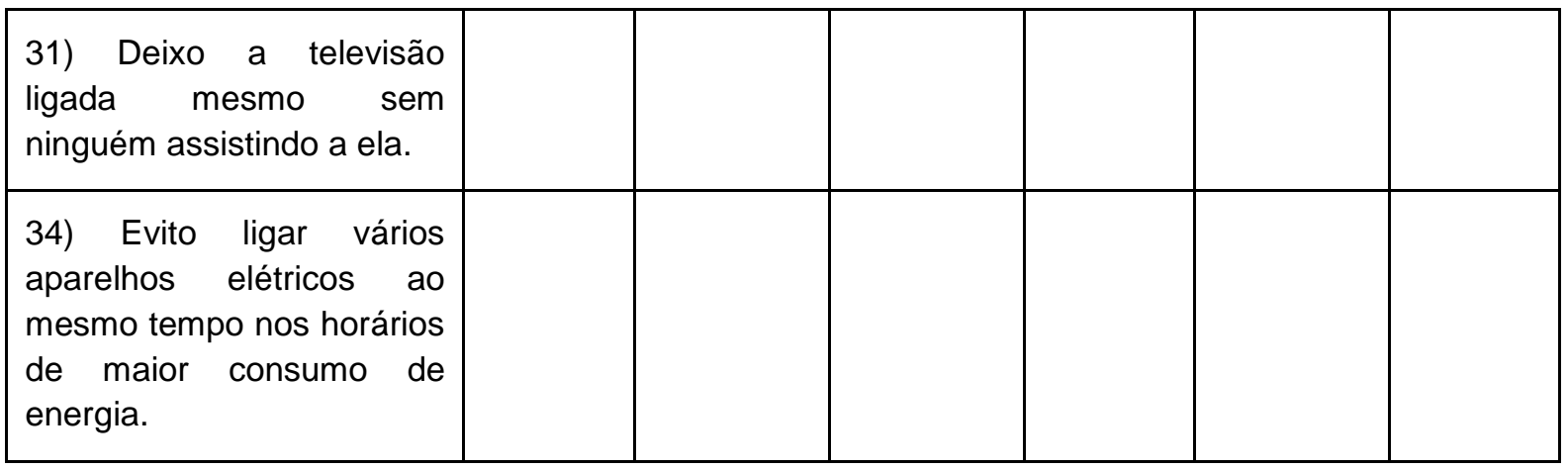

Para completar a pesquisa, responda 2 (duas) perguntas conforme seu entendimento:

1) Para você, quais são os valores que os professores transmitem durante as aulas ?

2) E quais os valores que você considera importante para viver bem hoje em dia ?

Como foi dito anteriormente, não é preciso se identificar, não tem que colocar nome, mas, por favor, preenchaas informações a seguir para terminar este trabalho:

3) Turma:

4) Período: [ ] matutino [ ] vespertino

5) Idade : anos.

6) Sexo: [ ] Feminino [ ] Masculino

Obrigado pela colaboração !

Abraços !

Prof. Luiz Lapa. 


\section{Apêndice B - Formulário de informações}

Queridas alunas e queridos alunos.

Para continuar a pesquisa, preciso da sua ajuda respondendo este pequeno questionário. Lembro que não é necessário se identificar, NÃO PRECISA COLOCAR NOME.

As informações são para entender melhor o perfil desta turma.

01. Marque as opções corretas:

Moro com ...
[ ] meus pais
[ ] só mãe
[ ] só pai
[ ] outros:
[ ] mãe e padrasto
[ ] pai e madrasta
[ ] meus avós

02. Tipo de música preferida:

03. Sobre religião:

[ ] não tenho

[ ] tenho. Minha religião é : [ ] católica

$$
\text { [ ] mulçumana [ ] outra: }
$$

Frequento aos cultos:
[ ] sempre
[ ] quase sempre
[ ] dificilmente

04. Tenho amigos ou amigas:

[ ] Não

[ ] Sim. Meu (ou minha) melhor amigo(a) é:
[ ] do colégio [ ] da rua
[ ] da família, mas não de casa
[ ] de casa
[ ] de outra cidade

05. Se DEUS desse a você o poder para resolver alguns problemas, escreva alguns problemas que você gostaria que tivessem solução:
a)
b)
c)
d)
e) 
Apêndice $C$ - Folha aplicada na dinâmica da 1a. IPO

1ํ. Momento: Responda somente a questão a seguir :

Questão 1)

O que eu mais gosto de fazer é ......

2ํ․ Momento: Após a distribuição das folhas, responda a próxima questão:

Questão 2)

Diga se você também gosta de fazer, ou não, o que está escrito na questão anterior. 


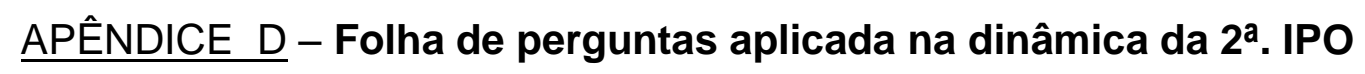

\section{Questionário}

Entrevistador(a):

Entrevistado(a):

a) O que mais te aborrece na vida?

b) O que the causa grande vontade de viver?

c) Das emoções que você sente, quais são aquelas que você não consegue controlar?

d) Se não tivesse esse seu nome, que nome escolheria para trocar?

e) Que tipo de filme você gosta de assistir?

f) Diga uma coisa que você acha que as pessoas fazem de errado. 
APÊNDICE E - Folha aplicada na dinâmica da 14a . IPO

Meu problema !!!!!!

1‥Momento:

Este é um problema que não encontro solução (ou não consigo falar a quase ninguém)

20.Momento:

Mas tenho uma solução !!! 


\section{APÊNDICE F - Folha aplicada na dinâmica da $3^{a}$. IPO}

Qualidades positivas da ALINE (cada folha com o nome de um aluno(a))

1)

2)

3)

4)

5)

6)

7)

8)

9)

10)

11)

12) 


\section{APÊNDICE G - Folha aplicada na dinâmica da 4ª IPO}

$8 \mathrm{D}-4^{\circ} . \mathrm{IPO}$

$19 / 05 / 2014$

\begin{tabular}{|l|l|l|l|}
\hline \multicolumn{1}{|c|}{ Qualidade(s) } & colega & colega & \\
\hline Legal, gente boa, & & & \\
ótima pessoa & & & \\
\hline $\begin{array}{l}\text { Engraçado(a), } \\
\text { divertido(a) }\end{array}$ & & & \\
\hline $\begin{array}{l}\text { Amigo(a), } \\
\text { companheiro(a) }\end{array}$ & & & \\
\hline Bonito(a), & & & \\
lindo(a) & & & \\
\hline Humilde & & & \\
\hline $\begin{array}{l}\text { Inteligente, cabeça, } \\
\text { reconhece erros }\end{array}$ & & & \\
\hline Sincero(a) & & & \\
\hline Puciente & & & \\
\hline
\end{tabular}




\section{ANEXOS}

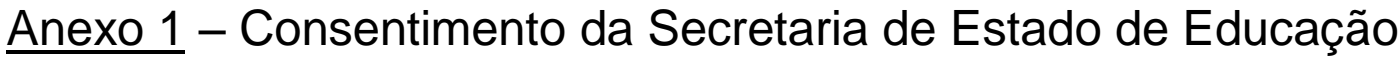

Universidade de Brasília

Faculdade de Educação

Programa de Pós Graduação em Educação

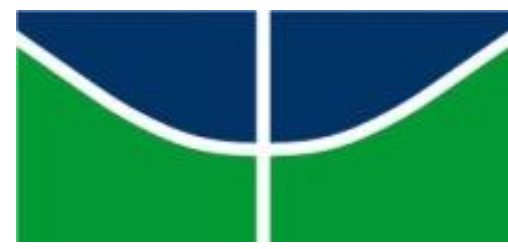

TERMO DE CONSENTIMENTO LIVRE E ESCLARECIDO

\section{À Coordenadora EDILENE MARIA NUNIZ DE ABREU NOGUEIRA}

\section{Da Coordenação Regional de Ensino de São Sebastião - CRE SS}

Eu, Luiz Gonzaga Lapa Junior, professor desta Regional de Ensino, matrícula no 58.792-3 , cursando o Mestrado do Programa de Pós Graduação da Faculdade de Educação da Universidade de Brasília - FE/UnB, no qual realizo pesquisa cujo tema é "Identificação e formação de valores pessoais no ambiente escolar de ensino fundamental II: o sujeito ecológico em construção", na Área da Educação Ambiental, tendo como orientadora a Prof ${ }^{a}$ Claudia Márcia Lyra Pato.

A referida pesquisa aborda valores humanos e ecológicos em estudantes das séries finais do ensino fundamental, razão disto, solicito autorização para atuar no Centro de Ensino Fundamental Miguel Arcanjo, durante o período letivo do ano de 2014, por meio de observações, práticas pedagógicas, registros fotográficos, filmagens, entrevistas e realização de questionários.

Esclarecemos que as informações colhidas serão utilizadas academicamente nesta pesquisa, ao mesmo tempo em que garantimos o anonimato dos sujeitos participantes. Resta comunicar que os resultados obtidos serão divulgados a esta Coordenação de Ensino, bem como à Direção do Centro de Ensino Miguel Arcanjo, caso seus responsáveis assim desejarem.

Certos de sua compreensão e colaboração, agradecemos a atenção, colocando-nos à sua disposição para quaisquer esclarecimentos a respeito deste trabalho.

Atenciosamente,

Claudia M. L. Pato

Orientadora (FE/UnB)
Luiz G. Lapa Jr. Mestrando (SEE/DF) 


\section{Anexo 2 - Permissão ao C.E.F. Miguel Arcanjo}

Universidade de Brasília

Faculdade de Educação

Programa de Pós Graduação em Educação

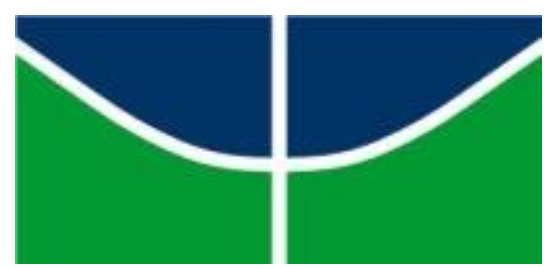

TERMO DE CONSENTIMENTO LIVRE E ESCLARECIDO

\section{À Direção do Centro de Ensino Fundamental Miguel Arcanjo}

Eu, Luiz Gonzaga Lapa Junior, professor desta Regional de Ensino, matrícula no 58.792-3 , cursando o Mestrado do Programa de Pós Graduação da Faculdade de Educação da Universidade de Brasília - FE/UnB, no qual realizo pesquisa cujo tema é "Identificação e formação de valores pessoais no ambiente escolar de ensino fundamental II: o sujeito ecológico em construção", tendo como orientadora a Prof ${ }^{a}$ Claudia Márcia Lyra Pato.

A referida pesquisa aborda valores humanos e ecológicos em estudantes das séries finais do ensino fundamental, razão disto, solicito autorização para atuar no Centro de Ensino Fundamental Miguel Arcanjo, por meio de observações, práticas pedagógicas, registros fotográficos, filmagens, entrevistas e realização de questionários.

Esclarecemos que as informações colhidas serão utilizadas academicamente nesta pesquisa, ao mesmo tempo em que garantimos o anonimato dos sujeitos participantes, podendo comunicar os resultados obtidos, a este Centro de Ensino, caso assim o desejar.

Atenciosamente,

Claudia M. L. Pato

Orientadora (FE/UnB)
Luiz G. Lapa Jr. Mestrando (SEE/DF) 


\section{Anexo 3 - Consentimento do C.E.F. Miguel Arcanjo}

\section{TERMO DE CONSENTIMENTO LIVRE E ESCLARECIDO}

A Direção do Centro de Ensino Fundamental Miguel Arcanjo, autoriza a realização da pesquisa intitulada "Identificação e formação de valores pessoais no ambiente escolar de ensino fundamental II: o sujeito ecológico em construção", pelo Profo Luiz Gonzaga Lapa Junior, matrícula ํo 58.792-3, da Secretaria de Estado de Educação do Distrito Federal, sob a orientação da Prof ${ }^{a}$ Dra. Cláudia Márcia Lyra Pato da FE/UNB, nos termos em que esta foi apresentada.

A relevância nesta pesquisa baseia-se na expectativa de mudanças nas atitudes e comportamentos no corpo discente, promovendo melhorias no trabalho pedagógico.

Outrossim, declaramos que a referida pesquisa foi apresentada ao corpo docente - matutino e vespertino - deste Centro de Ensino, no mês de março de 2014, obtendo total consentimento destes profissionais.

De acordo:

Matr.

Matr.

Diretor

Vice-Diretora

Brasília, março de 2014 